\title{
Production and Application of Synthetic Precursors Labeled with Carbon-11 and Fluorine-18
}

\author{
Richard A. Ferrieri \\ Brookhaven National Laboratory \\ Department of Chemistry \\ Upton, New York 11973-5000
}

\section{Introduction}

\section{A. General Considerations in the Design of a PET Radiotracer}

Without a doubt, the success of PET as an imaging tool for basic research in the life sciences stems largely from the effort and success of chemists over the years in developing suitable radiotracers. This success derives in part from the fact that there exists today an extensive inventory of synthetic precursors, or small molecules labeled with short-lived positron emitting radionuclides, that can be used either for attaching radioactive isotopes to suitable substrates, or used as building blocks toward constructing larger biomolecules of interest.

Since its infancy in the early $1960^{\prime}$ 's, PET has evolved into a complex science for investigating the biochemical transformations of drugs and molecules within living systems. PET radiotracer chemistry too has evolved into a complex chemical science. Now radiotracers are engineered to be highly specialized probes for targeting specific regions such as neurotransmitter receptors, or chemical substances within the living system. In some instances this targeting can be as simple as measuring bioavailability. In others, it can become a more complex process of monitoring bioactivity of that region or substance. To keep pace with this growth, chemists are no longer driven solely by certain practical aspects of precursor production such as whether the precursor can be produced in amounts of radioactivity suitable for subsequent chemistry and final radiotracer formulation to meet the PET study protocol, whether it can be produced routinely over the course of the day, whether it is chemically and isotopically pure so as not to strongly influence subsequent chemistry and/or purification, or whether its specific activity is acceptable for the nature of the PET study. Now the design aspects of radiotracers for PET place additional demands on the chemist such as which radionuclide to choose to target a specific function (this is especially true in measurements of bioactivity), what position within the radiotracer to label, or which stereoisomer to use. (Långström $e t$ al., 1989a; Långström et al., 1989b; Långström et al., 1989c) Thus special emphasis has to be placed on the development of precursors that can satisfy all of these demands, and more as time goes on.

A number of exhaustive reviews on the subject of precursor preparation have appeared in the literature over the years. (Wolf et al., 1973; Clark and Buckingham 1975; Silvester, 1976; Wolf and Redvanly, 1977; Fowler and Wolf, 1982; Ferrieri, 1983; Vaalburg and Paans, 1983; Långström et al., 1991; Fowler and Wölf, 1997) The interested reader, and especially newcomers, would certainly benefit from the insights of 
these earlier works. The scope of this chapter will encompass old, as well as the new approaches for conducting PET precursor preparation with the intent on being comprehensive without being exhaustive in the procedural descriptions. The hope, of course, is that this work provides sufficient insight as a general guide into methodologies with citations to appropriate references. It should also be noted that most of this chapter is dedicated to the subject area surrounding PET precursors labeled with carbon-11 and fluorine-18, since most of the milestones delineating biochemical transformations and movement of drugs within living systems have involved radiosyntheses using these radioisotopes.

\section{B. Short-Lived Positron Emitting Radionuclides for PET}

Without a doubt, the short-lived positron emitting radionuclides that have had the greatest impact in PET for radiotracer synthesis are carbon-11, nitrogen-13, oxygen-15 and fluorine-18. This is understandable in view of the fact that the first three of these isotopes are elements of life, and can be substituted for their stable counterparts without influencing the bioactivity of the molecule. While fluorine-18 is not a significant element in living systems, its half-life and properties makes its use in labeling of considerable value. Table 1 lists some of the physical properties of these radionuclides.

The development of any radiotracer for a PET study begins with the selection of an appropriate radionuclide. This becomes especially difficult when there exists multiple synthetic precursors that can allow chemists to produce the same, or nearly the same biomolecule, but with a different radioactive tag. One example that comes to mind is the radiolabeling of $\mathrm{N}$-methylspiroperidol for measuring dopamine $\mathrm{D}_{2}$ receptors. This labeling has been performed with fluorine-18 in a multi-step two hour synthesis starting with $\left[{ }^{18} \mathrm{~F}\right]$ fluoride (Shiue et al., 1986), as well as with carbon-11 starting with $\left[{ }^{11} \mathrm{C}\right] \mathrm{H}_{3} \mathrm{I}$. (Wagner et al., 1983) Several factors can influence one's decision in this regard. The first is whether the physical half-life of the radioisotope matches the biological half-life of the process under investigation. Perhaps more important in the decision process is the precursor's specific activity. As Table 1 reveals, theoretical specific activities for these common radionuclides are varied. On the practical side, actual precursor specific activities are significantly lower owing to sources of endogenous stable isotopes in the materials used to construct the targets, the chemical materials irradiated in order to generate the radioisotope, the transfer lines that allow the radioisotope to be manipulated between the target and laboratory, as well as in the starting materials used for subsequent synthesis. Typically, carbon-11 specific activities tend to be higher than the other isotopes (Wolf and Redvanly, 1977; Finn et al., 1984; Fowler, 1986; Dannals et al., 1991) owing to the lower amounts of endogenous stable carbon in the starting materials. Even so, it is important to realize that, since the radiotracer is not free of carrier, the specific activity is changing proportional to the radioactive decay. Thus, the time necessary to prepare the synthetic precursor, and manipulate it through the subsequent synthetic pathways, and/or purifications can weigh heavily on one's decision. Finally, the nature of the information one is seeking from the PET measurement also plays an important role in the selection of the radioisotope. Whether one is seeking spatial distribution and regional concentrations of a target substance or neurotransmitter binding or uptake site, or whether one is seeking to assess bioactivity relying on metabolitic breakdown of the tracer could impact on this selection. 


\section{General Methodologies for Producing Labeled Precursors}

Having addressed these important issues regarding the design of the radiotracer for the intended study, we now need to turn our attention to the actual stage of producing a useful synthetic precursor from what is typically a less useful source of the desired radionuclide. Historically, one can classify precursor preparation methods into those involving nonsynthetic approaches, and those involving more conventional synthetic approaches. The latter, of course, has received greater attention over the years perhaps owing to the fact that PET chemists are mostly derived from a synthetic organic chemistry background, and for whatever reasons, find greater security in developing more conventional synthetic approaches to doing things. In addition, such approaches are more readily automated as the chemical processing becomes standardized in the PET laboratory. This clearly becomes an issue when attempting to minimize radiation exposure to personnel. However, a brief discussion of nonsynthetic strategies to preparing precursors is warranted since, after all, PET's early roots in radiotracer development grew out of this area of research. Nonsynthetic approaches cover a rather broad area of radiochemistry that includes in-target or hot atom chemistry, radiation labeling, accelerated ion labeling, as well as labeling through the use of some excitation source of energy.

Between 1950 and the mid-1970's, a number of chemists studied the chemistry of these short-lived positron emitting radionuclides as they were produced within the irradiation target as high energy atoms. This field became known as Hot Atom Chemistry, and flourished for a number of years under the aegis of basic energy science. Aside from the intrinsic value of understanding the basic chemical properties of these energetic or hot atoms, there was a strong commitment to providing a basic framework of knowledge that could allow chemists to control the chemical fate of these radioactive atoms within complex chemical environments. Such action set the early stage for producing the short-lived positron emitters in chemical forms that were useful for the synthesis of complex radiotracers. (Wolf and Redvanly, 1977; Ferrieri, 1983a) Unfortunately, chemists quickly realized that to produce sufficient quantities of radioactivity necessary for clinical research and application, the chemical fate of these primary hot atom products were often compromised by the harsh radiation field. A classic example of this behavior is the production of $\mathrm{H}\left[{ }^{11} \mathrm{C}\right] \mathrm{N}$ from a gaseous target comprised of $95 \% \mathrm{~N}_{2}$ and $5 \% \mathrm{H}_{2}$. (Finn et al., 1971) The reader will later see that this is an extremely useful synthetic precursor for radiolabeling. At low irradiation doses, nucleogenic carbon- 11 atoms produced from the ${ }^{14} \mathrm{~N}(\mathrm{p}, \alpha)^{11} \mathrm{C}$ reaction will react to form $\mathrm{H}\left[{ }^{11} \mathrm{C}\right] \mathrm{N}$ as the hot atom product. However, at the higher irradiation doses necessary to provide adequate levels of carbon-11 for a PET study, the intense ionizing radiation field caused by the higher flux of incident charged particles induces radiolytic reduction of this product to a less desirable form as $\left.{ }^{[11}{ }^{11}\right]_{H}$. For the most part, the chemical form of the desired radionuclide, as it exits in the target, is usually the result of one or more physical and chemical changes occurring to the primary hot atom product, or more simply put the result of the radiation chemistry. It is interesting to note that even today, many of these phenomena are not entirely understood, but are relied on daily in the PET field for their ability to routinely produce sources of radionuclides. It is also interesting to note that chemists have had very little success at altering what goes on inside the production target, 
with the exception of a few cases, namely solid cryogenic targets, that will be discussed later under their appropriate subsections.

Radiation labeling, as it is applied outside the target confines, is another area that has not been extensively exploited in the PET field for producing radiolabeled substances. Such labeling can be facilitated by either the introduction of an external electromagnetic radiation source, or by the internal radiation accompanying radioactive decay of the nuclide. The labeling effectiveness is attributed to the charge-state and/or excitation of the reactants rather than their kinetic energy. Effective use of radiation labeling lies in designing the chemical environment such that the resultant radiolytic species are selective in their reactions leading to a single labeled product. Unfortunately, application of this approach to preparing labeled compounds has been limited to carbon14. An example of what could be accomplished with selective radiation labeling includes the preparation of $2,3-\left[{ }^{14} \mathrm{C}_{1}\right]$ propanol by exposing $\left[{ }^{14} \mathrm{C}\right]$ ethylene and methanol to a gamma source. (Oae et al. 1968)

Labeling by use of accelerated radioactive ions has also found limited application to preparing labeled compounds. (Wolf, 1960) Again, the majority of work utilizing this technique involved long-lived isotopes such as carbon-14 as ${ }^{14} \mathrm{C}^{+},\left[{ }^{14} \mathrm{C}^{+} \mathrm{O}^{+}\right.$and $\left[{ }^{14} \mathrm{C}\right] \mathrm{O}_{2}^{+}$ (Cacace et al. 1958; Pohlit et al., 1970; Lintermans et al. 1972), and tritium as $\mathrm{T}^{+}$. (Wolfgang et al., 1956)

Finally, the use of external excitation sources such as electric discharge, microwave radiation or photosensitization have found application to producing labeled compounds through formation and reaction of radioactive ions or radicals. Unlike the other methods discussed, PET chemist have been successful at utilizing some of these strategies for producing PET precursors labeled with carbon-11, nitrogen-13 and fluorine-18. Examples include the production of $\left[{ }^{11} \mathrm{C}\right]$ acetylene from $\left[{ }^{11} \mathrm{C}_{\mathrm{H}}\right.$ in an inductively coupled argon plasma (Crouzel et al. 1979), the production of [ ${ }^{13} \mathrm{~N}_{3} \mathrm{H}_{3}$ from $\left.{ }^{13} \mathrm{~N}\right]$ nitrogen gas using a microwave generated hydrogen plasma (Ferrieri, 1983b), and the production of $\left[{ }^{18} \mathrm{~F}\right]$ fluorine gas from electric anodic discharge. (Bergman et al.,1997)

\section{Precursors Labeled with Carbon-11}

\section{A. Nuclear Reactions for Producing Carbon-11}

The nuclear reaction for producing carbon-11 that has had the greatest impact to

PET has been the ${ }^{14} \mathrm{~N}(p, \alpha)^{11} \mathrm{C}$ reaction. This becomes clear for several reasons: (i) the radionculide can be produced from non-carbon material thus providing a source of high specific activity tracer; (ii) the reaction possesses a substantial nuclear cross-section of about 250 millibarns, thus affording substantial amounts of radioactivity from reasonable irradiations; and (iii) the reaction also possesses a relatively low threshold of $3.1 \mathrm{MeV}$, thus allowing production of radionuclide at reasonable particle energies. Other relevant reactions for producing carbon-11 are summarized in Table 2.

\section{B. Preparation of $\left[{ }^{11} \mathrm{C}\right]$-Labeled Oxides}

The most widely used chemical form of carbon-11 for PET radiotracer synthesis is ${ }^{11} \mathrm{C}_{2} \mathrm{O}_{2}$. Its widespread use is attributed to the fact that it can be easily harvested from 
the target gas stream either using liquid nitrogen cooled traps or even without the need for harsh cryogens using a mixture of reducing nickel catalyst and molecular sieve $5 \AA$ at ambient temeprature. In addition, virtually every synthetic carbon-11 precursor can be derived from this chemical form of carbon-11, as seen in the schematic below.

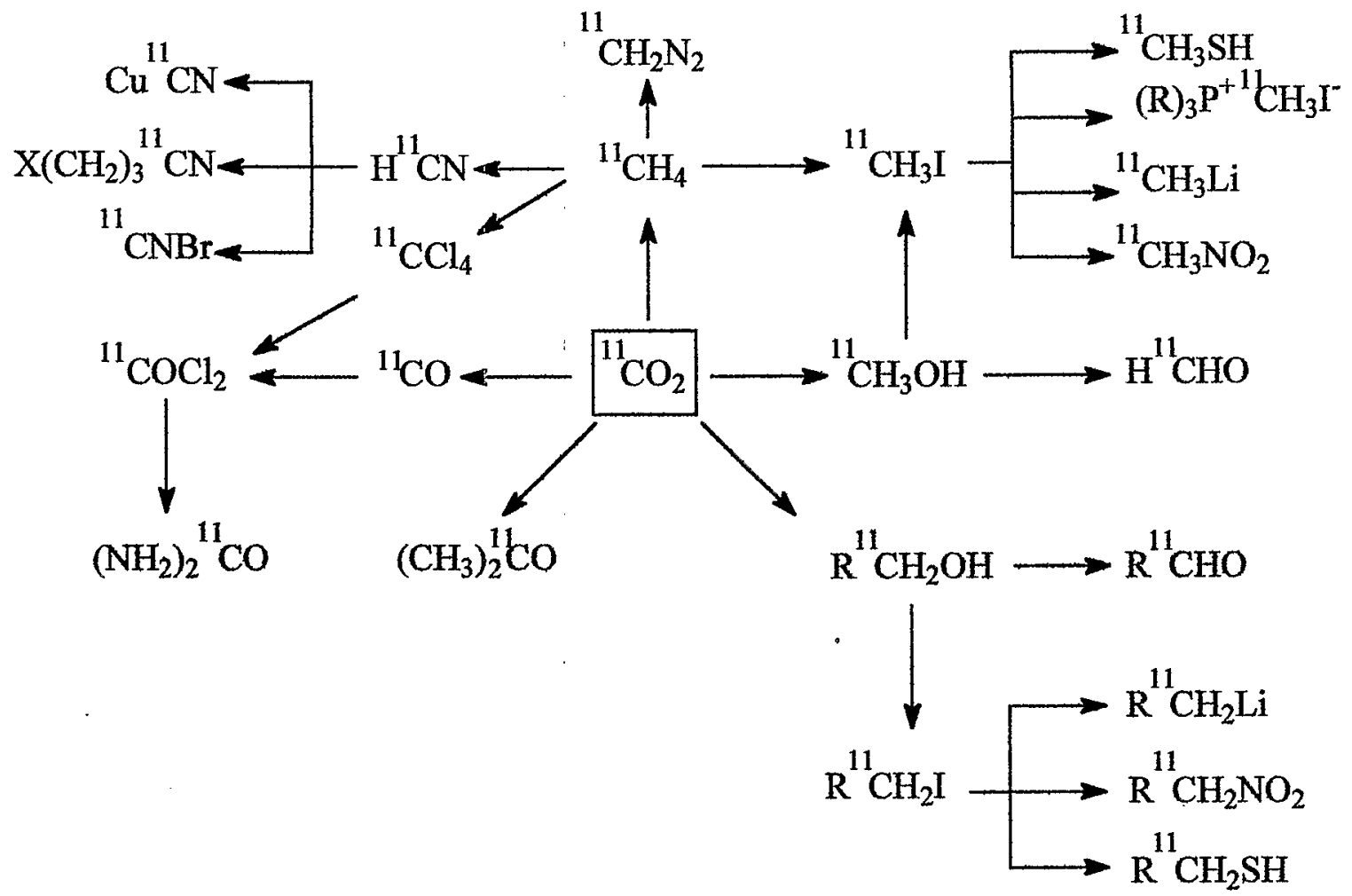

The production of $\left[{ }^{11} \mathrm{C}\right] \mathrm{O}_{2}$ can be carried out utilizing continuous-flow or batchwise irradiations of high pressure gaseous targets comprised of research grade $\mathrm{N}_{2}$ containing between 10 and $100 \mathrm{ppm}$ levels of $\mathrm{O}_{2}$. As discussed earlier with regard to intarget chemistry, $\left[{ }^{11} \mathrm{C}_{\mathrm{O}} \mathrm{O}_{2}\right.$ is not the primary product, but the result of radiolytic oxidation of $\left[{ }^{11} \mathrm{C}\right] \mathrm{N}$ radicals to $\left[{ }^{11} \mathrm{C}\right] \mathrm{O}$ and eventually $\left[{ }^{11} \mathrm{C}\right] \mathrm{O}_{2}$ under production conditions. (Christman et al., 1975)

$\left[{ }^{11} \mathrm{C}_{2} \mathrm{O}_{2}\right.$ can also be produced from the proton or deuteron irradiation of solid enriched boron-10 targets, typically in the form of boron oxides. The advantage, of course, with the enriched boron targets is the zero energy threshold making them appealing for low energy high intensity proton accelerators. Typically, particle irradiation of a boron oxide target using an appropriate inert sweep gas can yield reasonable quantities of carbon-11, distributed between the products $\left[{ }^{11} \mathrm{C}\right] \mathrm{O},\left[{ }^{11} \mathrm{C}\right] \mathrm{O}_{2}$ and $\left[{ }^{11} \mathrm{C}_{\mathrm{H}}\right.$. (Buckingham and Forse, 1963; Welch and Ter-Pergossian.,1968; Clark and Buckingham, 1971; Winstead et al., 1973; Ritchie, 1968; More and Troughton, 1972; Perris et al. 1974) These targets tend to work best with a high power density of beam focussed onto the powdered matrix that causes a "quick melt" yielding a glassy structure. Complete conversion to $\left[{ }^{11} \mathrm{C}\right] \mathrm{O}_{2}$ can be obtained by passing the target effluent gas through a copper oxide combustion furnace maintained at $800^{\circ} \mathrm{C}$.

$\left[{ }^{11} \mathrm{C}\right] \mathrm{O}$ is most often prepared through the catalytic reduction of $\left[{ }^{11} \mathrm{C}\right] \mathrm{O}_{2}$ over metallic zinc at $400^{\circ} \mathrm{C}$. (Clark and Buckingham, 1975; Welch and Ter-Pergossian, 1968) 
The zinc catalyst is most effective when dispersed on an inert support. Asbestos has worked well for this application. This reduction is typically high, but not quantitative. However, unconverted $\left[{ }^{11} \mathrm{C}_{3} \mathrm{O}_{2}\right.$ can be easily removed from the gas stream using Ascarite $^{\mathrm{TM}}$ (silica supported $\mathrm{LiOH}$ ) thus rendering the $\left[{ }^{11} \mathrm{C}\right] \mathrm{O}$ in a pure form.

Direct in-target production of usable quantities of $\left[{ }^{11} \mathrm{C}\right] \mathrm{O}$ can be prepared as well using solid boron oxide targets. As described earlier, the same particle irradiations can be carried out with the exception that hydrogen gas is used instead of an inert gas to sweep the target matrix during bombardment. (Clark and Buckingham 1975; Winstead et al., 1973) This action results in $94 \%$ yields of the desired oxide which can be purified in much the same way as described above.

\section{Preparation of $\left[{ }^{11} \mathrm{C}\right]-\mathrm{L}$ abeled Cyanides}

Carbon-11 labeled cyanide as $\mathrm{H}\left[{ }^{11} \mathrm{C}\right] \mathrm{N}$ can be an extremely useful synthetic precursor for the PET chemist for replacing halogen atoms through nucleophilic substitution with the radiolabeled cyano group. It has been used in the synthesis of labeled amines, ketones, aldehydes, acids, and amino acids. (Fowler and Wolf, 1986) Over the years, several synthetic and nonsynthetic approaches have been explored for their ability to routinely prepare useful quantities of this precursor. Only a few are notable. (Finn et al. 1971; Lamb et al., 1971)

Synthetic approaches for the preparation of $\mathrm{H}\left[{ }^{11} \mathrm{C}\right] \mathrm{N}$ rely on either $\left[{ }^{11} \mathrm{C}^{\mathrm{O}} \mathrm{O}_{2}\right.$ or ${ }^{11} \mathrm{C}_{\mathrm{H}} \mathrm{H}_{4}$ as the starting material. One of the earliest methods involved the static reaction between $\left[{ }^{11} \mathrm{C}\right] \mathrm{O}_{2}$ and potassium metal with carrier $\mathrm{NH}_{3}$. (Cramer and Kistiokosky, 1941; Loftfield , 1947; Lamb et al., 1971; Finn et al., 1971) The reaction tends to be messy requiring distillation of the precursor over sulfuric acid.

$$
{ }^{11} \mathrm{CO}_{2}+4 \mathrm{~K}+\mathrm{NH}_{3} \stackrel{620^{\circ} \mathrm{C}}{\longrightarrow} \mathrm{K}^{11} \mathrm{CN}+\mathrm{KH}+2 \mathrm{KOH}
$$

The most widespread approach for preparing $\mathrm{H}\left[{ }^{11} \mathrm{C}\right] \mathrm{N}$ involves the catalytic conversion of $\left[{ }^{11} \mathrm{C}\right] \mathrm{H}_{4}$ by reacting it with carrier $\mathrm{NH}_{3}$ over platinum metal at $1000^{\circ} \mathrm{C}$. (Christman et al., 1975; Finn et al., 1971)

$$
{ }^{11} \mathrm{CH}_{4}+\mathrm{NH}_{3} \frac{\mathrm{Pt}}{1000^{\circ} \mathrm{C}} \mathrm{H}^{11} \mathrm{CN}
$$

The conversion is typically $90 \%$ or greater for a single-pass flow reaction. The appeal of this approach is due to the fact that all the processing steps can be easily automated. Whether the chemist starts with ${ }^{11} \mathrm{CH}_{4}$ produced from the $\mathrm{N}_{2}+\mathrm{H}_{2}$ gas target, or from $\left[{ }^{11} \mathrm{C}\right] \mathrm{O}_{2}$ from the $\mathrm{N}_{2}+\mathrm{O}_{2}$ target is a matter of preference. Some believe the $\left[{ }^{11} \mathrm{C}_{\mathrm{H}} \mathrm{H}_{4}\right.$ target provides a higher specific activity precursor that would extend to subsequent chemistry. In addition, macroscopic amounts of radiolytic $\mathrm{NH}_{3}$ are produced within the $\mathrm{N}_{2}+\mathrm{H}_{2}$ target which can serve as the source of ammonia for the conversion to cyanide, thus eliminating the need to introduce an extraneous source of the gas. It should be noted, however, that trapping $\left[{ }^{11} \mathrm{C}_{\mathrm{H}} \mathrm{H}_{4}\right.$ on liquid nitrogen cooled molecular sieves can be problematic owing to the liquefaction of the target gas. Of course this is not an insurmountable problem, but it raises concern over certain safety issues. If one starts with $\left[{ }^{11} \mathrm{ClO}_{2}\right.$ it can be readily trapped at ambient temperatures using a mixture of 
reducing nickel catalyst and molecular sieve $5 \AA$. Reduction to $\left[{ }^{11} \mathrm{C} \mathrm{H}_{4}\right.$ in a hydrogen atmosphere at $365^{\circ} \mathrm{C}$ is fast and quantitative. One precautionary measure should be noted. Macroscopic amounts of nitrogen oxides will form in the gaseous $\mathrm{N}_{2}+\mathrm{O}_{2}$ targets when operated with high (>100 ppm) levels of $\mathrm{O}_{2}$. These oxides tend to trap on the nickel/molecular sieve, as well, giving rise to $\mathrm{NH}_{3}$ that can eventually poison the catalyst's reducing effectiveness. This has not been a problem for lower $\mathrm{O}_{2}$ levels.

Several non-synthetic approaches for preparing $\mathrm{H}\left[{ }^{11} \mathrm{C}\right] \mathrm{N}$ have also been explored over the years. These included direct recoil labeling from proton irradiations of solid metallic cyanide targets, solid metallic amide targets (Lamb et al., 1971; Finn et al. 1971; Christman et al. 1970), as well as from gaseous targets comprised of mixtures of $\mathrm{N}_{2}$ and $\mathrm{H}_{2}$. (Christman et al., 1975; Lamb et al., 1971; Finn et al., 1971; Christman et al., 1970)

$$
\begin{array}{ll}
\mathrm{NaCN} & \frac{{ }^{14} \mathrm{~N}(\mathrm{p}, \alpha)^{11} \mathrm{C}}{{ }^{12} \mathrm{C}(\mathrm{p}, \mathrm{pn})^{11} \mathrm{C}} \rightarrow \mathrm{Na}^{11} \mathrm{CN} \\
\mathrm{LiNH}_{2} & \frac{{ }^{14} \mathrm{~N}(\mathrm{p}, \alpha)^{11} \mathrm{C}}{\mathrm{H}_{2} \mathrm{O}} \rightarrow \mathrm{H}^{11} \mathrm{CN}+\mathrm{NH}_{3}
\end{array}
$$

While the NaCN target produces large amounts of carbon-11, there is an obvious constraint in the precursor's specific activity that hampers its use for PET. Recoil synthesis from $\mathrm{LiNH}_{2}$ is not any better owing to the low $3.6 \%$ yield of $\left[{ }^{11} \mathrm{C}\right]$ cyanide extracted. Gas targets comprised of $5 \% \mathrm{H}_{2}$ and $95 \% \mathrm{~N}_{2}\left(\mathrm{O}_{2}\right.$ free) will also produce about a $50 \%$ yield of $\mathrm{H}\left[{ }^{11} \mathrm{C}\right] \mathrm{N}$, with the remainder of the carbon 11 activity present as $\left[{ }^{11} \mathrm{C}^{\mathrm{H}} \mathrm{H}_{4}\right.$.

$$
\begin{aligned}
& \left.{ }^{11} \mathrm{C}^{*}+\mathrm{N}_{2} \longrightarrow{ }^{11} \mathrm{C}-\mathrm{N}=\mathrm{N}\right]^{*} \\
& \left.\left.{ }^{11} \mathrm{C}-\mathrm{N}=\mathrm{N}\right]^{*} \longrightarrow{ }^{11} \mathrm{CN}\right]+\mathrm{N} \\
& \left.{ }^{11} \mathrm{CN}\right]+\mathrm{H}_{2} \longrightarrow \mathrm{H}^{11} \mathrm{CN}+\mathrm{H} \\
& \mathrm{H}^{11} \mathrm{CN}+\mathrm{nH}_{2} \text { - } 11 \mathrm{num}-{ }^{11} \mathrm{CH}_{4}
\end{aligned}
$$

Unfortunately, this method is not practical in that the product distribution is only reproducible at low irradiation doses where microcurie levels of the precursor are generated. Once higher irradiation doses are applied $\left(>1 \mathrm{eV} \cdot \mathrm{molecule} \mathrm{e}^{-1} \cdot \mathrm{sec}^{-1}\right)$ to the target gas, near quantitative radiolytic reduction of the $\mathrm{H}\left[{ }^{11} \mathrm{C}\right] \mathrm{N}$ to $\left[{ }^{11} \mathrm{C}\right] \mathrm{H}_{4}$ occurs thus requiring synthetic intervention in a post-irradiation treatment. More recently, cryogenic solid ammonia targets were investigated as a source for recoil labeling, and found to produce reasonable amounts of $\mathrm{H}\left[{ }^{11} \mathrm{C}\right] \mathrm{N}(30-40 \%$ of theoretical) even for high dose irradiations. (Firouzbakht et al., 1999a) A comparison of quartz and silver target materials revealed that the silver target was less sensitive to applied dose relative to carbon- 11 recovery as cyanide.

Transition-mediated $\left[{ }^{11} \mathrm{C}\right]$-cyanation of aryl rings is also noteworthy as a means to introduce carbon-11 into larger molecules. The usefulness of the technique was first 
realized using tricarbonylchromium complexes (Balatoni et al., 1989) and later with tetrakis(triphenylphosphine)palladium(0). (Andersson and Långström, 1994) These catalysts required special handling in order to exclude oxygen and water. More recently, it was demonstrated that copper(I) salts will mediate a vast number of aromatic nucleophilic substitutions using $\left.{ }^{11} \mathrm{C}\right] \mathrm{N}$. (Ponchant et al., 1997) The copper salts have the advantage in that they don't suffer the instability problems of the chromium or palladium catalysts. In addition, much of the chemistry generating the $\left[{ }^{11} \mathrm{C}\right]$ aryl nitriles, and their subsequent conversion to other functional groups can be carried out as single-pot reactions.

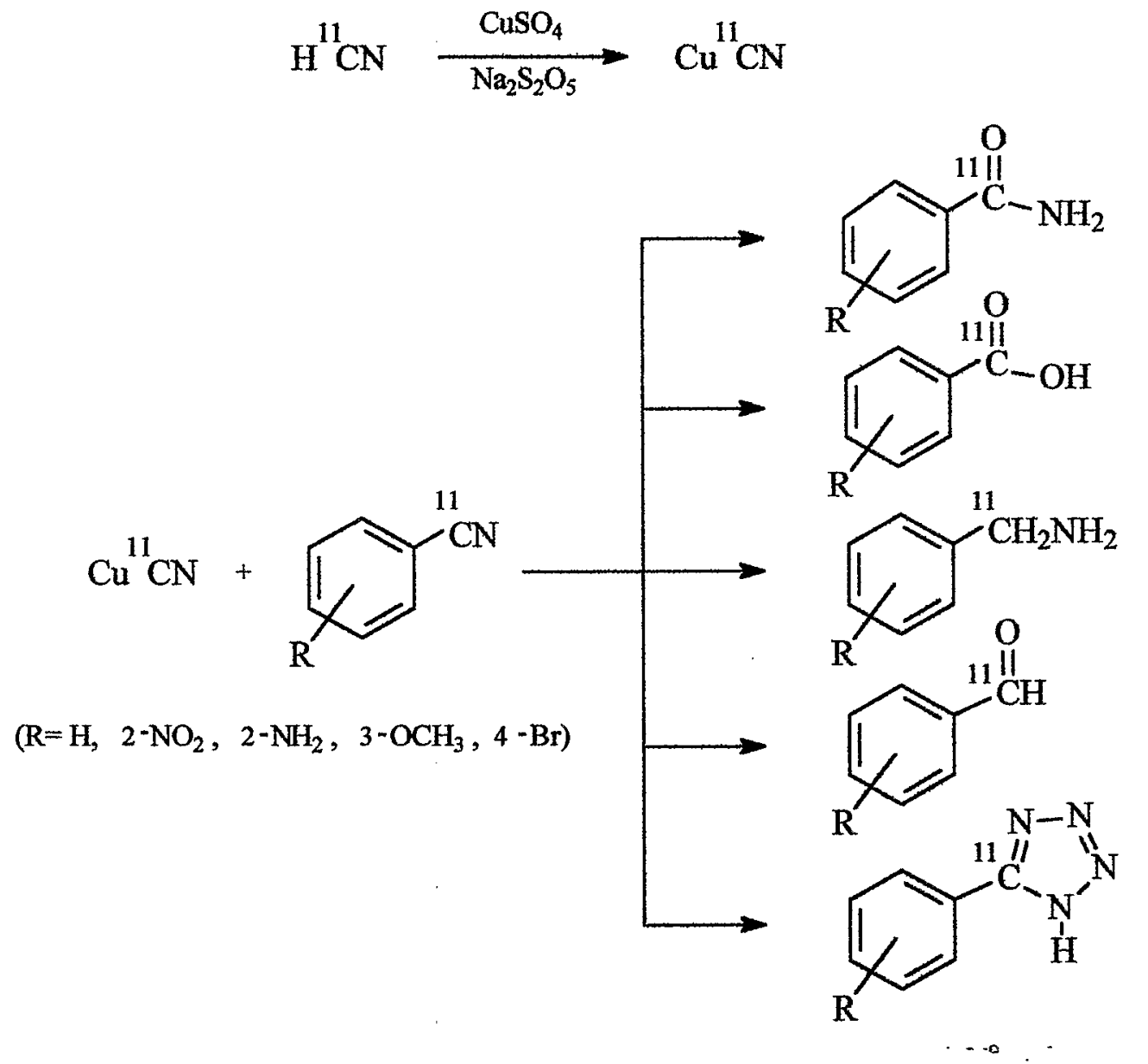

Within the context of this section it is worth noting how one can introduce other functional groups into the labeled cyanide precursor thus producing a new line of precursors with multifunctional properties that can serve to increase the diversity of molecular structures possible for rapid labeling synthesis. For example, substitution between $\left[{ }^{11} \mathrm{C}\right] \mathrm{N}$ and corresponding dibromo-, diiodo- and ditosyl- compounds using Kryptofix 2.2 .2 as an anion activator will produce $80-95 \%$ yields of the corresponding radiolabeled halonitriles. 


$$
\begin{gathered}
\mathrm{X}-\left(\mathrm{CH}_{2}\right) \mathrm{n}-\mathrm{Y}+{ }^{11} \mathrm{CN}-\frac{\mathrm{K}-2 \cdot 2 \cdot 2 \cdot / \mathrm{K}^{+}}{\mathrm{X}, \mathrm{Y}=\mathrm{I}, \mathrm{Br}, \text { tosyl }} \\
\mathrm{n}=2.3,4
\end{gathered}
$$

In one example cited, 4-iodobutyro $\left[\mathrm{CN}^{11} \mathrm{C}\right]$ nitrile was used to alkylate an achiral glycine derivative producing DL-[6- ${ }^{11}$ C]lysine. (Antoni et al., 1989) In yet another example, $\left[\mathrm{CN}-{ }^{11} \mathrm{C}\right]$ acrylonitrile can be prepared in $35 \%$ yields from the substitution reaction between [ $\left.{ }^{11} \mathrm{C}\right] \mathrm{N}^{\top}$ and vinylbromide catalysed by tetrakis(triphenylphosphine)palladium. (Antoni et al. 1991)

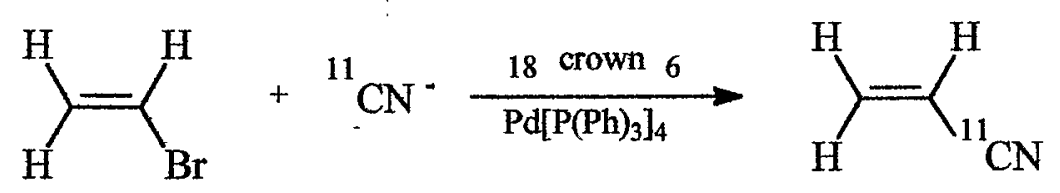

This precursor affords the synthetic opportunity to introduce a radiolabeled cyanoethyl group into a larger molecule.

It is also worth imentioning the development of an unusual precursor, $\left[{ }^{11} \mathrm{C}\right]$ cyanogen bromide. Unlike hydrogen cyanide or any of the other nitriles previously mentioned, cyanogen bromide possesses a reversal of polarity, thus offering the cyano group as an electrophilic reagent. [ $\left.{ }^{11} \mathrm{C}\right]$ Cyanogen bromide is readily prepared in $95 \%$ radiochemical yields from $\mathrm{H}\left[{ }^{11} \mathrm{C}\right] \mathrm{N}$ using a simple solid-phase on-line procedure that involves passing the $\mathrm{H}\left[{ }^{11} \mathrm{C}\right] \mathrm{N}$ through a tube containing pyridinium tribromide and antimony powder. (Westerberg and Långström, 1997)

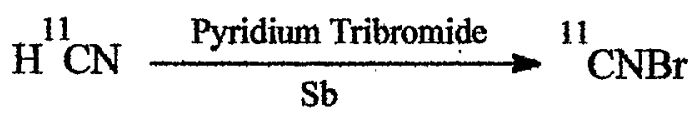

This precursor can allow chemists an opportunity to achieve a variety of useful functional group transformations yielding radiolabelled cyanates, thiocyanates and cyanamides. (Westerberg and Långström, 1993)

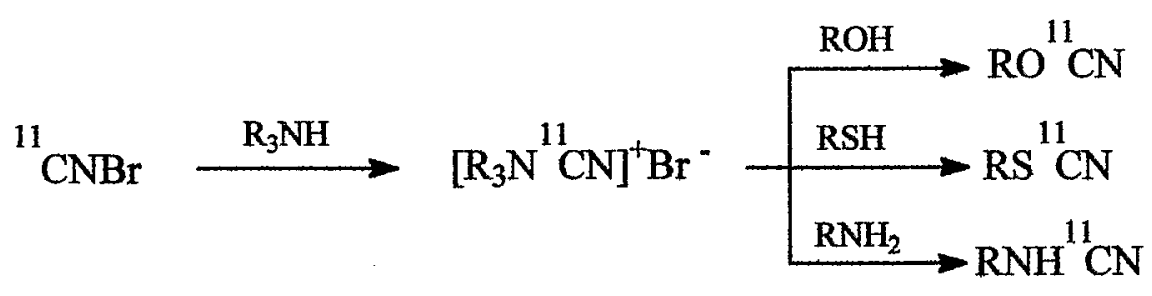

\section{Preparation of $\left[{ }^{11} \mathrm{C}\right]$-Labeled Methylating Agents}

Although some of the earliest syntheses with carbon-11 depended directly on radiolabeled carbon dioxide and cyanide (Fowler and Wolf, 1986) chemists today tend to 
rely on $\left[{ }^{11} \mathrm{C}_{3} \mathrm{H}_{3} \mathrm{I}\right.$ as the precursor of choice for introducing carbon- 11 to organic molecules. (Långström and Lundqvist, 1976; Fowler and Wolf, 1982) This is with good reason as there exists today several commercial systems that will automatically process $\left[{ }^{11} \mathrm{C}_{\mathrm{O}}\right.$ and generate batches of $\left[{ }^{11} \mathrm{C}_{2} \mathrm{H}_{3} \mathrm{I}\right.$ for the chemist.

Carbon-11 labeled methyl iodide can be prepared by both synthetic and nonsynthetic approaches. The most common preparative method depends on the reduction of $\left[{ }^{11} \mathrm{C}^{\mathrm{O}} \mathrm{O}_{2}\right.$ to $\left[{ }^{11} \mathrm{C}_{\mathrm{H}} \mathrm{H}_{3} \mathrm{OH}\right.$ by $\mathrm{LiAlH}_{4}$ followed by subsequent iodination using hydroiodic acid. (Långström and Lundqvist, 1976; Marazano et al., 1977; Iwata et al., 1979)

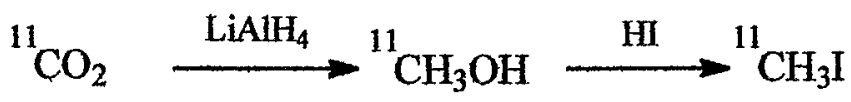

These steps can be easily carried out in a single-pot reactor. However, some precautionary measures should be noted. After the initial trapping of the $\left[{ }^{11} \mathrm{C}^{\mathrm{O}} \mathrm{O}_{2}\right.$ in the $\mathrm{LiAlH}_{4}$, the solvent, which is typically tetrahydrofuran, requires removal using vacuum and heat. Very little loss of carbon-11 is seen during this step, as the activity remains complexed within the lithium salt. However, the salt must be cooled again prior to adding the concentrated hydroiodic acid, or else the exothermicity of the reaction could result in an explosion. Once added, the mixture is again heated to reflux thus allowing the $\left[{ }^{11} \mathrm{C}_{3} \mathrm{H}_{3} \mathrm{I}\right.$ to be distilled off in an inert gas stream. Typically, conversion of $\left[{ }^{11} \mathrm{C}^{\mathrm{O}} \mathrm{O}_{2}\right.$ to ${ }^{11} \mathrm{CH}_{3} \mathrm{I}$ is fast and efficient resulting in greater than $80 \%$ yields of the precursor within 5 to 10 minutes. Of course, the biggest issue is how to maintain some sense of control over the precursor's specific activity. This is especially critical when manipulating $\mathrm{LiAlH}_{4}$ as it will readily absorb carrier $\mathrm{CO}_{2}$ from exposure to air. Special attention must be given to maintaining an inert environment at all times. Typically, precursor specific activities in the range of 1 to $3 \mathrm{Ci} / \mu$ mole are attainable.

Another method that has gained recent popularity relies on a gas-phase synthesis involving $\left[{ }^{11} \mathrm{C}^{1} \mathrm{H}_{4}\right.$ and $\mathrm{I}_{2}$. (Larsen et al. 1997; Link et al., 1997) The process can begin with either $\left[{ }^{11} \mathrm{C}\right] \mathrm{H}_{4}$ that is produced directly within the target, or with $\left[{ }^{1 \mathrm{l}} \mathrm{C}\right] \mathrm{O}_{2}$ which must then be reduced to $\left[{ }^{11} \mathrm{C}^{\mathrm{H}} \mathrm{H}_{4}\right.$ over nickel at $365^{\circ} \mathrm{C}$.

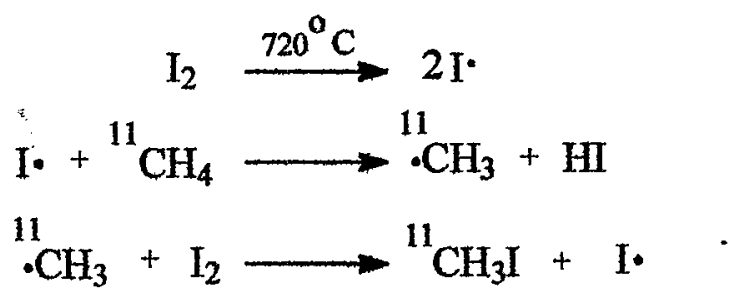

The $\left[{ }^{11} \mathrm{C}_{\mathrm{H}} \mathrm{H}_{4}\right.$ is passed through a quartz tube at $720^{\circ} \mathrm{C}$ which contains $\mathrm{I}_{2}$ vapor. The high temperature dissociates the iodine molecule to generate iodine atoms that are free to abstract hydrogen from an $\left[{ }^{11} \mathrm{C}_{\mathrm{H}} \mathrm{H}_{4}\right.$ molecule. The resulting $\left[{ }^{11} \mathrm{C}\right] \mathrm{H}_{3}$ radical, in turn, attacks another $\mathrm{I}_{2}$ molecule yielding $\left[{ }^{11} \mathrm{C}\right] \mathrm{H}_{3} \mathrm{I}$. The disadvantage of this approach is that the thermolysis induced radical reaction is not terribly efficient, and so, the gas containing the reactants must be recirculated several times through the furnace. Nonetheless, the synthesized $\left[{ }^{11} \mathrm{C}_{3} \mathrm{H}_{3} \mathrm{I}\right.$ can be easily harvested from this recirculated gas stream using porous polymer supports like Porapak $\mathrm{N}$ or Porapak $\mathrm{Q}$, and later released 
for subsequent synthesis. Typically, $40 \%$ of the carbon- 11 is converted to ${ }^{11} \mathrm{C} \mathrm{H}_{3} \mathrm{I}$ with 15 minutes of processing. The yield is more than adequate to produce several hundred millicuries of $\left[{ }^{11} \mathrm{C}\right] \mathrm{H}_{3} \mathrm{I}$ on a per batch basis, with a specific activity of between 6 and 8 $\mathrm{Ci} / \mu$ mole, corrected to end-of-bombardment. Key advantages of this approach are that it is easily automated, and the precursor's specific activity typically exceeds that obtained by the "wet" chemistry method. GE Medical Systems, Inc. (Husbyborg 75229 Uppsala, Sweden) presently markets a fully automated system of this approach.

$\left.{ }^{11} \mathrm{C}\right]$ Methyl iodide can also be prepared by recoil labeling through the proton irradiation of gaseous targets comprised of $\mathrm{N}_{2}$ and $10 \% \mathrm{HI}$. (Wagner et al., 1981) Unfortunately, the precursor yield is only $27 \%$ at low irradiation doses, and is dose sensitive. Attempts to minimize radiolytic destruction of the $\left[{ }^{11} \mathrm{C}\right] \mathrm{H}_{3} \mathrm{I}$ using a high flow of target gas were unsuccessful in making this target practical for producing large amounts of radioactivity. Interestingly enough, this approach does possess potential for producing the highest specific activity of all the methods described. However, the inherent problems associated with manipulating the corrosive target gas, as well as dealing with a low yield of radiolabeled precursor that requires rigorous on-line purification, far outweigh this advantage.

Two other radiolabeled methylating agents are worth mentioning within the scope of this section as they represent attempts to create a more reactive precursor thus allowing chemists to perform methylations under milder conditions. Carbon-11 labeled methyl lithium is one example of this. This precursor can be prepared by an equilibrium reaction between n-butyl lithium and ${ }^{11} \mathrm{C}^{1} \mathrm{H}_{3} \mathrm{I}$. (Reiffers et al., 1979; Reiffers et al., 1980)

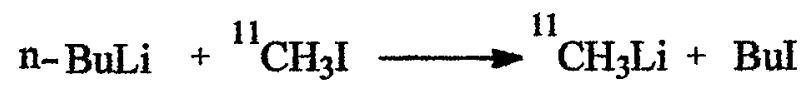

Typically, the interconversion is carried out at low temperature with excess $\mathbf{n}$-butyl lithium to drive the reaction towards the ${ }^{11} \mathrm{C} \mathrm{H}_{3} \mathrm{I}$ side, while at the same time avoiding unwanted coupling. Interconversions are nearly complete within 10 minutes yielding specific activities for the $\left[{ }^{11} \mathrm{C}_{\mathrm{H}} \mathrm{Li}\right.$ that are comparable to that of the starting material, $\left[{ }^{11} \mathrm{C}_{3} \mathrm{H}_{3} \mathrm{I}\right.$. The downside of this process is that a large amount of $\mathrm{n}$-butyl lithium is present which can influence subsequent synthetic steps.

Carbon-11 methyl trifluoromethanesulfonate (methyl triflate) is another example of preparing a more reactive agent that allows chemists an opportunity to carry out alkylations under milder conditions. (Jewett, 1992)

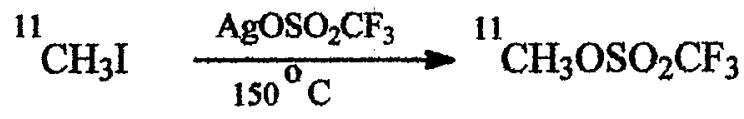

The process for preparing this useful precursor begins by passing $\left[{ }^{11} \mathrm{C}_{3} \mathrm{H}_{3} \mathrm{I}\right.$ through a small soda-glass column containing silver triflate-impregnated graphitized carbon. The conversion to $\left[^{11} \mathrm{C}\right]$ methyl triflate is fast and efficient at $150-200^{\circ} \mathrm{C}$, with the precursor readily trapped at $0^{\circ} \mathrm{C}$ at the outlet stream.

Finally, the $\left[{ }^{11} \mathrm{C}\right]$-labeled Grignard reagent methyl magnesium iodide should be mentioned for its versatility in 1,2-carbonyl additions yielding $\left[{ }^{11} \mathrm{C}\right]-\mathrm{N}$-tert-butyl group on a larger molecule, and in the synthesis of [ $\left.{ }^{11} \mathrm{C}\right]$-sec-alcohols. (Elsinga et al., 1995) 


$$
{ }^{11} \mathrm{CH}_{3} \mathrm{I}+\mathrm{Mg} \frac{\text { diethyl ether, } \mathrm{I}_{2}}{(\mathrm{O}-\mathrm{I}}{ }^{11}{ }^{11} \mathrm{CH}_{3} \mathrm{MgI}
$$

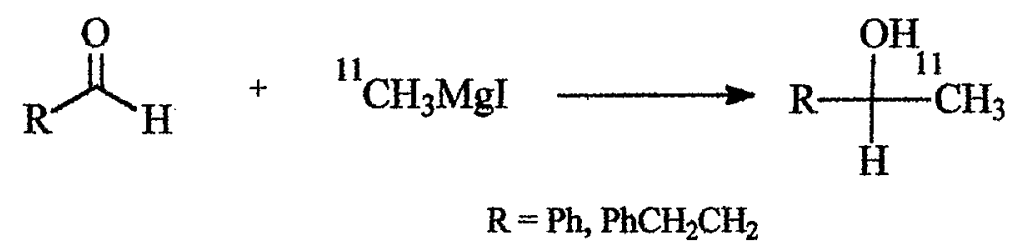

The process involves reaction of $\left[{ }^{11} \mathrm{C} \mathrm{H}_{3} \mathrm{I}\right.$ with magnesium turnings mixed with iodobenzene in ether. The organic halide is an essential component toward initiating the Grignard reaction. Typically, conversions in the range of $60 \%$ to $\left[{ }^{11} \mathrm{C}\right]$ methyl magnesium iodide are obtainable.

\section{E. Preparation of $\left[{ }^{11} \mathrm{C}\right]$ Formaldehyde}

Like many of the other carbon-11 precursors, $\left[{ }^{11} \mathrm{C}\right]$ formaldehyde $\left(\left[{ }^{11} \mathrm{C}\right] \mathrm{H}_{2} \mathrm{O}\right)$ has its utility for allowing chemists to carry out $\left[{ }^{11} \mathrm{C}\right]$-carbonylation reactions. Many procedures have been established to produce $\left[{ }^{11} \mathrm{C} \mathrm{H}_{2} \mathrm{O}\right.$. The methods previously described typically require a two-step process involving reduction of target-produced $\left[{ }^{11} \mathrm{C}^{\mathrm{O}} \mathrm{O}_{2}\right.$ to $\left[{ }^{11} \mathrm{C}_{\mathrm{H}_{3}} \mathrm{OH}\right.$ using lithium aluminum hydride, followed by oxidation of the $\left[{ }^{11} \mathrm{C}_{\mathrm{H}_{3}} \mathrm{OH}\right.$ to $\left[{ }^{11} \mathrm{C}\right] \mathrm{H}_{2} \mathrm{O}$ on metallic converters and catalysts such as silver wool (Marazano et al., 1977) or ferric molybdenum oxide. (Christman et al., 1972; Straatman and Welch, 1975)

$$
{ }^{11} \mathrm{CO}_{2} \stackrel{\mathrm{LiAlH}_{4}}{\longrightarrow}{ }^{11} \mathrm{CH}_{3} \mathrm{OH} \stackrel{\mathrm{Fe}-\mathrm{Mo} \text { Catalyst }}{580^{\circ} \mathrm{C}} \mathrm{H}^{11} \mathrm{CHO}
$$

Two other solution-phase approaches are worth mentioning. The aqueous-phase oxidation of $\left[{ }^{11} \mathrm{C}\right]$ alcohols to $\left[{ }^{11} \mathrm{C}\right]$ aldehydes using tetrabutylammonium bichromate can be successful, but is limited to subsequent chemistry tolerant of the aqueous environment. (Halldin and Långström, 1984) Another recent approach relies on the direct reduction of $\left[{ }^{11} \mathrm{C}\right] \mathrm{O}_{2}$ to $\left[{ }^{11} \mathrm{C}\right] \mathrm{H}_{2} \mathrm{O}$ using metal hydrides at low temperature. (Nader et al., 1997) Typically, $58 \%$ yields of $\left[{ }^{11} \mathrm{C}^{1} \mathrm{H}_{2} \mathrm{O}\right.$ can be attained using lithium aluminum hydride in tetrahydrofuran at $-50^{\circ} \mathrm{C}$. The nature of the metal hydride, as well as the solvent temperature are key to optimizing the reduction. For instance the radiochemical purity of the precursor drops significantly above $-45^{\circ} \mathrm{C}$ due to large yields of $\left[{ }^{11} \mathrm{C}^{-} \mathrm{H}_{3} \mathrm{OH}\right.$ produced in the process.

\section{F. Preparation of $\left[{ }^{11} \mathrm{C}\right]$ Phosgene}

As an acid chloride, $\left[{ }^{11} \mathrm{C}\right]$ phosgene $\left(\left[{ }^{11} \mathrm{C}\right] \mathrm{OCl}_{2}\right)$ opens up many possibilities for preparation of other useful precursors. The preparation of anhydrous $\left[{ }^{11} \mathrm{C}\right]$ urea from ${ }^{11} \mathrm{C}^{1} \mathrm{OCl}_{2}$ is one such example where the [11C]urea precursor can be subsequently used to synthesize $2-\left[{ }^{11} \mathrm{C}\right]$ thymidine. (Steel' et al., 1993; Steel et al., 1999) Other possibilities include the synthesis of $\left[{ }^{11} \mathrm{C}\right]$ alkyl carbonates from reaction of ${ }^{11} \mathrm{COCl}_{2}$ with alcohol, or 
the synthesis of $\left[{ }^{11} \mathrm{C}\right]$ alkyl carbamates from combined reaction with alcohol and ammonia.

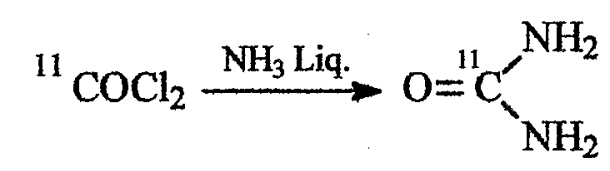

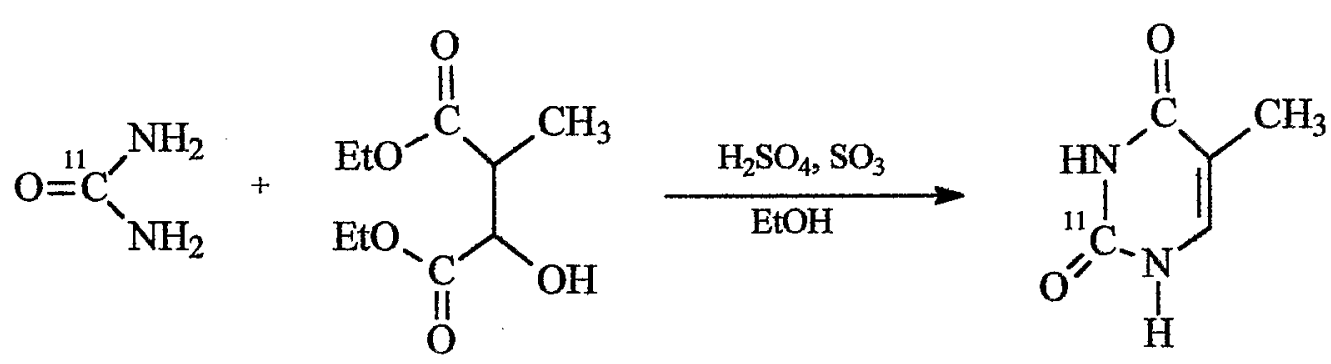

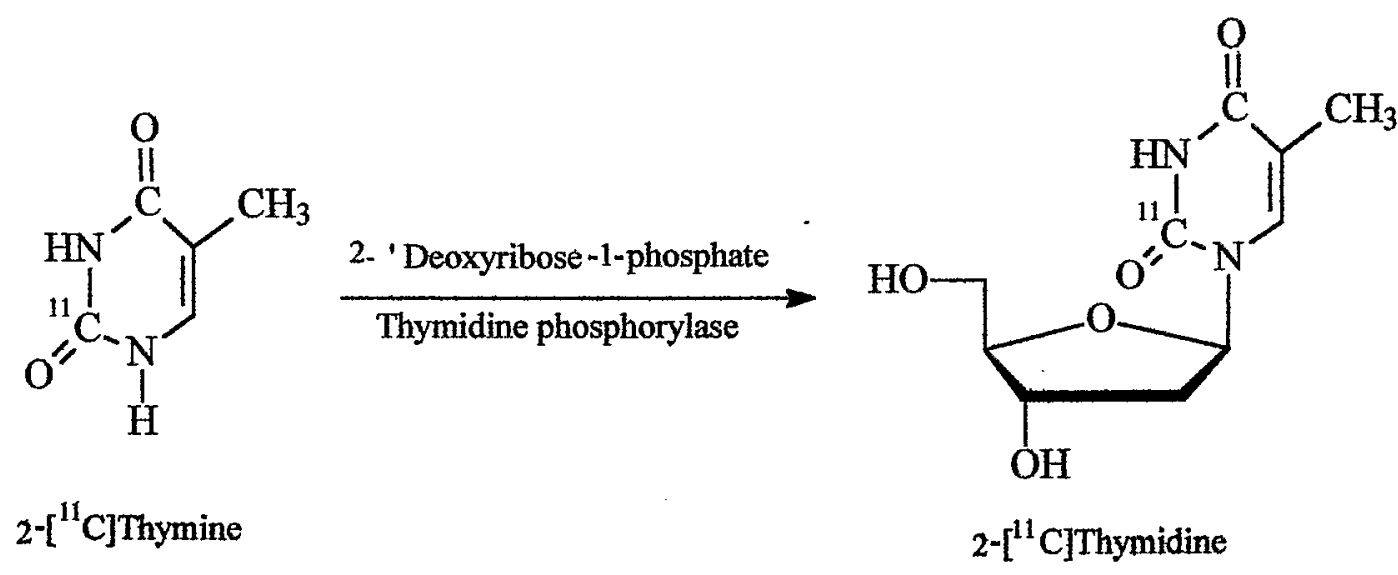

Perhaps one of the oldest methods for preparing $\left[{ }^{11} \mathrm{C}_{\mathrm{OCCl}}\right.$ involves the ultraviolet photochemical reaction between $\left[{ }^{11} \mathrm{C}\right] \mathrm{O}$ and $\mathrm{Cl}_{2}$. (Brinkman et al., 1978; Christman et al., 1979; Roeda and Westera, 1981) The conversion is fast and quantitative when conducted under static conditions using excess $\mathrm{Cl}_{2}$ gas.

$$
{ }^{11} \mathrm{CH}_{4}+\mathrm{Cl}_{2} \stackrel{\mathrm{h} \gamma}{\longrightarrow}{ }^{11} \mathrm{COCl}_{2}
$$

In addition, the $\left[{ }^{11} \mathrm{C}\right] \mathrm{OCl}_{2}$ is readily purified by passing the ampoule contents over antimony metal to remove the excess $\mathrm{Cl}_{2}$.

Another method that relies on $\left[{ }^{11} \mathrm{C}\right] \mathrm{O}$ involves a catalytic chlorination reaction. (Roeda et al. 1978) Typically, $\left[{ }^{11} \mathrm{C}\right] \mathrm{O}$ is produced through reduction of $\left[{ }^{11} \mathrm{C}\right] \mathrm{O}_{2}$ over hot zinc, as described earlier in this chapter. The gas effluent from this step is simply passed through a second furnace at $280^{\circ} \mathrm{C}$ containing $\mathrm{PtCl}_{4}$.

$$
{ }^{11} \mathrm{CO}_{2} \underset{450^{\circ} \mathrm{C}}{\text { zinc asbestos }}{ }^{11} \mathrm{CO} \stackrel{\mathrm{PtCl}_{4}}{280^{\circ} \mathrm{C}}{ }^{11} \mathrm{COCl}_{2}
$$


The conversion of $\left[{ }^{11} \mathrm{C}\right] \mathrm{O}-$ to- $\left[{ }^{11} \mathrm{C}_{\mathrm{OOCl}}\right.$ is usually $60 \%$, and while less than the photochemical reaction, does offer the advantage of a flow system for manipulating the radioactive substances.

One other approach is worth mentioning because of its ability to produce large amounts of $\left[{ }^{11} \mathrm{C}_{\mathrm{OCCl}}\right.$ relatively quickly. This method involves a two-step process. First, $\left[{ }^{11} \mathrm{C}_{\mathrm{H}} \mathrm{H}_{4}\right.$ is converted to $\left.{ }_{[}^{11} \mathrm{C}\right] \mathrm{Cl}_{4}$ through reaction with $\mathrm{Cl}_{2}$ gas at $390^{\circ} \mathrm{C}$. The conversion under flow conditions is typically fast and in under 10 minutes, providing a $70 \%$ yield of $\left[{ }^{11} \mathrm{C}_{\mathrm{Cl}}\right.$. The source of $\left[{ }^{11} \mathrm{C}\right] \mathrm{H}_{4}$ can either be from the $\mathrm{N}_{2}+\mathrm{H}_{2}$ gas target where $\mathrm{Cl}_{2}$ gas is mixed with the target gas during unloading. Another way is to start with $\left[{ }^{11} \mathrm{C}^{\mathrm{O}} \mathrm{O}_{2}\right.$ produced from the $\mathrm{N}_{2}+\mathrm{O}_{2}$ target. The advantage here is that the $\left[{ }^{11} \mathrm{C}\right] \mathrm{O}_{2}$ can be easily trapped during target unloading on molecular sieve/reduced nickel at ambient temperature, reduced to $\left[{ }^{11} \mathrm{C}_{\mathrm{H}} \mathrm{H}_{4}\right.$ and then slowly flowed through the chlorination furnace. Either source of carbon-11 will suffice. The $\left[{ }^{11} \mathrm{C}_{C} \mathrm{Cl}_{4}\right.$ produced in the chlorination step is then mixed in a stream of $\mathrm{O}_{2}$ gas, and passed through a second furnace at $300^{\circ} \mathrm{C}$ containing iron granules. (Steel et al., 1999)

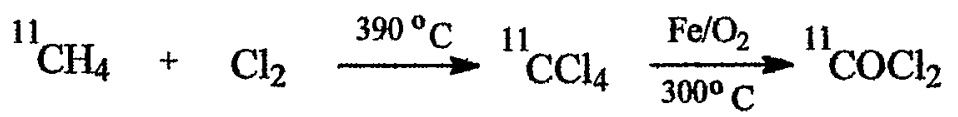

The conversion of ${ }^{11} \mathrm{CCl}_{4}$ to ${ }^{11} \mathrm{COCl}_{2}$ is about $79 \%$ and takes only about 3 minutes to complete. The ${ }^{11} \mathrm{COCl}_{2}$ can be easily purified online by passing the gas effluent through metallic antimony.

\section{G. Preparation of $\mathbf{C}_{2}$ and Larger $\left[{ }^{11} \mathbf{C}\right]$ Alkyl Iodides}

Carbon-11 labeled alkyl iodides such as ethyl, propyl, and butyl iodides are useful precursors that enable the chemist the ability to extend the size of the side alkyl chain beyond that of a simple methyl group. (Långström et al., 1986) This is sometimes desirable when designing the radiotracer with the radioactive label on different positions of the molecule. One application of this is the radiolabeling of $\mathrm{N}, \mathrm{N}$-dipropyl-2-[4methoxy-3-(2-phenylethoxy)phenyl]ethylamine (NE-100) in two different positions by alkylating the $\mathrm{N}$-despropyl precursor with $\left[{ }^{1 \mathrm{l}} \mathrm{C}\right]$ propyl iodide, and the O-desmethyl precursor with $\left[{ }^{11} \mathrm{C}\right]$ methyl iodide. (Ishiwata et al., 1998) Another reason for adding these alkyl iodides to the arsenal of labeling precursors is that they provide a useful springboard for generating precursors with other functionalities.

The standard approach for preparing $\left[{ }^{11} \mathrm{C}\right]$ alkyl iodides consists of the reaction of a Grignard reagent with $\left[{ }^{11} \mathrm{C}^{\mathrm{O}} \mathrm{O}_{2}\right.$ followed by reduction using lithium aluminum hydride and finally reaction with aqueous hydroiodic acid. A drawback to this approach is that it will produce $\left[{ }^{11} \mathrm{C}_{3} \mathrm{H}_{3} \mathrm{I}\right.$ as a by-product. Unfortunately, $\left[{ }^{11} \mathrm{C}\right] \mathrm{H}_{3} \mathrm{I}$ is more reactive than any of the higher-order akyl iodides, and thus poses problems by potentially hindering the radiolabeling effectiveness of the desired alkyl iodide precursor, as well as in producing unwanted radiolabeled by-products that necessitate more complex purification schemes. The former issue is especially noteworthy in view of the fact that larger amounts of carrier $\mathrm{CH}_{3} \mathrm{I}$ mass are produced in the process owing to $\mathrm{CO}_{2}$ contamination of the lithium aluminum hydride. Chemists typically address these issues by designing an additional purification step into the synthetic scheme prior to reaction with the labeling substrate. One approach that has been extremely successful, owing to the volatility of the alkyl iodide precursors, is the use of gas chromatography. While this may sound complicated 
in the normal scheme of things, it can be a rather simply solution to the problem and amenable to automation. (Ishiwata et al., 1999) Radiochemical yields after gas chromatography were on the order of $27 \%, 22 \%$ and $12 \%$ for $\left[{ }^{11} \mathrm{C}\right]$ ethyl iodide, $\left[{ }^{11} \mathrm{C}\right]$ propyl iodide and $\left[{ }^{11} \mathrm{C}\right]$ butyl iodide, respectively, with preparation times increasing proportionally with the size of the alkylating agent from 12 to 19 minutes.

\section{H. Preparation of $\left[{ }^{11} \mathrm{C}\right]$ Nitroalkanes}

The development of $\left[{ }^{11} \mathrm{C}\right]$-labeled nitroalkanes as a class of synthetic precursors occurred out of necessity to increase flexibility in radiochemistry. (Schoeps et al., 1989; Schoeps et al., 1991) Nitroalkanes are a versatile class of labeling precursor in the sense that they can be readily converted into carbon nucleophiles by the addition of base. Their reactions through nucleophilic substitution and aldehyde condensation are well documented. (Mathieu and Weill-Raynal, 1973) Once reacted, the nitro group can be easily converted to other functionalities such as a carbonyl group (Nef's reaction) or reduced to an amine.

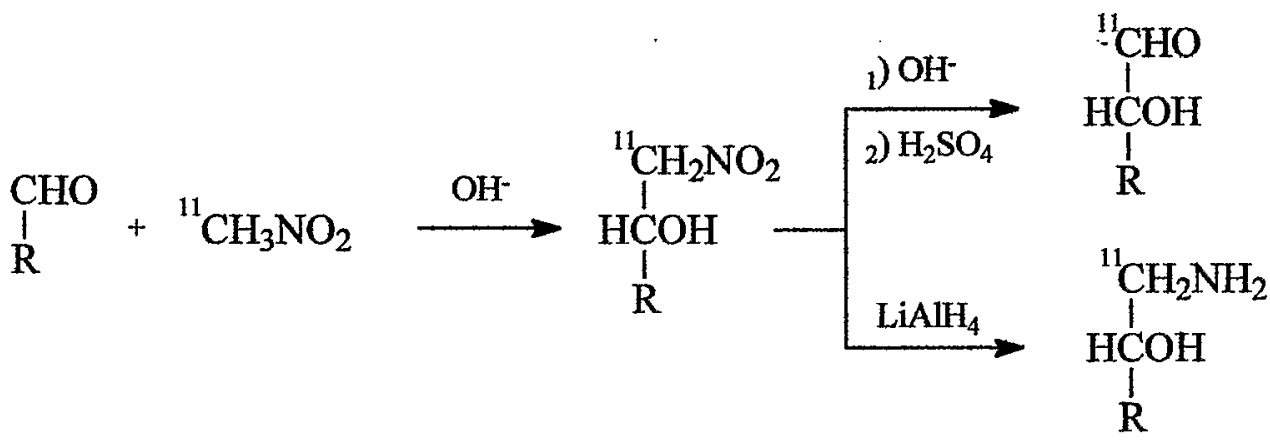

The synthetic importance of this class of labeling precursor has been demonstrated using $\left[{ }^{11} \mathrm{C}\right]$ nitromethane in the synthesis of $\left[{ }^{11} \mathrm{C}\right]$ phenethylamine (Schoeps and Halldin, 1992) and $\left[{ }^{11} \mathrm{C}\right]$ dopamine (Schoeps et al., 1993) via condensation with the appropriate aldehydes to yield the corresponding $\left[{ }^{11} \mathrm{C}\right]$ nitrostyrenes.

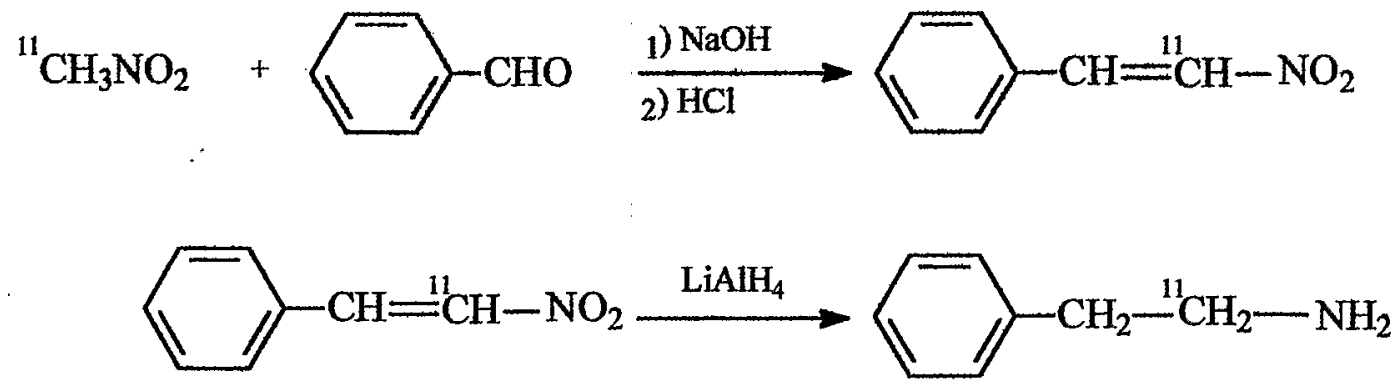

More recently, the utility of this class of precursor was extended by developing a strategy where the $\left[{ }^{11} \mathrm{C}\right] \beta$-nitrophenethyl alcohols could be obtained in preference to the 
styrene product through condensation of $\left[{ }^{11} \mathrm{C}\right]$ nitromethane with various substituted benzaldehydes using tetrabutylammonium fluoride (TBAF) as a catalyst. This strategy can then allow for the preparation of $\left[{ }^{11} \mathrm{C}\right]$-labeled phenylethanolamines such as norphenylephrine and norepinephrine. (Nagren et al., 1994)

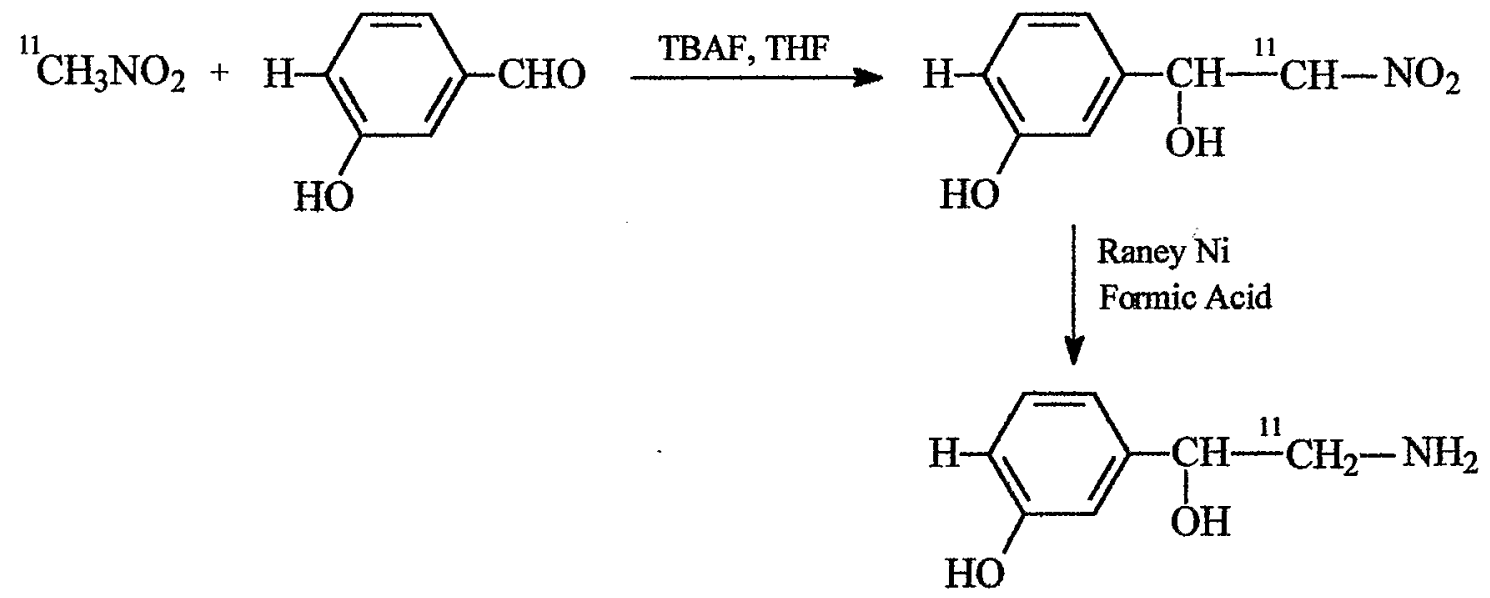

Nitroalkanes labeled with carbon-11 can be easily prepared by reacting the appropriate $\left[{ }^{11} \mathrm{C}\right]$ alkyl iodide with silver nitrite at $80^{\circ} \mathrm{C}$.

$$
\begin{gathered}
\mathrm{R}-{ }^{\prime \prime} \mathrm{CH}_{2} \mathrm{I} \quad \frac{\mathrm{AgNO}_{2}}{80^{\circ} \mathrm{C}} \mathrm{R} \stackrel{-1}{-} \mathrm{CH}_{2} \mathrm{NO}_{2} \\
\mathrm{R}=\mathrm{H}, \mathrm{CH}_{3}, \mathrm{C}_{2} \mathrm{H}_{5}
\end{gathered}
$$

This approach is amenable to on-line processing where the purified $\left[{ }^{11} \mathrm{C}\right]$ alkyl iodide is flowed in a nitrogen or helium stream through a $3 \mathrm{~mm}$ id $\times 4 \mathrm{~cm}$ length soda glass column packed with $0.4 \mathrm{~g}$ of silver nitrite at $20-30 \mathrm{~mL} / \mathrm{min}$. (Schoeps et al., 1989) Radiochemical yields (based on ${ }^{11} \mathrm{CO}_{2}$ ) of $55 \%, 30 \%$ and $40 \%$ are typical for preparing $\left[{ }^{11} \mathrm{C}\right]$ nitromethane, $\left[{ }^{11} \mathrm{C}\right]$ nitroethane and $\left[{ }^{11} \mathrm{C}\right]$ nitropropane, respectively.

\section{Preparation of $\left[{ }^{11} \mathbf{C}\right]$ Alkylthiols}

In yet another class of precursor that includes the $\left[{ }^{11} \mathrm{C}\right]$ alkylthiols, the chemist has the ability to carry out S-alkylation reactions. One area where these precursors have been useful is in the enzymatic synthesis of 2-amino-4-([ $\left[{ }^{11} \mathrm{C}\right]$ methylthio)butyric acid $\left({ }^{11} \mathrm{C}\right]$ methionine) and its derivatives using immobilized $\gamma$-cyano- $\alpha$-aminobutyric acid synthase. [ $\left.{ }^{11} \mathrm{C}\right]$ Methionine is widely used for clinical PET studies on amino acid metabolism in tumors (Strauss and Conti, 1991; Koh et al., 1994; Leskinen et al., 1997) as well as in the brain. (Bustany, 1983; O'Tauma et al., 1991; Salmon et al., 1996)

Synthetically, the $\left[{ }^{11} \mathrm{C}\right]$ alkylthiols derive from a pure source of $\left[{ }^{11} \mathrm{C}\right]$ alkyl iodides. (Suehiro et al., 1995; Kaneko et al., 1999) A number of synthetic methodolgogies have been tested including the use of heated reaction tubes. By far, the best procedure involves trapping the purified alkyl iodides in a $0.2 \mathrm{~mL}$ solution of DMF containing $2 \mathrm{mg}$ of NaSH. The contents are then heated to $120^{\circ} \mathrm{C}$, and the $\left[{ }^{11} \mathrm{C}\right]$ alkylthiols are 
immediately transferred under a nitrogen or helium gas stream to a second vessel where they can react. Typically, this approach will produce radiochemical yields of $91 \%, 92 \%$ and $98 \%$ for $\left[{ }^{11} \mathrm{C}\right]$ methanethiol, $\left[{ }^{11} \mathrm{C}\right]$ ethanethiol and $\left[{ }^{11} \mathrm{C}\right]$ propanethiol, respectively. Interestingly enough, reaction efficiencies are extremely sensitive to the level of $\mathrm{O}_{2}$ dissolved in the DMF solvent. Yields decrease when too little or too much $\mathrm{O}_{2}$ is present. The exact reason for this behavior is not clear. However, peak performance for preparing these precursors appears to occur when the NaSH is dissolved in the DMF at room temperature approximately 30 to 40 minutes prior to use.

\section{J. Preparation of $\left[{ }^{11} \mathrm{C}\right]$ Urea}

Over the years, $\left[{ }^{11} \mathrm{C}\right]$ urea has received considerable attention owing to its use in synthesizing $2-\left[{ }^{11} \mathrm{C}\right]$-thymidine, a radiotracer that has been investigated for in vivo monitoring of cell proliferation in tumors using PET. (Van der Borght et al., 1991; Labar and Van der Borght, 1991) The development of a tracer to monitor DNA synthesis has far reaching applications for the investigation of both tumor growth and response to antiproliferation therapies, although the use of $2-\left[{ }^{11} \mathrm{C}\right]$-thymidine is limited by the presence of labeled metabolites. (Van der Borght et al., 1990; Shields et al., 1990; Shields, 1993)

Two methodologies for preparing usable quantities of $\left[{ }^{11} \mathrm{C}\right]$ urea are available. These approaches are depicted below.

$$
\begin{aligned}
& { }^{11} \mathrm{CH}_{4}+\mathrm{NH}_{3} \frac{\mathrm{Pt}}{1000^{\circ} \mathrm{C}} \mathrm{H}^{11} \mathrm{CN} \frac{\mathrm{KMnO}_{4}}{\text { aq. } \mathrm{KOH}} \mathrm{KO}^{11} \mathrm{CN} \frac{\left(\mathrm{NH}_{3}\right)_{2} \mathrm{SO}_{4}}{\mathrm{EtOH}} \\
& { }^{11} \mathrm{CH}_{4}+\mathrm{Cl}_{2} \stackrel{390^{\circ} \mathrm{C}}{\longrightarrow}{ }^{11} \mathrm{CCl}_{4} \frac{\mathrm{Fe} / \mathrm{O}_{2}}{{ }_{300^{\circ} \mathrm{C}}}{ }^{11} \mathrm{COCl}_{2} \stackrel{\mathrm{NH}_{3} \text { Liq. }}{\longrightarrow} \longrightarrow \mathrm{O}^{11} \mathrm{C}^{\prime} \mathrm{NH}_{2}
\end{aligned}
$$

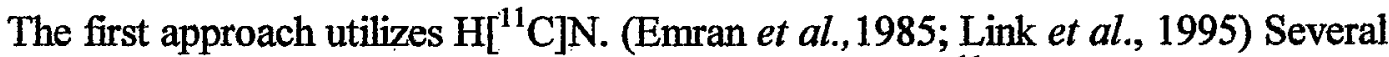
schemes have already been discussed for the preparation of $\left.\mathrm{H}^{11} \mathrm{C}\right] \mathrm{N}$. The formation of urea from this precursor begins by converting it to $\left[{ }^{11} \mathrm{C}_{N} \mathrm{NH}_{4} \mathrm{CN}\right.$. This is accomplished by collecting the $\mathrm{H}\left[{ }^{11} \mathrm{C}\right] \mathrm{N}$ in $0.2 \mathrm{~mL}$ of $\mathrm{KMnO}_{4}(0.032 \mathrm{M})$ containing $0.05 \mathrm{~mL} \mathrm{KOH} \mathrm{(2M).}$ The ${ }^{11} \mathrm{CN} / \mathrm{MnO}_{4}^{-}$mixture is heated to $100^{\circ} \mathrm{C}$ after which $0.2 \mathrm{~mL}\left(\mathrm{NH}_{4}\right) \mathrm{SO}_{4}(0.75 \mathrm{M})$ and $0.1 \mathrm{~mL}$ ethanol are added. The mixture is again heated to $170^{\circ} \mathrm{C}$ for 3 minutes. Separation of insoluble $\mathrm{MnO}_{2}$ from the reaction mixture is accomplished by filtering through a disposable column possessing a $0.45 \mu \mathrm{m}$ filter. The alcoholic urea mixture must then be dried prior to further reaction. Radiochemical yields are typically greater than $35 \%$.

A second approach to preparing anhydrous $\left[{ }^{11} \mathrm{C}\right]$ urea utilizes $\left[{ }^{11} \mathrm{C}\right]$ phosgene. (Steel et al., 1993) Like $\mathrm{H}\left[{ }^{11} \mathrm{C}\right] \mathrm{N}$, there are several methods to preparing the starting precursor, $\left[{ }^{11} \mathrm{C}\right]$ phosgene, all of which have been discussed earlier. The $\left[{ }^{11} \mathrm{C}\right]$ phosgene, as it is produced on-line, is mixed with a stream of oxygen at $10 \mathrm{~mL} / \mathrm{min}$ and passed through a vessel containing $300 \mu \mathrm{L}$ of liquid ammonia maintained at $-33^{\circ} \mathrm{C}$. After about 5 minutes, the vessel is warmed to remove the ammonia thus allowing the $\left[{ }^{11} \mathrm{C}\right]$ urea to be taken up in a suitable anhydrous solvent. Total radiochemical yield by this approach is 
about $30 \%$. This approach does offer a slight advantage in that it appears easier to automate. (Steel et al, 1999)

\section{K. Preparation of $\left[{ }^{11} \mathrm{C}\right]$ Acetone}

Carbon-11 labeled acetone is a useful precursor in the synthesis of radiolabeled compounds containing isopropyl (Berridge et al., 1992; Rubottom and Kim, 1983) or acetonide functions. (Berridge et al., 1994) Most recently, $\left[{ }^{11} \mathrm{C}\right]$ procaterol, a $\beta_{2^{-}}$ adrenoceptor agonist, has been radiolabeled for PET using this precuror. (Visser et al., 2000)

The general approach to preparing $\left[{ }^{11} \mathrm{C}\right]$ acetone is through reaction of $\left[{ }^{11} \mathrm{C}\right] \mathrm{O}_{2}$ with methyl lithium. (Berger et al., 1980) Typically, the organolithium reagent is present in large excess relative to the no-carrier-added concentrations of $\left[{ }^{11} \mathrm{C}\right] \mathrm{O}_{2}$. This aspect has a downside in that large amounts of $\left[{ }^{11} \mathrm{C}\right]$ tert-butanol are also produced at the expense of $\left[{ }^{11} \mathrm{C}\right]$ acetone.

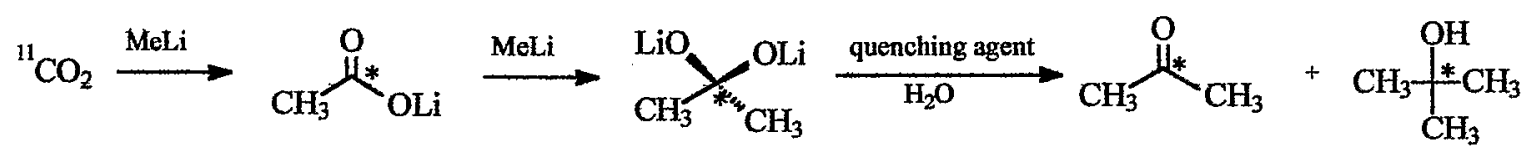

However, a slight modification to this methodology includes introducing diphenylamine to selectively quench the excess organolithium reagent prior to hydrolysis of the acetone diolate intermediate. (Studenov et al., 1999) This modification allows for $100 \%$ radiochemical yields of $\left[{ }^{11} \mathrm{C}\right]$ acetone to be produced.

\section{Preparation of $\left[{ }^{11} \mathrm{C}\right]$-Labeled Phosphonium Salts used as Wittig Reagents}

The Wittig reaction is typically used for extending carbon chains with one or more carbon atoms by converting aldehydes and ketones into alkenes. (Maryanoff and Reitz, 1989) This reaction has been applied to the carbon-11 radiolabelling of several terminal and branch-chained alkenes (Kihlberg et al., 1990; Grierson et al., 1993), and more recently improved upon by utilizing polymer-bound reagents.(Ogren et al., 1995)<smiles>[R]c1ccc(C=C)cc1</smiles> 
In typical reactions, $\left[{ }^{11} \mathrm{C}_{3} \mathrm{H}_{3} \mathrm{I}\right.$ is trapped at ambient temperature in a solvent solution of $10 \%$ tetrahydrofuran and $o$-dichlorobenzene containing $3 \mu \mathrm{mol}$ of the polymer-bound triphenylphosphine. Polystyrene cross-linked with $2 \%$ divinylbenzene works well as the polymer support. After trapping, the mixture is heated to $160^{\circ} \mathrm{C}$ for 3 minutes to allow the radiolabeled phosphonium salt to form. Once cooled, $0.20 \mathrm{mmol}$ of the appropriate aldehyde in $o$-dichlorobenzene solvent is added and the reaction is again heated for 3 minutes at $160^{\circ} \mathrm{C}$. Radiochemical yields ranging from $29-65 \%$ are typical depending on the nature of the aldehyde substrate.

\section{Precursors Labeled with Fluorine-18}

\section{A. Nuclear Reactions for Producing Fluorine-18}

Unlike carbon-11, fluorine-18 possesses a much lower positron energy (a maximum range of $2.4 \mathrm{~mm}$ ) thus making it a very attractive radioisotope for localization measurements requiring high-resolution PET. An additional advantage is that it possesses a significantly longer half-life $(110 \mathrm{~min})$ than carbon-11 thus affording the radiochemist additional time to perform more complex synthetic manipulations. Over the years a number of nuclear reactions have been explored for their efficacy in generating synthetically useful quantities of fluorine-18. Table 3 lists these reactions along with pertinent nuclear data.

In the early days, fluorine-18 was a reactor produced radioisotope requiring a rather complicated two-step process involving fast neutron bombardment of a solid lithium- 6 target to generate the requisite tritons to drive the ${ }^{16} \mathrm{O}(\mathrm{t}, \mathrm{n})^{18} \mathrm{~F}$ reaction. Issues regarding tritium contamination within the beam-line as well as within the target never made this a practical approach. Today, cyclotron production is clearly the method of choice owing to the greater simplicity of the target designs, as well as the over-all higher yields of the radioisotope. The most commonly used nuclear reactions to produce fluorine-18 include the ${ }^{18} \mathrm{O}(\mathrm{p}, \mathrm{n}){ }^{18} \mathrm{~F}$ and ${ }^{20} \mathrm{Ne}(\mathrm{d}, \alpha){ }^{18} \mathrm{~F}$ reactions with the proton bombardment on enriched oxygen-18 providing significantly higher yields and improved precursor specific activity. (Ruth and Wolf, 1979) One's decision in selecting a particular method over another for production is contingent on several factors including: (i) whether the available cyclotron is capable of multiple particles; (ii) whether it is desirable for the fluorine-18 source to be aqueous or anhydrous; (iii) whether the radiolabeled precursor needs to be nucleophilic or electrophilic; and (iv) whether that precursor needs to possess a high specific activity. As a general rule to follow, proton irradiation of enriched water will yield an aqueous source of $\left[{ }^{18} \mathrm{~F}\right]$ fluoride for nucleophilic displacements while deuteron irradiation of neon will yield an anhydrous source of electrophilic fluorine-18 typically as elemental fluorine. However, as one reads on it will become apparent that many of these selection criteria are not as critical today as they were in the past. Now it is possible to render an aqueous source of $\left[{ }^{18} \mathrm{~F}\right]$ fluoride anhydrous as well as interconvert the nucleophilic fluoride into electrophilic reagents. 


\section{B. Electrophilic Fluorination Reagents Labeled with Fluorine-18}

Electrophilic reagents create a chemical environment in which the fluorine atom is highly polarized with a positive charge. In this way, it is possible to fluorinate a variety of electron-rich substrates including alkenes, aromatic compounds and carbanions with fluorine-18. Over the years several reviews on the subject of electrophilic fluorination have been written. The reader is encouraged to seek out these works for greater detail on the subject.(Kilbourn, 1990; Rozen, 1988; Wilkinson, 1992; Berridge, 1986) Without a doubt, electrophilic fluorination reactions are fast and efficient making them highly desirable synthetic pathways to achieve radiopharmaceuticals labeled with fluorine-18. The only downside seen is that most fluorine-18 labeled electrophilic reagents derive from $\left[{ }^{18} \mathrm{~F}\right] \mathrm{F}_{2}$ which suffers from low specific activity.

\section{i. Preparation of Fluorine-18 Labeled Elemental Fluorine:}

The simplest reagent in this class of precursors is $\left[{ }^{18} \mathrm{~F}\right] \mathrm{F}_{2}$. It typically is produced through the deuteron bombardment of a high-pressure neon gas target containing 0.1 to $2 \%$ of carrier $\mathrm{F}_{2}$. (Casella et al., 1980) The method, however, suffers in specific activity due to the carrier addition with practical limits around $12 \mathrm{Ci} / \mathrm{mmole}$. (Blessing $e t$ al., 1986) Two variations on this approach involve proton irradiations of ${ }^{18} \mathrm{O}$-enriched $\mathrm{O}_{2}$ gas targets. Both methods rely on the fact that fluorine-18 will remain trapped on the target walls when there is no carrier present during the irradiation to chemically scrub the isotope. In the first approach, a mixture comprised of hydrogen and helium gases is swept through the target after bombardment while the target is heated to $600^{\circ} \mathrm{C}$. The fluorine-18 is recovered as $\mathrm{H}\left[{ }^{18} \mathrm{~F}\right]$, and later converted to $\left[{ }^{18} \mathrm{~F}\right] \mathrm{F}_{2}$ through microwave discharge using a mixture of $5 \%$ carrier $\mathrm{F}_{2}$ in helium. (Straatman et al., 1982) The rigors of heating a target to such high temperature eventually take their toll on pressure seals and internal surfaces.

A second more practical variation on this concept involves the same target irradiations as described in the first with the exception that a small amount of carrier $F_{2}$ is added to the target, and it is briefly re-irradiated. This manipulation allows for relatively efficient exchange of the fluorine +18 producing a source of $\left[{ }^{8} \mathrm{~F}^{\mathrm{F}} \mathrm{F}_{2}\right.$. (Nickels et al., 1984; Solin and Bergman, 1986)

A more recent approach for generating higher specific activity $\left[{ }^{18} \mathrm{~F}_{\mathrm{F}} \mathrm{F}_{2}(1.5\right.$ $\mathrm{Ci} / \mu \mathrm{mol})$ involves a two-step process beginning with $\left[{ }^{18} \mathrm{~F}\right]$ fluoride produced from the ${ }^{18} \mathrm{O}(\mathrm{p}, \mathrm{n}){ }^{18} \mathrm{~F}$ reaction on ${ }^{18} \mathrm{O}$-enriched water. (Bergman, 1997) The aqueous fluoride solution, as $\mathrm{K}^{18} \mathrm{~F}$, is mixed with kryptofix and acetonitrile followed by heating to dryness. A small amount of methyl iodide in acetonitrile solvent is then added to the dry residue to yield $\mathrm{CH}_{3}\left[{ }^{18} \mathrm{~F}\right]$ within 1 minute. The $\mathrm{CH}_{3}\left[{ }^{18} \mathrm{~F}\right]$ is flushed with neon gas into a quartz discharge chamber containing 150 nmole of carrier $F_{2}$ where the mixture is discharged at $20-30 \mathrm{keV}, 280 \mu \mathrm{A}$, for 10 seconds resulting in about $30 \%$ conversion of the original $\left[{ }^{18} \mathrm{~F}\right]$ fluoride to $\left[{ }^{18} \mathrm{~F}\right] \mathrm{F}_{2}$.

\section{ii. Preparation of Fluorine-18 Labeled Trifluoromethyl Hypofluorite:}

Over the years, several other electrophilic $\left[{ }^{18} \mathrm{~F}\right]$ fluorinating agents have been successfully prepared and applied in the laboratory. $\left[{ }^{18} \mathrm{~F}\right]$ Trifluoromethyl hypofluorite, $\mathrm{CF}_{3} \mathrm{O}\left[{ }^{18} \mathrm{~F}\right]$, was the first in a line of a subclass of "milder" electrophilic fluorinating agents that offered more regioselective control with less degradation to substrate. (Neirinckx et al., 1978) The process of production involves cesium fluoride mediated 
reaction between $F_{2}$ and carbonyl fluoride. The reaction is conducted within an $F_{2}-$ passivated nickel irradiation target. Without carrier present, the target walls will retain all of the fluorine-18 radioactivity upon removal of the irradiation gas. The target is then used as a reaction vessel into which cesium, fluoride, $F_{2}$ and carbonyl fluoride are introduced. Optimal results are obtained within 15 minutes of reaction at $110^{\circ} \mathrm{C}$ producing a $33 \%$ yield of $\mathrm{CF}_{3} \mathrm{O}\left[{ }^{18} \mathrm{~F}\right]$.

\section{iii. Preparation of Fluorine-18 Labeled Acetyl Hypofluorite:}

The preparation of this important precursor has been re-examined over the years for a couple of reasons. Compared to $\left[{ }^{18} \mathrm{~F}^{\mathrm{F}} \mathrm{F}_{2}\right.$, it is milder as a fluorinating agent. Perhaps more importantly, it possesses a much greater solubility over a wider range of reaction solvents. In the original methodology, $\left[{ }^{18} \mathrm{~F}\right] \mathrm{F}_{2}$ produced from a neon gas target is slowly emptied into a glass reaction vessel containing a solution of aqueous ammonium hydroxide in glacial acetic acid. (Shiue et al., 1982)

$$
\left[{ }^{18} \mathrm{~F}_{2} \mathrm{~F}_{2}+\mathrm{CH}_{3} \mathrm{CO}_{2} \mathrm{NH}_{4} \stackrel{\text { Acetic Acid }}{\longrightarrow} \mathrm{CH}_{3} \mathrm{CO}_{2}{ }^{18} \mathrm{~F}+\mathrm{NH}_{4}{ }^{18} \mathrm{~F}\right.
$$

Reaction is almost immediate yielding $40 \% \mathrm{CH}_{3} \mathrm{CO}_{2}\left[{ }^{18} \mathrm{~F}\right]$ although the process of emptying the pressurized target in a controlled manner is a limiting factor. Most likely, any method for generating $\left[{ }^{18} \mathrm{~F}\right] \mathrm{F}_{2}$ will suffice for this reaction although deuteron irradiation on neon $/ F_{2}$ mixtures would seem the course to take. Preparation of this precursor was greatly simplified and made more reliable by the development of a gassolid phase reaction. (Jewett et al., 1984; Chirakal et al., 1988)

$$
\left[{ }^{18} \mathrm{~F}_{2}+\mathrm{AcOH} \cdot \mathrm{AcOK} \longrightarrow \mathrm{CH}_{3} \mathrm{CO}_{2}{ }^{18} \mathrm{~F}+\left[{ }^{18} \mathrm{~F}\right] \mathrm{HF} \cdot \mathrm{AcOK}\right.
$$

The method involves passing $\left[{ }^{18} \mathrm{~F}\right] \mathrm{F}_{2}$ through a column containing a complex of alkali metal acetate with acetic acid. The fluorine-18 reacts, and is retained on the column as $\mathrm{CH}_{3} \mathrm{CO}_{2}{ }^{18} \mathrm{~F}$, which can be removed in an aqueous rinse.

\section{iv. Preparation of Fluorine-18 Labeled Perchloryl Fluoride:}

Perchlorofluoride, $\mathrm{FClO}_{3}$, as an electrophilic reagent will react with unfunctionalized aryllithium compounds, such as phenyl lithium, to produce modest yields of the respective aryl fluorides. (Muchowski and Venuti, 1980) Even so, its general utility as a fluorine-18 labeling agent has never really been fully exploited. Examples where it has been successfully used include the syntheses of $\left[{ }^{18} \mathrm{~F}\right]$-labeled 2fluoroaniline, 2-fluoroanisole, and 3-fluoroveratrole in modest yields. (Ehrenkaufer $e t$ al., 1983a) 


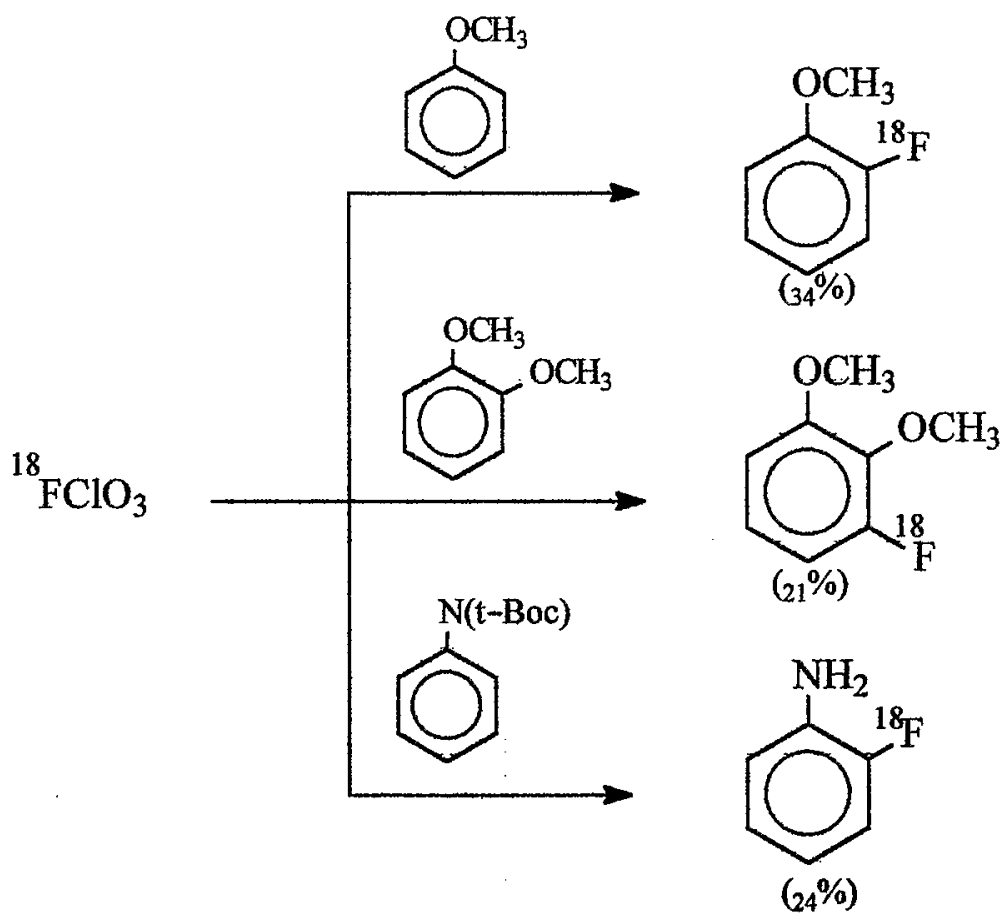

The method for producing $\left[{ }^{18} \mathrm{~F}\right] \mathrm{ClO}_{3}$ involves passing $\left[{ }^{18} \mathrm{~F}\right] \mathrm{F}_{2}$ through a column containing $\mathrm{KClO}_{3}$ maintained at $90^{\circ} \mathrm{C}$.

$$
\left[{ }^{18} \mathrm{~F}^{\mathrm{F}} \mathrm{F}_{2}+\mathrm{KClO}_{3} \stackrel{90^{\circ} \mathrm{C}}{\longrightarrow}{ }^{18} \mathrm{FClO}_{3}+\mathrm{K}^{18} \mathrm{~F}\right.
$$

Rapid on-line purification of the precursor is achieved by passing the effluent from the reaction column through a series of two solid-phase scrubbers containing granular $\mathrm{NaOH}$ and $\mathrm{Na}_{2} \mathrm{~S}_{2} \mathrm{O}_{3}$. These scrubbers must be large enough to effectively remove any unreacted $\mathrm{F}_{2}$ and chlorinated oxides that may form in the $\mathrm{KClO}_{3}$ reaction. Although the reaction is quantitative, only half the radioactivity ends up as $\left[{ }^{18} \mathrm{~F}_{\mathrm{ClO}_{3}}\right.$ with the remainder consumed as $\mathrm{K}\left[{ }^{18} \mathrm{~F}\right]$.

\section{v. Preparation of Fluorine-18 Labeled Xenon Difluoride:}

Like the preceding precursors, $\left[{ }^{18} \mathrm{~F}\right] \mathrm{xenon}$ difluoride, $\left[{ }^{18} \mathrm{~F}\right] \mathrm{XeF}_{2}$, has received only limited attention where its efficacy for synthesizing $\left[{ }^{18} \mathrm{~F}\right]$-2-fluoro-2-deoxy-D-glucose and L- $\left[{ }^{18} \mathrm{~F}\right] 6$-fluorodopa has been demonstrated. (Sood et al., 1983; Firnau et al., 1980) The precursor can be prepared through a couple of approaches. The most common involves the thermal reaction between $\left[{ }^{18} \mathrm{~F}^{\mathrm{F}} \mathrm{F}_{2}\right.$ and xenon gas in a sealed nickel vessel maintained at $390^{\circ} \mathrm{C}$.

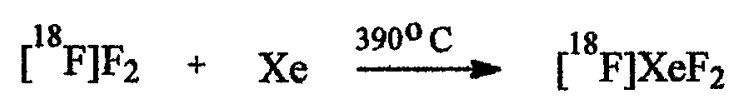

The reaction typically takes 40 minutes to achieve a $70 \%$ yield. However, due to radioactive decay during this reaction time a specific activity of only about 450 $\mathrm{mCi} / \mathrm{mmol}$ is achievable. (Chirakal et al., 1984) A second method involves isotopic exchange between $\mathrm{H}^{18}\left[{ }^{18}\right]$, or some similarly suitable Bronsted or Lewis acid such as 
$\left[{ }^{18} \mathrm{~F}_{\mathrm{SiF}} \mathrm{F}_{4}\right.$ or $\left[{ }^{18} \mathrm{~F}\right] \mathrm{AsF}_{5}$, and $\mathrm{XeF}_{2}$. The reaction involves treating sulfuryl chloride solutions of $\mathrm{XeF}_{2}$ with the radiolabeled acid in fluorinated ethylene propylene vessels. (Schrobilgen et al., 1981) Yields are typically low $(<30 \%)$ and erratic, and precursor specific activity is low. A simpler approach involves $\left[{ }^{18} \mathrm{~F}\right]$ fluoride ion exhange reaction with $\mathrm{XeF}_{2}$ that is catalyzed by the $\mathrm{Cs}^{+}-\mathrm{Kryptofix} 2.2 .2$. complex. (Constantinou et al., 2001) The complex acts to ionize the $\mathrm{XeF}_{2}$ when the reaction is performed in chlorinated solvents such as methylene chloride or chloroform. The catalyzed exchange reaction is much more efficient producing on average $60 \%$ yields of $\left[{ }^{18} \mathrm{~F}\right] \mathrm{XeF}_{2}$ from 50 minutes of reaction at room temperature, but doesn't provide any advantage in specific activity as approximately $50 \mathrm{mg}$ of $\mathrm{XeF}_{2}$ is needed in the exhange.

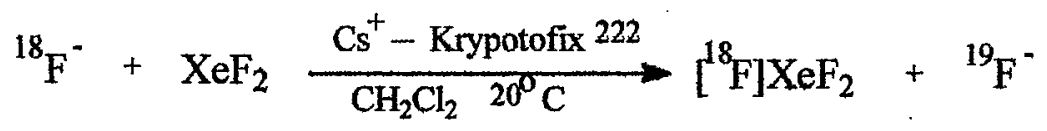

vi. Preparation of Fluorine-18 Labeled N-Fluoropyridinium Triflate:

N-Fluoropyridinium salts have also been investigated as potential fluorine-18 radiolabeling agents. (Oberdorfer et al.,1988a) $\left[{ }^{18} \mathrm{~F}\right]-\mathrm{N}$-Fluoropyridinium triflate was the first, and only, of a potential series of analogous $\mathrm{N}$-fluoro-compounds that was tested. It can be readily prepared by direct reaction between $\left[{ }^{18} \mathrm{~F}_{2}\right.$ and $\mathrm{N}$ trimethylsilylpyridinium triflate in acetonitrile solvent at $-42^{\circ} \mathrm{C}$ yielding $46 \%$ of the radiolabeled precursor with specific activity of $167 \mathrm{mCi} / \mathrm{mol}$.

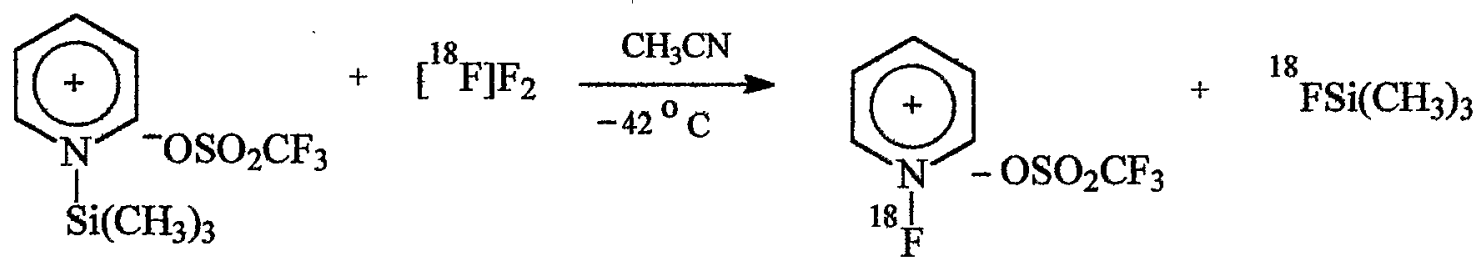

The precursor exhibits high efficiency for reacting with Grignard compounds, related carbanions, and enolates yielding the corresponding $\left[{ }^{18} \mathrm{~F}\right]$-labeled products in high yields. 

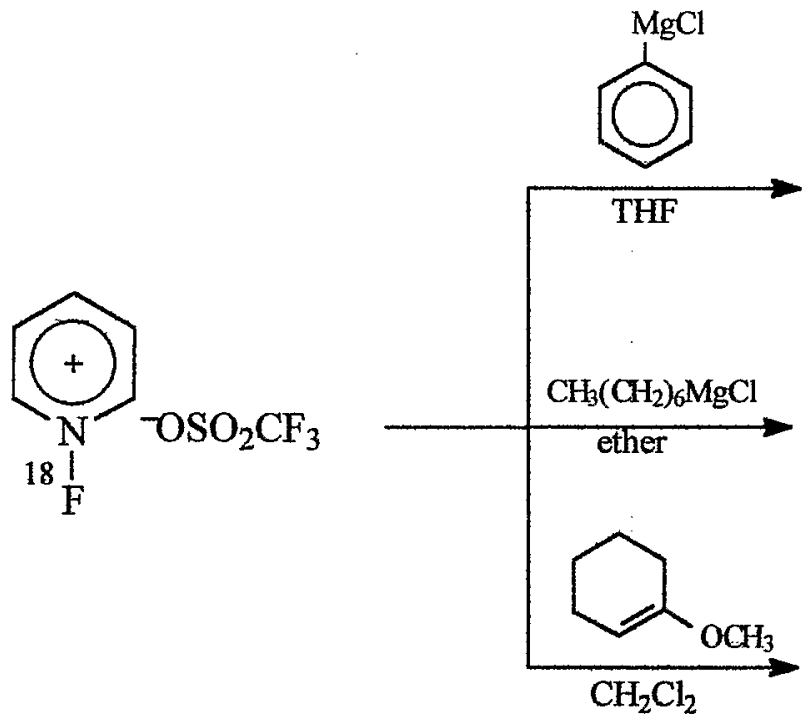<smiles>Fc1ccc(I)cc1</smiles>

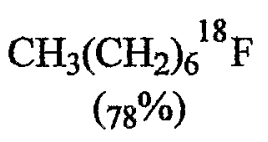<smiles>COC1=C(F)CCCC1</smiles>

$\left(67^{\%}\right)$

vii. Preparation of Fluorine-18 Labeled 1-Fluoro-2-Pyridone:

$1-\left[{ }^{18}\right.$ F]Fluoro-2-pyridone as an electrophilic fluorinating agent also exhibits excellent qualities in terms of its chemical reactivity to undergo efficient ${ }^{18} \mathrm{~F}$-for-metal exchange with organometallic compounds. (Oberdorfer et al., 1988b) For example, reaction of 1- $\left[{ }^{18} \mathrm{~F}\right]$ fluoro-2-pyridone with methyl lithium will yield $\mathrm{CH}_{3}\left[{ }^{8} \mathrm{~F}\right]$ quantitatively.

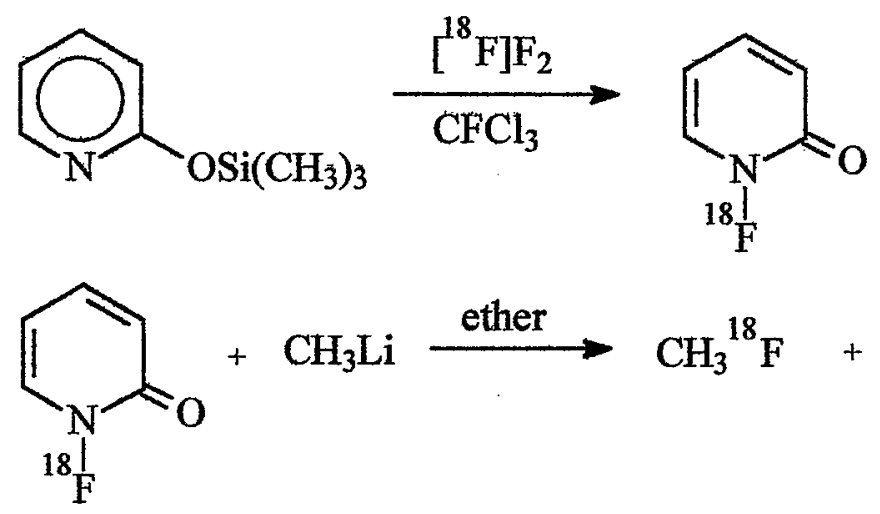<smiles>[13CH3][13CH3]</smiles>

Carrier added 1- $\left[{ }^{18} \mathrm{~F}\right]$ fluoro-2-pyridone can easily be prepared in yields of $40-49 \%$ (out of a maximum possible yield of $50 \%$ ) by bubbling $\left[{ }^{18} \mathrm{~F}\right] \mathrm{F}_{2}$ through a solution of 2(trimethylsiloxy)pyridine in $\mathrm{CFCl}_{3}$, at low temperature. Typically, the process takes about 1 hour which includes the time to irradiate and deliver $\left[{ }^{18} \mathrm{~F}\right] \mathrm{F}_{2}$ to the reaction vessel. The pure precursor is obtained by subliming the crude reaction residue for 30 minutes.

viii. Preparation of Fluorine-18 Labeled N-Fluoro-N-Alkylsulfonamides:

The alkylsulfonamides represents yet another line of "mild" radiofluorinating agents that were developed to regiospecifically react with a variety of carbanions and 
organometallic compounds. (Satyamurthy et al., 1990a) As with the preceding precursors, the sulfonamides are readily labeled with fluorine-18 by bubbling $\left[{ }^{18} \mathrm{~F}\right] \mathrm{F}_{2}$ through a solution of the appropriate sulfonamide in Freon at $-78^{\circ} \mathrm{C}$. Reaction is almost immediate, and the solvent easily removed through evaporation at room temperature. The reaction residue can be taken up in some suitable solvent like ether for subsequent reaction. Typically, $45 \%$ radiochemical yields of the radiolabeled sulfonamide can be obtained, with subsequent reaction carried out in the same vessel in which the precursor was prepared.

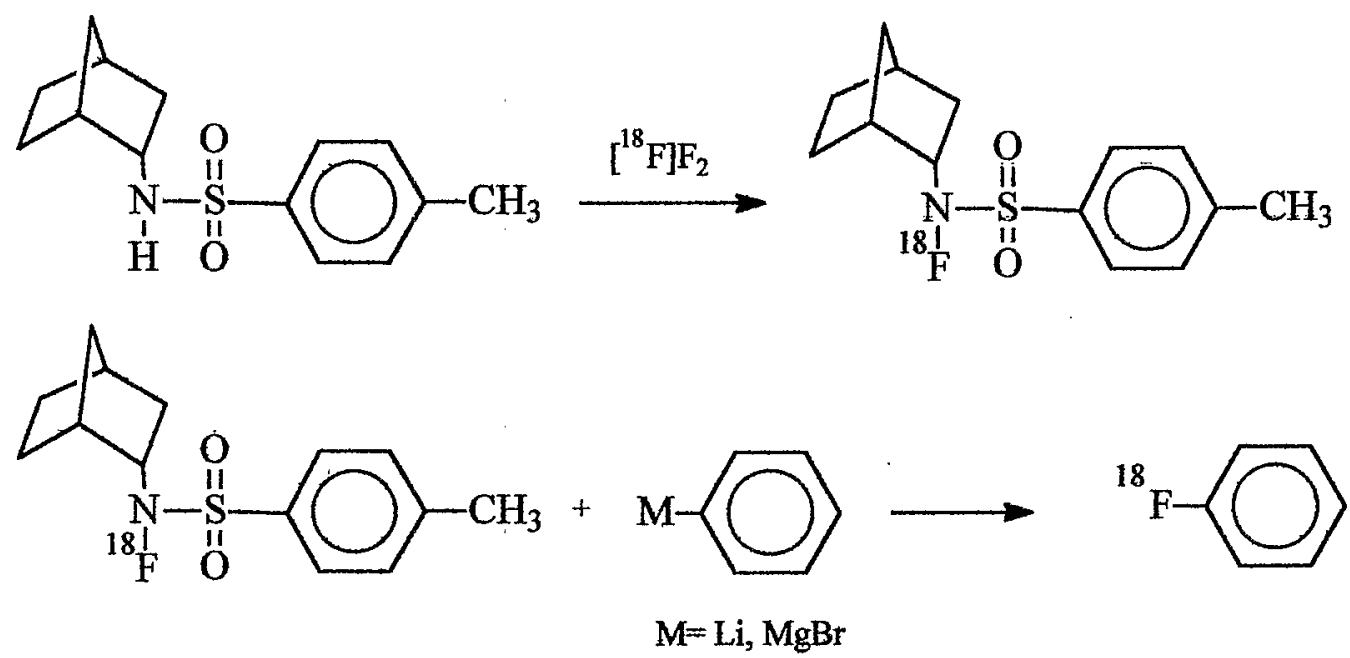

On testing reactivity of various sulfonamides, endonorbornyl-p-tolylsulfonamide exhibited the highest level toward exchange yielding $\left[{ }^{18} \mathrm{~F}\right]$ fluorobenzene in roughly $60 \%$ yield.

\section{Nucleophilic Fluorinating Agents Labeled with Fluorine-18}

\section{i. Preparation of Fluorine-18 Labeled Fluoride Ion:}

Today, radiofluorinations based on nucleophilic processes rely almost exclusively on no-carrier-added $\left[{ }^{18} \mathrm{~F}\right]$ fluoride as the labeling precursor. For years, a number of problems which greatly affected $\left[{ }^{18} \mathrm{~F}\right]$ fluoride reactivity had to be solved in order for radiochemists to successfully move ahead with this precursor. Several papers discuss these issues. (Kilbourn, 1990; Brodack et al., 1986; Gatley et al, 1986; Gatley and Shaughnessy, 1981; Kilbourn et al., 1986; Coenen, 1989)

One key issue is how to render the $\left[{ }^{18} \mathrm{~F}\right]$ fluoride in a suitable solvent that is devoid of an excess of water. Since the method of choice for producing no-carrier-added fluorine-18 is the ${ }^{18} \mathrm{O}(\mathrm{p}, \mathrm{n}){ }^{18} \mathrm{~F}$ reaction on ${ }^{18} \mathrm{O}$-enriched water targets, it is necessary that the fluoride and aqueous media be separated prior to subsequent chemistry. It is worth mentioning that a cryogenic target design relying on a frozen state of ${ }^{18} \mathrm{O}$-enriched carbon dioxide during irradiation generates reasonable yields of fluorine-18, and provides an easy way to separate the target material from the radioisotope after bombardment. (Firouzbakht, et al., 1999b) Essentially, the target material is thawed and the enriched gas recovered leaving the fluorine-18 deposited on the walls. However, even in this instance, 
the $\left[{ }^{18} \mathrm{~F}\right]$ fluoride was recovered through basic aqueous rinses of the target bringing us back to the same issue of anhydrous fluoride.

Typically, most nucleophilic radiofluorinations will tolerate trace levels of water in the reaction medium so it is not essential, and probably next to impossible to render the $\left[{ }^{18}\right.$ F]fluoride entirely anhydrous. Simple distillation of the aqueous phase can lead to two problems. On the one hand, recovery of the enriched water while maintaining isotopic purity may not be effective. More importantly, distillation can lead to a concentration of anionic and cationic contaminants from the target materials that can influence reactivity of the $\left[{ }^{18} \mathrm{~F}\right]$ fluoride. (Nickles et al., 1986) Cations, especially $\mathrm{Al}^{3+}$ and $\mathrm{Ca}^{2+}$, will probably impinge on reactivity the most.

A number of procedures have been described for isolating $\left[{ }^{18} \mathrm{~F}\right]$ fluoride and target water that render it in suitable reaction media. Typically, the target water is processed through an ion exchange resin that provides a means not only to recover the target water, but also a way to remove some of the target water ion contaminants that can impact on reactivity. One way involves using Dowex AG1-X8 anion exchange resin. (Schlyer et al., 1987; Jewett et al., 1988; Schlyer et al., 1990) Interestingly enough, this resin seems to have a high affinity for metal cations, as well. Extensions of this approach have also been described. One includes using quanternary ammonium resins for isolation of the $\left.{ }^{18} \mathrm{~F}\right]$ fluoride from the target water, as well as for creating a reactive nucleophilic media for subsequent chemistry. (Mulholland et al., 1988; Mulholland et al., 1989) Additionally, a supported aminopolyether can be used to a similar extent as the quanternary ammonium resin with perhaps some enhancement of fluoride reactivity. (Hamacher et al., 1990) Finally, $\left[{ }^{18} \mathrm{~F}\right]$ fluoride can be extracted from target water using a potassium ion/cryptand complex immobilized on a stationary support. (Jewett et al., 1988) Two other approaches are worth mentioning because they don't rely on a trapping agent to achieve separation of the radioisotope and target water. One method utilizes electrochemical deposition as a means to achieve reasonable extraction efficiency of $\left[{ }^{18}\right.$ F]fluoride from target water. (Alexoff et al., 1989) By controlling the polarity on an applied potential across an electrochemical cell, it is possible to selectively deposit $\left[{ }^{18}\right.$ F]fluoride on the cell's walls and later remove it with reasonable efficiency. Unfortunately, the technique has not found wide-spread acceptance. The other method involves chemically converting the $\left[{ }^{18} \mathrm{~F}\right]$ fluoride into gaseous $\left[{ }^{18} \mathrm{~F}\right]$ fluorotrimethylsilane to achieve separation. The gas can be trapped in near anhydrous acetonitrile and hydrolyzed back to fluoride using a small amount of base. (Gatley, 1989)

Another key issue is how to maintain $\left[{ }^{18} \mathrm{~F}\right]$ fluoride solubility. Without a doubt this is the most important requirement for successful nucleophilic radiofluorinations. A counterion is usually required that possesses sufficient solubility within the reaction media to maintain fluoride solubility, as well. Typically, $\left[{ }^{18} \mathrm{~F}\right]$ fluoride is extracted from the anion exchange resin using a dilute alkali metal carbonate solution. Typically, potassium carbonate is preferred. However, the $\mathrm{K}^{+}$counterion possesses limited solubility in some reaction solvents. Larger alkali metals such as cesium or rubidium do offer some enhancement to fluoride solubility although they are still limited in some respects. Even so, these salts have been successfully used in a number of radiofluorinations. (Shiue et al., 1985; Shiue et al., 1986a; Shiue et al., 1986b)

A number of alternate methodologies have been investigated to provide enhancement to solubility, as well as to reactivity. Some of these involve adding complexing agents to enhance cation solubility, while others explore different cations altogether. For example, addition of 18 -crown-6 ether will greatly improve $\left[{ }^{18} \mathrm{~F}\right]$ fluoride 
reactivity in certain instances such as radiofluorinating progesterone. (Irie et al., 1982; Irie et al., 1984) Use of aminopolyether Kryptofix 2.2.2. as a complexing agent will also improve $\mathrm{K}^{+}$solubility, and greatly enhance nucleophilic radiofluorinations with $\left[{ }^{18} \mathrm{~F}\right]$ fluoride on both aliphatic and aromatic substrates. Examples of successful radiofluorinations include the preparation of $\left[{ }^{18} \mathrm{~F}\right]$-2-deoxy-D-mannose, $\left[{ }^{18} \mathrm{~F}\right]$-2-deoxy-Dglucose, $\left[{ }^{18} \mathrm{~F}\right]-\mathrm{N}$-methylspiperone, $\left[{ }^{18} \mathrm{~F}\right]$-spiperone, as well as $\left[{ }^{18} \mathrm{~F}\right]$-aliphatic carboxylic acids. (Block et al., 1986; Coenen, et al., 1986a; Hamacher et al., 1986a; Hamacher et al., 1986b; Hamacher et al., 1986c) A good choice for alternate cations includes the tetraalkylammonium salts, $\mathrm{R}_{4} \mathrm{~N}^{+}(\mathrm{R}=$ methyl, ethyl or butyl). These salts are extremely proficient at promoting nucleophilic radiofluorinations without the need for additional complexing agents. They also offer greater utility in terms of their ability to remain solubilize in a variety of solvent classes. (Kiesewetter et al., 1986)

\section{ii. Preparation of Fluorine-18 Labeled Hydrogen Fluoride:}

Fluorine-18 labeled hydrogen fluoride, $\left.\mathrm{H}^{18} \mathrm{~F}\right]$, can be used in nucleophilic radiofluorinations of aromatic compounds by the Schiemann or triazene decomposition reactions although the former requires the presence of carrier, and neither reaction is terribly efficient. (De Kleijn, 1977; $\mathrm{Ng}$ et al., 1981; Barrio et al., 1983; Berridge et al., 1985; Satyamurthy et al., 1990b)

Shortly after the development of the neon gas target for $\left[{ }^{18} \mathrm{~F}\right] \mathrm{F}_{2}$ production using the ${ }^{20} \mathrm{Ne}(\mathrm{d}, \alpha)^{18} \mathrm{~F}$ nuclear reaction, researchers quickly realized that in the absence of any reactive scavenging gas, the fluorine-18 remains trapped to the inside walls of the target. This phenomenon can be exploited as a way to prepare large quantities of presumably anhydrous $\left.\mathrm{H}^{18} \mathrm{~F}\right]$ for nucleophilic radiofluorinations. This process, however, involves heating the target after irradiation up to $1000^{\circ} \mathrm{C}$ while flushing hydrogen gas through it. (Winchell, 1976) The hydrogen gas reacts with the surface bound fluorine-18, and allows it to be harvested as $\left.\mathrm{H}^{18} \mathrm{~F}\right]$. A similar strategy can be applied to irradiations of oxygen-18 enriched $\mathrm{O}_{2}$ gas. Unfortunately, the rigors of heating a metal target to such extreme temperatures will eventually take their toll on target surface morphology, as well as on target hardware. A more practical approach involves the addition of hydrogen gas to the target during the irradiation. Non-heated recirculating gas targets work, but only generate modest amounts of $\left.\mathrm{H}^{18}{ }^{18} \mathrm{~F}\right](20-30 \mathrm{mCi})$. (Tewson and Welch, 1980; Levy et al., 1982) By combining the features of heating the target during the irradiation along with adding hydrogen gas to the neon will produce much larger amounts of $\mathrm{H}\left[{ }^{18} \mathrm{~F}\right]$. (Blessing et al., 1986; Clark and Buckingham, 1982; Ehrenkaufer et al, 1983b; Kilbourn et al., 1982) The advantage here is that the target doesn't have to be heated to such extreme temperatures as in the post-irradiation treatment described above. Even so, this approach is not terribly dependable for consistent recovery of no-carrier-added $\left.\mathrm{H}^{18}{ }^{18} \mathrm{~F}\right]$. Improved reliability can be achieved, at the cost of specific activity, through the addition of small amounts of carrier HF. Even so, controlling the amount of carrier introduced is not trivial. Anhydrous $\mathrm{HF}$ gas is highly corrosive requiring suitable valves and plumbing to safely manipulate small amounts of the material. A variation on this strategy uses mixtures of $\mathrm{CF}_{4}$ and $\mathrm{H}_{2}$ in neon. Small but adequate amounts of carrier $\mathrm{HF}$ are generated in situ presumably through radiolysis. (Ferrieri et al., 1982) 


\section{Preparation of Fluorine-18 Labeled Alkylating Agents}

Direct nucleophilic substitution with no-carrier-added $\left[{ }^{18} \mathrm{~F}\right]$ fluoride is often difficult and sometimes even impossible to carry out in certain complex molecules. A classic example is the aryl radiofluorination of phenolic compounds. Due to the acidity of the phenolic hydrogen, abstraction of hydrogen by fluoride will dominate over substitution. Researchers quickly realized that there was a need to expand the arsenal of radiofluorinating agents beyond the scope of the simple electrophilic precursors, and "naked" fluoride. An alternate labeling strategy evolved for introducing fluorine-18 onto larger molecules by first attaching the radioisotope to a prosthetic group. One of the first areas to be developed involved the preparation and application of bifunctional $\left[{ }^{18} \mathrm{~F}\right]$ fluoroalkanes. The intent here was to replace radiopharmaceuticals labeled with $\left[{ }^{11}\right.$ C]alkyl iodides with near equivalent compounds labeled with longer-lived fluorine-18.

$$
\begin{gathered}
\left(\mathrm{CH}_{2}\right)_{\mathrm{n}} \mathrm{X}^{18} \mathrm{~F}+\mathrm{R}-\mathrm{Z}-\mathrm{H} \underset{\mathrm{Z}=\text { functional groups containing } \mathrm{N}, \mathrm{O}, \mathrm{S} \text { or } \mathrm{C}}{\mathrm{n}=\mathrm{R}-\mathrm{Z}} \underset{\mathrm{C}=\mathrm{CH}}{\mathrm{X}=\mathrm{Cl}, \mathrm{Br}, \mathrm{I}} \\
\end{gathered}
$$

No-carrier-added $\mathrm{CH}_{2} \mathrm{Br}\left[{ }^{18} \mathrm{~F}\right]$ was the first to be prepared in this class of precursor. (Coenen et al., 1986b) It can be readily prepared by exchange of ${ }^{18} \mathrm{~F}$-for-Br through nucleophilic substitution of $\left[{ }^{18} \mathrm{~F}\right]$ fluoride with $\mathrm{CH}_{2} \mathrm{Br}_{2}$. Typically, the reaction is carried out in anhydrous acetonitrile at $115^{\circ} \mathrm{C}$, and the volatile radiolabeled product collected cryogenically using liquid nitrogen. The trick to getting an efficient reaction here is to render the fluorine-18 in a reactive form. As described earlier, this is readily accomplished by adding potassium carbonate and aminopolyether Kryptofix 2.2.2. as a complexing agent to the aqueous phase containing the fluorine-18. Yields of $62 \%$ can be attained in this fashion.

More recently $\left[{ }^{18} \mathrm{~F}\right]$ fluoromethyl iodide, $\mathrm{CH}_{2} \mathrm{I}\left[{ }^{18} \mathrm{~F}\right]$, was prepared using much the same strategy as described above where reactive $\left[{ }^{18} \mathrm{~F}\right]$ fluoride is mixed with diiodomethane. (Zheng and Berridge, 2000) Although yields are not as high (40\% in 15 minutes time) as the bromide form, an advantage here is that cryogenic trapping of the precursor does not have to be as rigorous. A dry ice bath at $-20^{\circ} \mathrm{C}$ will perform nicely. A number of applications for labeling with $\mathrm{CH}_{2} \mathrm{I}\left[{ }^{18} \mathrm{~F}\right]$ have also been tested and it seems that the iodo form is slightly more reactive toward $\mathrm{SN}_{2}$ reactions. 


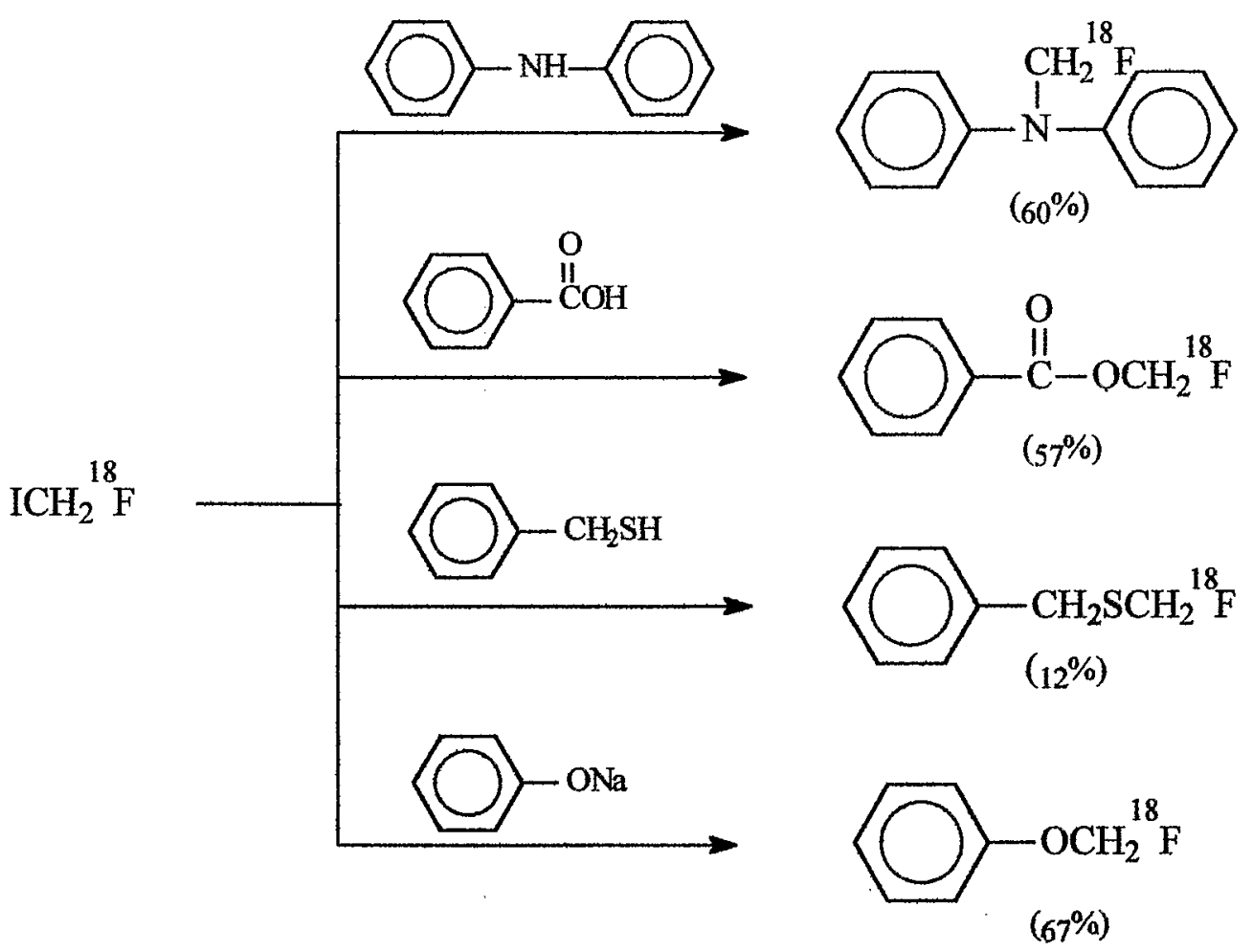

This class of precursor was quickly expanded to include $\left[{ }^{18} \mathrm{~F}\right]$ fluoroalkanes with larger carbon side-chains. However, the size of the alkyl side-chain, as well as the nature of the leaving group, can strongly influence the nucleophilic substitution yield where higher yields are usually obtained for larger side-chains, and for a sequence of leaving groups $\mathrm{Br}<$ mesyl < tosyl.(Block et al., 1987) The choice of starting material for larger side-chains is somewhat independent of the leaving substituent, and can be made on the basis of commercial availability. It should be noted, however, that symmetrical bistosyloxyalkanes offer a greater advantage with respect to the stability of the educts and the fluorinated products when compared to the respective halides. Even so, the number of successful applications of $\mathrm{N}$-alkylation of neurotransmitter receptor active amides and amines using $\left[{ }^{18} \mathrm{~F}\right]$ fluoroalkyl halides suggests that these precursors can work equally well in many circumstances. (Shiue et al., 1987) Examples below illustrate that radiolabeling of $\mathrm{N}-\left(3-\left[{ }^{18} \mathrm{~F}\right]\right.$ fluoropropyl)lorazepam and $\mathrm{N}-\left(2-\left[{ }^{18} \mathrm{~F}\right]\right.$ fluoroethyl) and $\mathrm{N}-(2$ $\left[{ }^{18} \mathrm{~F}\right]$ fluoroproyl) spiroperidols by this approach can be accomplished with very good yields. 


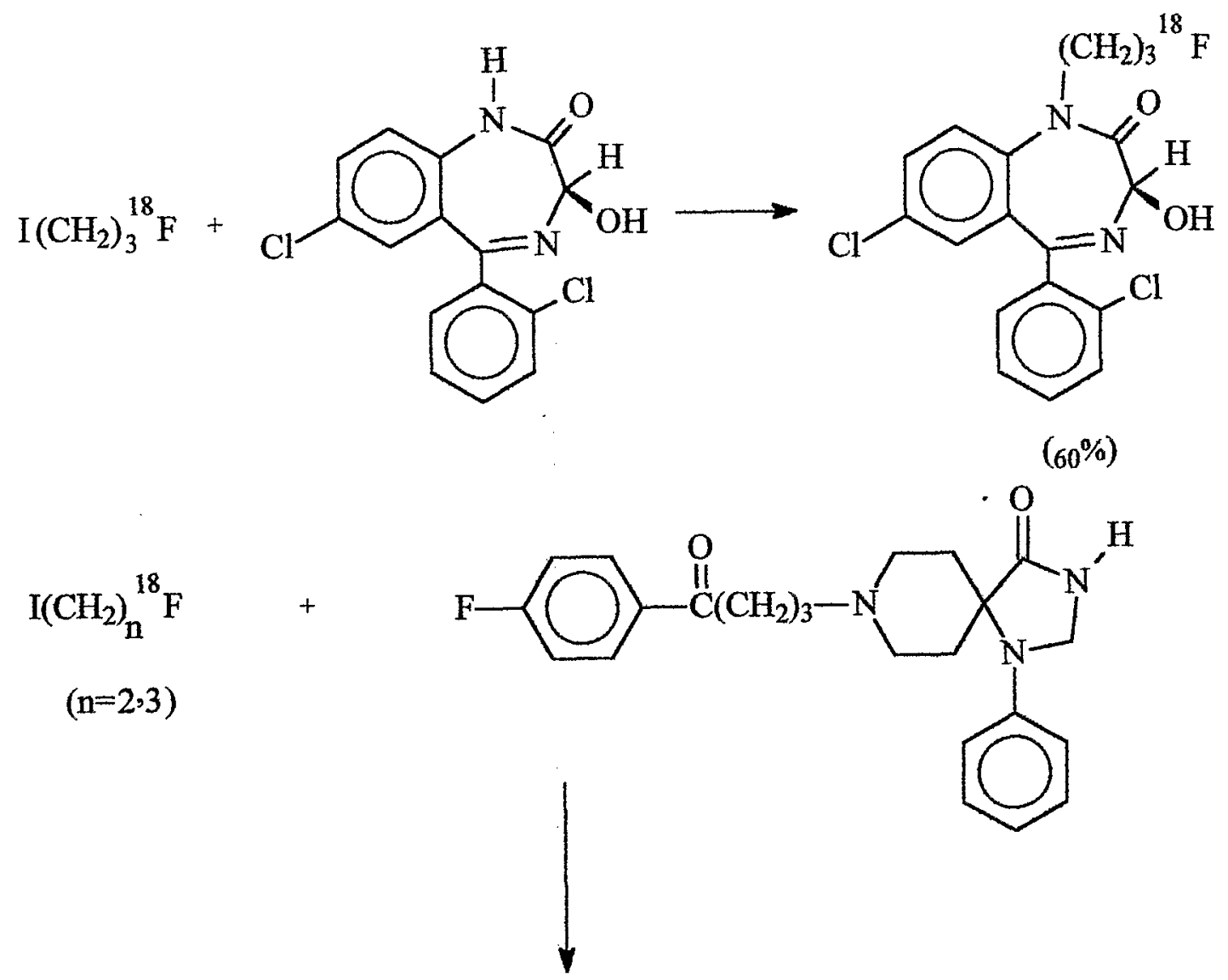<smiles>NCCCN1CN(c2ccccc2)C2(CCN(CCC(=O)c3ccc(F)cc3)CC2)C1=O</smiles>

Successful radiofluorination of $\mathrm{H}$-acidic compounds can also be carried out using $\left.{ }^{18} \mathrm{~F}\right]$ fluoroalkylating agents. (Block et al., 1988a) As mentioned earlier, compounds in this class, such as the phenols, can not be radiofluorinated with "naked" fluoride. However, it is possible to accomplish this task in high yields using suitable $\left[{ }^{18} \mathrm{~F}\right]$ fluoroalkylating agents. In this instance, the best no-carrier-added labeling yields are obtained using tosylates as leaving groups.

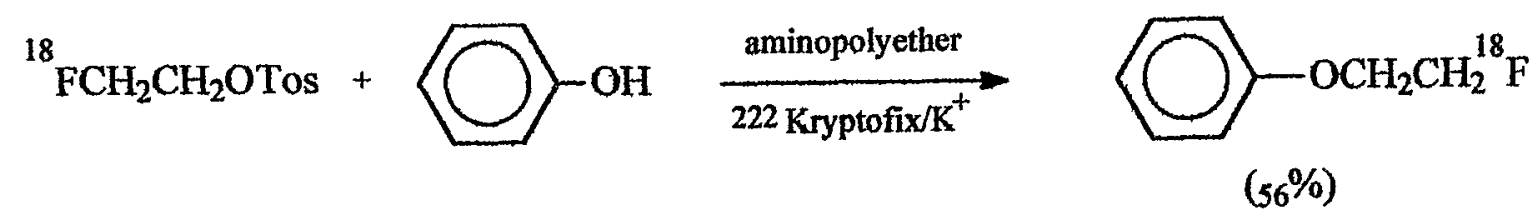


The trifluoromethylsulfonates (triflates) are also good leaving groups for inducing efficient nucleophilic exchange with $\left[{ }^{18} \mathrm{~F}\right]$ fluoride to yield the respective $\left[{ }^{18} \mathrm{~F}\right]$ alkylating agent. Both 3-bromopropyl-1-triflate and 3-iodopropyl-1-triflate can be used as starting materials for preparing useful amounts of the labeling precursors, $3-\left[{ }^{18} \mathrm{~F}\right]$ fluoropropyl bromide and 3-[ $\left[{ }^{18} \mathrm{~F}\right]$ fluoropropyl iodide. Their usefulness in radiofluorinations has been demonstrated in the labeling of several diprenorphine derivatives, (Chesis and Welch, 1990) of certain dopamine D-1 and benzodiazepine receptor radioligands, (Teng et al., 1990) as well as in the labeling of certain derivatives of spiperone. (Oh et al., 1999)

\section{E. Preparation of Fluorine-18 Labeled Acylating Agents}

Developments in radiolabeled peptides and antibody fragments possessing relatively fast in vivo kinetics for receptor and immunoimaging quickly lead to a need for ways to radiofluorinate large biologically active molecules at no-carrier-added levels. While radiofluorination of peptides by electrophilic fluorination has been shown to proceed with reasonable efficiency, the process requires carrier fluorine which is not tolerable in many instances. (Hebel et al., 1990) Chemists turned their attention to developing a new class of labeling precursor based on no-carrier-added $\left[{ }^{18} \mathrm{~F}\right]$ fluoroacylating agents. Agents in this class include $\left[{ }^{18} \mathrm{~F}\right]$ fluorocarboxylic acids, their esters and the acid halides.

In the early stages of development, fluoroacylation with no-carrier-added 2$\left[{ }^{18} \mathrm{~F}\right]$ fluoropropionic acid methylester was successfully applied to primary alcohols and amines. (Block et al., 1988b)

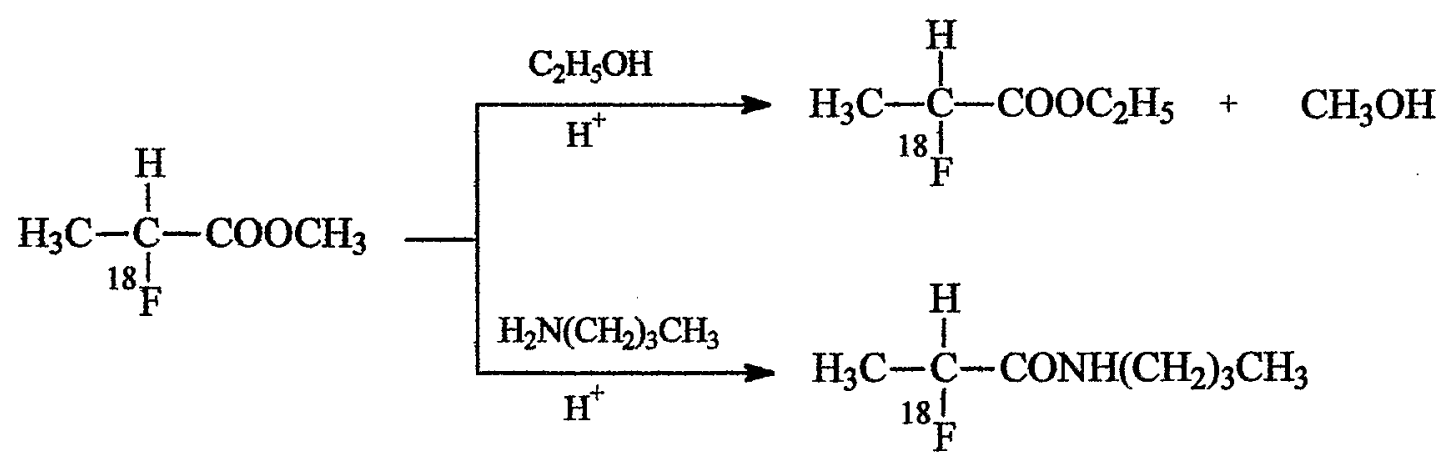

This synthetic scheme can be optimized for reactions with amines by incorporating an additional step to convert the ester to its free acid form using base mixed with dicyclohexylcarbodiimide.

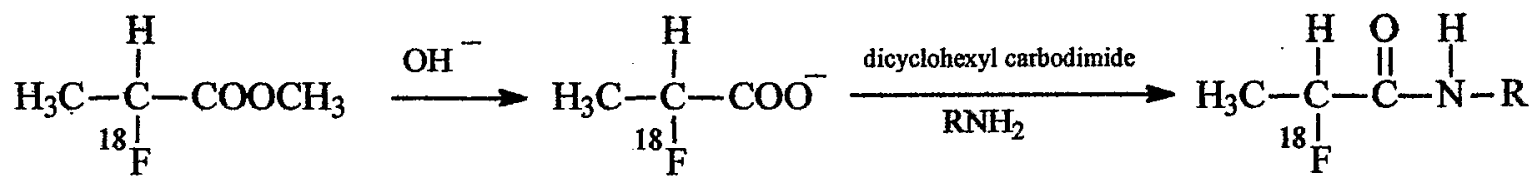


The preparation of $2-\left[{ }^{18} \mathrm{~F}\right]$ fluoropropionic acid methylester is similar to what has already been described for the $\left[{ }^{18} \mathrm{~F}\right]$ fluoroalkylating agents. Activation by the aminopolyether 2.2.2. $/ \mathrm{K}_{2} \mathrm{CO}_{3}$ complex is used for the nucleophilic fluorine-18 exchange in $\alpha$-substituted acid esters. Increasing yields for formation of the precursor are found with the sequence of leaving groups: $\mathrm{I}<<\mathrm{Cl}<\mathrm{Tos}<\mathrm{Br}$.

Unfortunately, there are limitations to this approach to radiofluorination of peptides and proteins or even non-biological compounds of interest. The proficiency for the $\left[{ }^{18} \mathrm{~F}\right]$ fluoropropionic acid methylester precursor to radiolabel secondary alcohols and amines is considerably less than on primary substrates. In addition, it has not been possible to sustain efficient nucleophilic substitutions on smaller acid moieties such as the highly activated esters of bromoacetic acid. This shortcoming, however, can be overcome using a variation involving activated esters and imidazolides of $\left[{ }^{18} \mathrm{~F}\right]$ acetic acid or $\left[{ }^{18} \mathrm{~F}\right]$ propionic acid, but at the expense of increased complexity to the radiosynthesis. (Guhlke et al., 1994)

Additional applications for labeling monoclonal antibodies with ${ }^{18} \mathrm{~F}$ can be found utilizing radiolabeled acylating agents such as the $\left[{ }^{18} \mathrm{~F}\right]-\mathrm{N}$-succinimidyl 8-(4fluorobenzyl)amino substrates, (Garg et al., 1991) and $\left[{ }^{18} \mathrm{~F}\right]-\mathrm{N}$-succinimidyl 4fluorobenzoate (Vaidyanathan and Zalutsky, 1992) that are prepared from 4$\left[{ }^{18} \mathrm{~F}\right]$ fluorobenzoic acid. The process for radiolabelling the benzoic acid involves $\left[{ }^{18} \mathrm{~F}\right]$ fluoride substitution for trimethylammonium group on 4-formyl-N,N,Ntrimethylanilinium triflate followed by oxidation to the acid. More recently, a greatly simplified one-step synthesis of $\left[{ }^{18} \mathrm{~F}\right]-\mathrm{N}$-succinimidyl 4-(fluoromethyl)benzoate was reported that involved nitro substitution using Kryptofix $2.2 .2 /\left[{ }^{18} \mathrm{~F}\right]$ and $\mathrm{N}$-succinimidyl4-[(4-nitrobenzensulfonyl)oxymethyl]benzoate)benzoate to produce the acylating agent in a radiochemical yield of $18 \%$ within 30 minutes. (Lang and Eckelman, 1994)

\section{F. Fluorine-18 Labeled Fluoroaryl Precursors}

A number of no-carrier-added fluorine-18 labeled aromatic compounds can be made that add enormous versatility in the chemist's arsenal of labeling synthons to allow him to tackle rather complex mult-step syntheses of radiopharmaceuticals successfully. No-carrier-added synthesis of many of these key intermediates usually involves nucleophilic aromatic substitution. This process most often proceeds with high efficiency, and in high yield for radiofluorinations involving $\left[{ }^{18} \mathrm{~F}\right]$ fluoride ion displacement of either a nitro group, halogen atom or a $\mathrm{N}^{+}\left(\mathrm{CH}_{3}\right)_{3}$ group on an aromatic ring that is activated by some strongly electron-withdrawing function such as a cyano, nitro or keto group. (Angelini et al., 1985; Attina et al., 1983; Shiue et al., 1984) It has been possible to use this reaction in the presence of electron-donating groups. (Ding et al., 1990)

\section{i. Preparation of $\left[^{18}\right.$ Flfluorobenzaldehydes:}

${ }^{18}$ F]Fluorobenzaldehydes are regarded as extremely useful precursors not only for their ability to produce other radiofluorinating agents such as $\left[{ }^{18} \mathrm{~F}\right]$ benzyl alcohols and $\left[{ }^{18} \mathrm{~F}\right]$ benzyl halides, but also because they can be used directly in the preparation of some rather complex radiopharmaceuticals. $4-\left[{ }^{18} \mathrm{~F}\right]$ Fluorobenzaldehyde was first successfully 
used for the synthesis of the amino acid D,L-4- $\left[{ }^{18} \mathrm{~F}\right]$ fluoroalanine. (Lemaire et al., 1987) Other examples using either $4-\left[{ }^{18} \mathrm{~F}\right]$ fluorobenzaldehyde or $6-\left[{ }^{18} \mathrm{~F}\right]$ fluoropiperonal include the radiolabeling of L-6- $\left[{ }^{18} \mathrm{~F}\right]$ fluorodopa (Lemaire et al., 1990), L-4- $\left[{ }^{18} \mathrm{~F}\right]$ fluorotyrosine (Lemaire et al., 1991), the MAO inhibitor $\left[{ }^{18} \mathrm{~F}\right]$ fluorodeprenyl (Plenevaux et al., 1991), as well as the false adrenergic transmitter $\left[{ }^{18} \mathrm{~F}\right]$ fluoronoreprinephrine. (Ding et al., 1991) Reductive amination of these fluoroaldehydes in the presence of suitable secondary amines can also be a good source of radiopharmaceuticals possessing a benzyl amino group. $\left[{ }^{18} \mathrm{~F}\right]$ Fluorotropapride, a $\mathrm{D}_{2}$ antagonist, is prepared in this manner. (Damhaut et al., 1991) Oxidation of $\left[{ }^{18} \mathrm{~F}\right]$ fluorobenzaldehydes by the Baeyer-Villiger reaction followed by dealkylation using boron tribromide will also produce $\left[{ }^{18} \mathrm{~F}\right]$ fluorocatechol. (Chakraborty and Kilbourn, 1991)

$\left[{ }^{18}\right.$ F] Fluorobenzaldehyde is typically prepared in high yield by radiofluorination of o- or p-nitrobenzaldehyde using $\left[{ }^{18} \mathrm{~F}\right]$ fluoride activated with Kryptofix $2.2 .2 . / \mathrm{K}^{+}$as a complexing agent. (Lemaire et al., 1987; Lemaire et al., 1992)
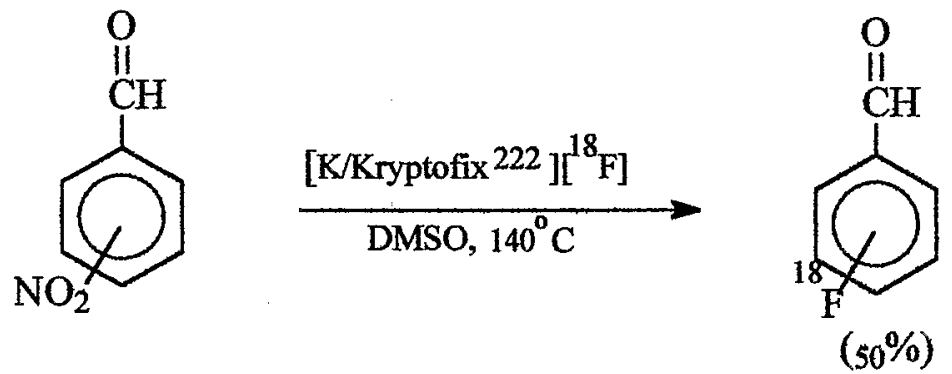

The reaction is typically carried out in $1 \mathrm{~mL}$ DMSO solvent using about $15 \mathrm{mg}$ of the corresponding nitroaldehyde. Reaction time is 20 minutes with heating in a closed vessel at $130-140^{\circ} \mathrm{C}$. The crude product is purified using a C-18 Sep Pak to extract the product and tetrahydrofuran or some suitable solvent to eventually extract the aldehyde for subsequent reaction. Radiofluorination yields in this step are usually $>50 \%$.

\section{ii. Preparation of $~^{18}{ }^{18}$ Flfluorobenzylalcohols:}

The $\left[{ }^{18} \mathrm{~F}\right]$ fluorobenzylalcohols are important only in the sense that they are key intermediates to generating $\left[{ }^{18} \mathrm{~F}\right]$ fluorobenzylhalides. These compounds are prepared from their respective $\left[{ }^{18} \mathrm{~F}\right]$ fluorobenzaldehydes using the procedures described above. However, purification of the radiofluorinated aldehyde is not necessary after the first step of the reaction as reduction to the alcohol can be carried out in the same vessel. The contents must be cooled, however, at the end of the first step after which $10 \mathrm{mg}$ $\mathrm{NaBH}_{3} \mathrm{CN}$ and a trace of bromocresol green are added. The mixture must also be made acidic (pH 4) typically by adding dilute $\mathrm{HCl} /$ methanol. (Hatano et al., 1991) Reduction using lithium aluminum hydride is also possible, but the added complexity to render the $\left[{ }^{18} \mathrm{~F}\right]$ fluorobenzaldehyde anhydrous, as well as devoid of DMSO creates much more complexity than is needed. A third approach is appealing because of its simplicity. The method uses solid-phase reduction involving a small column of $\mathrm{NaBH}_{4}$ supported on aluminum oxide. (Lemaire et al., 1991) The reaction contents from the $\left[{ }^{18} \mathrm{~F}\right]$ fluorobenzaldehyde synthesis are simply passed through a potassium carbonate drying tube before entering the reduction column. The $\left[{ }^{18} \mathrm{~F}\right]$ fluorobenzyl alcohol is directly recovered from the column using THF solvent. 


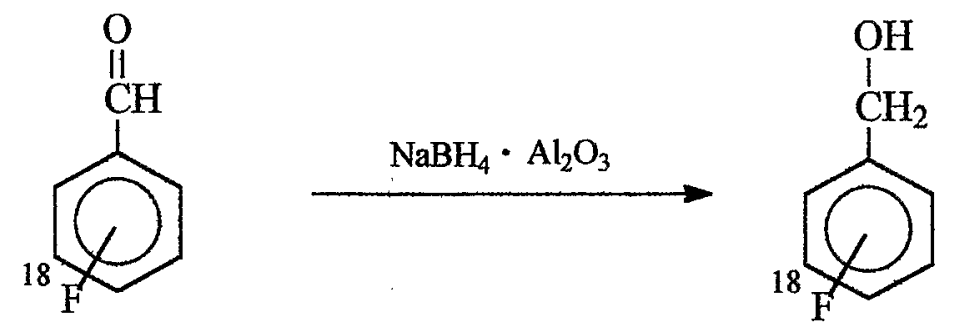

iii. Preparation of $\left[^{18}\right.$ F]fluorobenzylhalides:

Within the class of $\left[{ }^{18} \mathrm{~F}\right]$ fluoroaryl precurors, the $\left[{ }^{18} \mathrm{~F}\right]$ fluorobenzylhalides are perhaps the most versatile in the sense that they provide a widest range of useful radiopharmaceuticals by simple $\left[{ }^{18} \mathrm{~F}\right]$ fluorbenzylation. The usefulness of $\left[{ }^{18} \mathrm{~F}\right]$ fluorobenzylations in radiopharmaceutical synthesis was first demonstrated with the preparation of several radiolabeled benzamide neuroleptics that exhibited high specific binding toward $\mathrm{D}_{2}$-dopamine receptors in vivo (Hatano et al., 1991) In addition, several other receptor ligands have been prepared by this approach including 2- and 4$\left[{ }^{18} \mathrm{~F}\right]$ fluorotropaprides (Damhauat $e t$ al., 1992), $\left[{ }^{18} \mathrm{~F}\right] \mathrm{NCQ} 115$ (Halldin $e t$ al., 1994), and $p-\left[{ }^{18} \mathrm{~F}\right]$ fluorobenzyltrozamicol. (Efange et al., 1994)

$\left[{ }^{18}\right.$ F]Fluorobenzyl halides can be prepared in a number of ways, most of them involving complicated multi-step reactions. All begin with the preparation of a $\left[{ }^{18}\right.$ F]fluorobenzaldehyde using the methods described above. From this point one of four ways can be used to convert the fluoroaldehyde into the appropriate fluorobenzyl halide. The first three methods require a reduction step to convert the aldehyde to the corresponding alcohol. The best ways to accomplish this task have already been described in the preceding section under $\left[{ }^{18} \mathrm{~F}\right]$ fluorobenzyl alcohols. In the first method, which was tailored for making $4-\left[{ }^{18} \mathrm{~F}\right]$ fluorobenzyl iodide, the $\left[{ }^{18} \mathrm{~F}\right]$ fluorobenzaldehyde is reduced to the alcohol using a solution of lithium aluminum hydride in THF solvent. (Mach et al., 1993) As mentioned earlier, care must be taken to remove excess water and DMSO solvent from the proceeding reaction. Reduction occurs rapidly and efficiently at room temperature with adequate stirring, after which the solvent is evaporated. The radiofluorinated alcohol remains complexed as the lithium salt. Hydrolysis of the salt and iodination of the free alcohol is accomplished using hydroiodic acid (57\%) and reaction for 3 minutes at $90^{\circ} \mathrm{C}$. This can be carried out in the same reaction vessel as that used in the aldehyde reduction. After the iodination reaction, the crude product is purified through extraction with a C-18 Sep Pak. A variation on this approach uses hydrobromic acid, $\mathrm{HBr}$, in place of the hydroiodic acid to make $\left[{ }^{18} \mathrm{~F}\right]$ fluorobenzyl bromide. (Hatano et al., 1991)

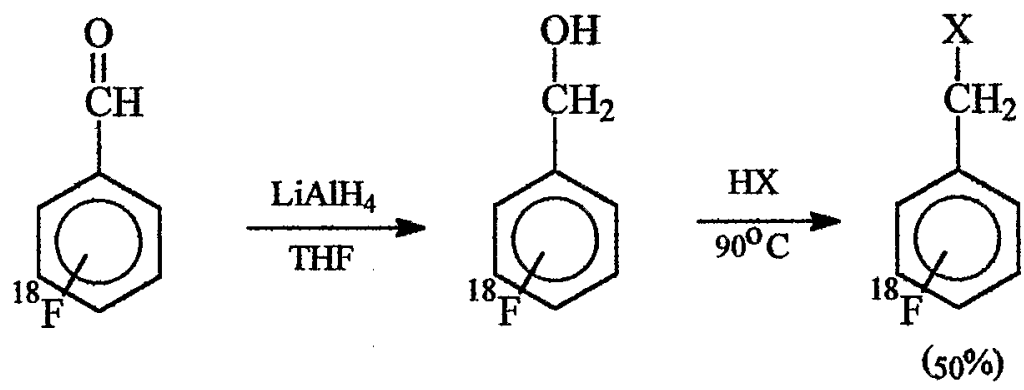


In the second method, either thionyl chloride or thionyl bromide can be used in place of hydroiodic or hydrobromic acids to convert the alcohol to the corresponding halide. (Hwang et al., 1991; Damhaut et al., 1992) This method offers a slight advantage over the previous one in that the THF solvent used either in the reduction step or in the $\left[{ }^{18} \mathrm{~F}\right]$ fluorobenzyl alcohol extraction does not have to be evaporated to dryness. Volumes are reduced slightly and reaction carried out for $1-2$ minutes at $110^{\circ} \mathrm{C}$ in a sealed vessel. Yields on average are slightly less than the previous method, but certainly adequate.

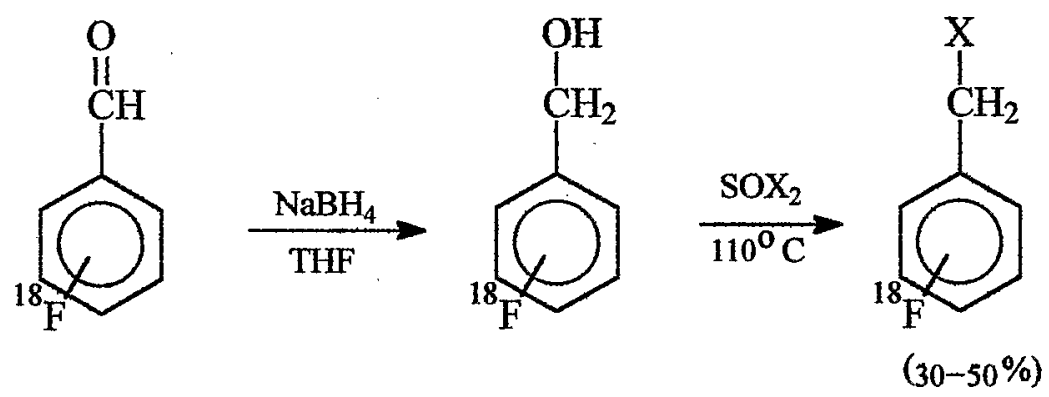

A third method involves direct reductive iodination of $\left[{ }^{18} \mathrm{~F}\right]$ fluorobenzaldehyde using diiodosilane, $\mathrm{SiH}_{2} \mathrm{I}_{2}$. (Lemaire et al., 1994; Dence et al., 1997) While the method does eliminate the need for an intermediate reduction step, one must still isolate the aldehyde from the DMSO solvent prior to the iodination step.<smiles>O=Cc1cccc(CI)c1</smiles>

The last method offers one key advantage over the other methods in that the processes are greatly simplified by utilizing a solid-phase reaction in the reduction step followed by halogenation using dihalotriphenylphosphine, $\mathrm{PH}_{3} \mathrm{PX}_{2}(\mathrm{X}=\mathrm{Br}, \mathrm{l})$. The entire process is amenable to system automation requiring about 30 minutes. (Iwata et al., 2000) Once the $\left[{ }^{18} \mathrm{~F}\right]$ fluorobenzaldehyde is made it is reduced to the alcohol using a solid-phase reaction involving alumina supported $\mathrm{NaBH}_{4}$. This procedure was described earlier. The halogenation step is carried out at room temperature in $\mathrm{CH}_{2} \mathrm{Cl}_{2}$ using about $10 \mathrm{mg}$ of either $\mathrm{PH}_{3} \mathrm{PBr}_{2}$ or $\mathrm{PH}_{3} \mathrm{PI}_{2}$. Conversions of the alcohol to the bromide are near quantitative for 2 minutes of reaction, and somewhat less to convert to the iodide.

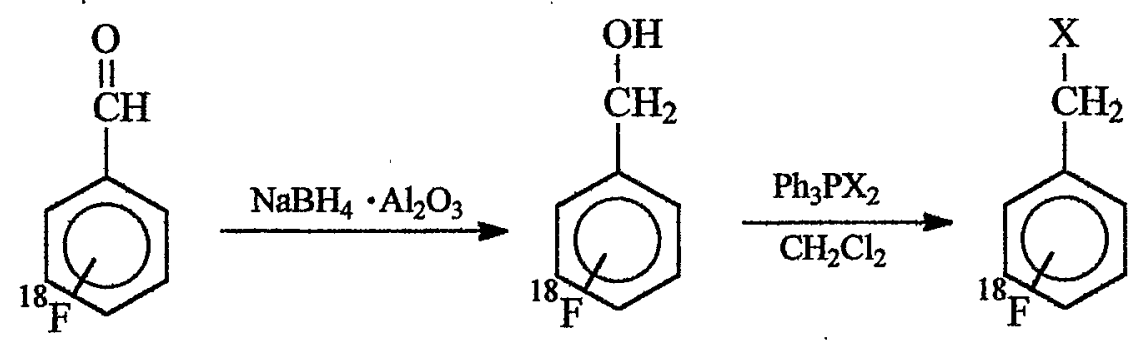


iii. Preparation of $\left[^{18} F\right]$ fluoroalkylbenzylsulfonate esters:

An extension of the $\left[{ }^{18} \mathrm{~F}\right]$ benzylating agents includes the small group of $\left[{ }^{18} \mathrm{~F}\right]$ fluoroalkylbenzylsulfonate esters which provide a way to attach radiofluorinated aromatic groups with longer carbon side-chains. (Choe et al., 1998) The method for making these precursors involves $\left[{ }^{18} \mathrm{~F}\right]$ fluoride displacement of the corresponding bisulfonate ester. The incorporation of $\left[{ }^{18} \mathrm{~F}\right]$ fluoride into 1,4-benzenedimethanol bimesylate or bitosylate is somewhat low (on average 32\%), but acceptable for subsequent radiolabeling. In application, the $\left[{ }^{18} \mathrm{~F}\right]$ fluoromethylbenzylsulfonate ester was prepared and reacted with spiperone and 1-phenylpiperizine to yield 3-N-(4$\left[{ }^{18} \mathrm{~F}\right]$ fluoromethylbenzyl)spiperone and $1-\mathrm{N}-\left(4-\left[{ }^{18} \mathrm{~F}\right]\right.$ fluoromethylbenzyl)-4phenylpiperazine as products demonstrating the precuror's efficacy for radiolabeling amides and secondary amines.
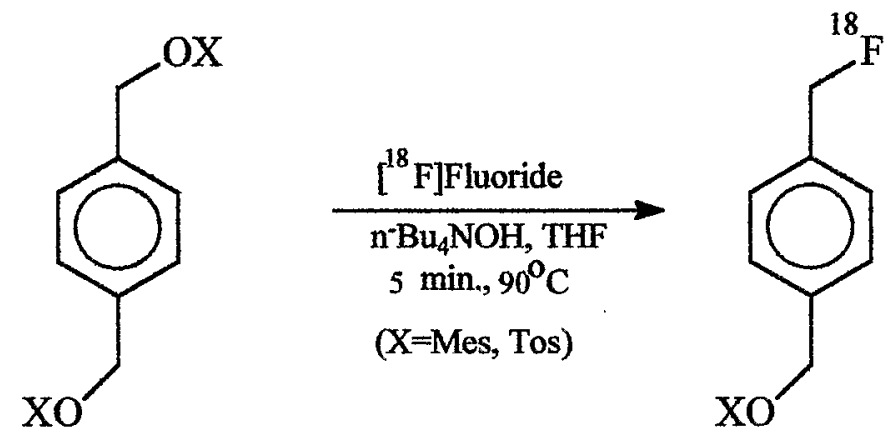

iv. Preparation of $\left[{ }^{18}\right.$ F]fluorohalobenzenes:

${ }^{18}$ F]Fluorohalobenzenes are useful precursors in the synthesis of a variety of fluorine-18 labeled aryl-lithium, aryl-magnesium and aryl-zinc compounds, which can be used to form carbon-carbon bonds through their reaction with suitable electrophilic reagents. A number of methods exist for producing this class of precursor although only two are acceptable for radiofluorination of receptor-based imaging agents.

The first reported method involved recoil labeling of halobenzenes using a target comprised of an appropriate halobenzene mixed with hexafluorobenzene. (Berei $e t$ al., 1974; Berei et al., 1987) Fluorine-18 was produced using the ${ }^{19} \mathrm{~F}(\mathrm{n}, 2 \mathrm{n}){ }^{18} \mathrm{~F}$ nuclear reaction. As is typical with this approach, radiochemical yields of the $\left[{ }^{18} \mathrm{~F}\right]$ fluorohalobenzene are $<1 \%$ with low specific activity.

A second approach relies on electrophilic fluorination using $\left[{ }^{18} \mathrm{~F}\right] \mathrm{F}_{2}$ or $\left[{ }^{18} \mathrm{~F}\right]$ acetyl hypofluorite on para-substituted phenyl derivatives of tin or other suitable metal. (Coenen et al., 1987) While radiochemical yields are typically in excess of $60 \%$, specific activity of the final product is usually unsuitable to make this approach practical.

A third approach involves nucleophilic substitution of no-carrier-added $\left[{ }^{18} \mathrm{~F}\right]$ fluoride producing $4-\left[{ }^{18} \mathrm{~F}\right]$ fluorochlorobenzene in a $14 \%$ yield after a rather long (85 minute), and complicated three-step synthesis. (Feliu, 1988) The process involves $\left[{ }^{18} \mathrm{~F}\right]$ fluoride exchange on 1,4-dinitrobenzene followed by reduction and diazotation to yield $\left[{ }^{18} \mathrm{~F}\right]-p$-fluorobenzene-diazonium chloride. The key reaction in this three-step synthesis is the reduction of the diazonium chloride using sodium cyanoborohydride.

The final approach is very attractive because it requires only a single step involving direct nucleophilic aromatic substitution of $\left[{ }^{18} \mathrm{~F}\right]$ fluoride on appropriate 
halophenyl-trimethylammonium salts. The method was applied to the preparation of 4$\left[{ }^{18}\right.$ F]fluorobromobenzene and $4-\left[{ }^{18} \mathrm{~F}\right]$ fluoroiodobenzene in relatively high yield $(50 \%)$.
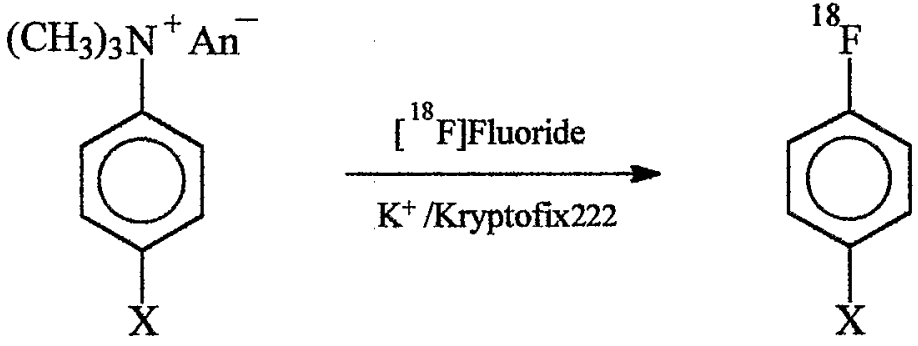

$(\mathrm{X}=\mathrm{Br}, \mathrm{I}) \quad\left(\mathrm{An}=\mathrm{TfO}^{-}, \mathrm{I}^{-}, \mathrm{Tos}^{-}, \mathrm{MeOSO}_{2} \mathrm{O}^{-}\right)$

\section{v. Preparation of $\left[{ }^{18}\right.$ Flfluoroarylketones:}

Attempts to expand the scope of radiofluorinations of large biologically active molecules resulted in the development of $p-\left[{ }^{18} \mathrm{~F}\right]$ fluorophenacyl bromide as a radiofluorinating agent. (Kilbourn et al., 1987; Downer et al., 1997) In additon to providing a means to radiofluorinate amine sites of large molecule, $p-\left[{ }^{18} \mathrm{~F}\right]$ fluorophenacyl bromide can be potentially useful for alkylating the thiol of free cysteine to form the corresponding thioether, or the methionine residues of proteins. (Glasel et al., 1966; Kanstrup et al., 1993)

$p-\left[{ }^{18} \mathrm{~F}\right]$ Fluorophenacyl bromide can be prepared by two methods both relying on the intermediate synthesis of $p-\left[{ }^{18} \mathrm{~F}\right]$ fluoroacetophenone. (Dence et $a l ., 1993$ ) The $p$ $\left[{ }^{18} \mathrm{~F}\right]$ fluoroacetophenone is prepared by nucleophilic substitution of $\left[{ }^{18} \mathrm{~F}\right]$ fluoride ion for the nitro group on $p$-nitroacetophenone. Typically, 55-60\% radiochemical yields are obtained in 5 minutes of reaction using microwave heating of a sealed $5 \mathrm{~mL}$ Reactivialm containing $2 \mathrm{mg}$ of substrate dissolved in DMSO. (Hwang et al., 1987) After reaction, the $p-\left[{ }^{18}\right.$ F $]$ fluoroacetophenone is purified using a C-18 Sep Pak. The first method for converting the radiolabeled acetophenone to $p-\left[{ }^{18} \mathrm{~F}\right]$ fluorophenacyl bromide involves dissolving the intermdiate in THF containing a small amount $(600 \mathrm{mg})$ of Perbromide on Amberlyst ${ }^{\mathrm{TM}} \mathrm{A}-26$ resin. After 10 minutes of reaction at $60^{\circ} \mathrm{C}$, the mixture can be easily extracted with dilute thiosulfate solution, and purified by Sep-Pak to generate $65 \%$ yield of the radiofluorinating precursor.<smiles>CC(=O)c1ccc([N+](=O)[O-])cc1</smiles><smiles>CC(=O)c1ccc([18F])cc1</smiles>

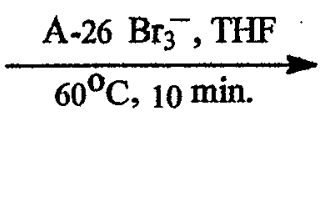<smiles>O=C(CBr)c1ccc(F)cc1</smiles>

In a second less efficient method, the radiolabeled acetophenone is mixed in glacial acetic acid treated with $10 \mathrm{mg}$ of 4-(dimethylamino)pyridiniumbromide perbromide and heated 
for 10 minutes at $90^{\circ} \mathrm{C}$. Final extraction generates about $42 \%$ of purified precursor, somewhat lower than the resin approach, but acceptable.

\section{Conclusions}

It is evident from this chapter that there is enormous flexibility both in the selection of the nature of the radioisotope and ways to generate it, as well as in the selection of the labeling precursor to appropriately attach that radioisotope to some larger biomolecule of interest. The arsenal of radiolabeling precursors now available to the chemist is quite extensive, and without a doubt will continue to grow as chemists develop new ones. However, the upcoming years will perhaps reflect a greater effort in refining existing methods for preparing some of those precursors that are already available to us. For example, the use of solid-phase reactions to accomplish in a single step what would normally take several using conventional solvent-based reactions has already been shown to work in many occasions. The obvious advantage here is that processes become more amenable to system automation thus affording greater reliability in day-to-day operations. There are perhaps other technologies in science that have yet to be realized by the chemist in the PET laboratory that could provide a similar or even a greater benefit. One only needs to be open to new ideas, and imaginative enough to apply them to the problems at hand.

Acknowledgements: This research was carried out at Brookhaven National Laboratory under contract DE-AC02-98CH10886 and with the U.S. Department of Energy and supported by its Office of Biological and Environmental Research, and also by the National Institutes of Health (National Institute on Drug Abuse and National Institutes of Neurological Diseases and Stroke).

\section{Referernces}

Aamodt RL, Peterson V and Phillips R (1952) ${ }^{12} \mathrm{C}(\mathrm{p}, \mathrm{pn}){ }^{11} \mathrm{C}$ cross section from threshold to $340 \mathrm{MeV}$. Phys. Rev., 88, 739-742.

AlexoffD, Schlyer DJ and Wolf AP (1989) Recovery of $\left[{ }^{18} \mathrm{~F}\right]$ fluoride from $\left[{ }^{18} \mathrm{O}\right]$ water in an electrochemical cell. Appl. Radiat. Isot. 40, 1-4.

Andersson $Y$ and Långström B (1994) Transition-mediated reactions using $\left[{ }^{11} \mathrm{C}\right]$ cyanide in synthesis of "C-labeled aromatic compounds. $J$. Chem. Soc., Perkin Trans., 1, 13951400.

Angelini G, Speranza M., Wolf AP and Shiue C -Y (1985) Nucleophilic aromatic substitution of activated cationic groups by ${ }^{18} \mathrm{~F}$-labeled fluoride. A useful route to nocarrier-added ${ }^{18}$ F-labeled aryl fluorides. J. Fluorine Chem. 27, 177-187.

Antoni G, Malmborg $\mathrm{P}$ and Långström B (1989) Synthesis of ${ }^{11} \mathrm{C}$-labeled halonitriles and examples of their use in alkylation reactions. Ann. Univ. Turkuensis, D27, Proceedings from the $5^{\text {th }}$ Symposium on the Medical Applications of Cyclotrons, Turku Finland. 
Antoni G, Malmborg P, Långström B (1991) Synthesis of [CN- ${ }^{11}$ C]acrylonitrile. J. Label Cmpds. Radiopharm. 30, 148,Proceedings of the $8^{\text {th }}$ Int. Symposium on Radiopharmaceutical Chemistry, Princeton, USA.

Attina M, Cacace F and Wolf AP (1983) Displacement of a nitro group by $\left[{ }^{18} \mathrm{~F}\right]$ fluoride ion. A new route to aryl fluorides of high specific activity. J. Chem. Soc., Chem Commun. 108.

Backhausen H, Stöcklin $\mathrm{G}$ and Weinreich R (1981) Formation of ${ }^{18} \mathrm{~F}$ via its ${ }^{18} \mathrm{Ne}$ precursor. Radiochim. Acta., 29, 1-5.

Balatoni J, Adam M and Hall L (1989) Synthesis of ${ }^{11}$ C-labeled aromatics using aryl chromium tricarbonyl intermediates. J. Label. Cmpd. Radiopharm. 27, 1429-1435.

Barrio JR, Satymurthy N, Ku H and, Phelps ME (1983) The acid decomposition of 1aryl-3,3-diakyl-triazenes. Mechanistic changes as a function of aromatic subtitution, nucleophilic strength and solvent. J. Chem. Soc. Chem. Commun., 443-444.

Berei K, Vasaros L, Noreeyev YV and Sutyor J (1987) Substitution effects in hot replacement by recoil halogens. Radiochim. Acta. 42, 13-20.

Berei $\mathrm{K}$ and Vasaros L (1974) Reactions of recoil fluorine in liquid halobenzenes. Radiochim Act., 21, 75-82.

Berger G, Maziere M, Prenant C, and Comar D (1980) Synthesis of carbon-11 labeled acetone. J. Appl. Radiat. Isot., 31, 577-578.

Bergman J and Solin O (1997) Fluorine-18-labeled fluorine gas for synthesis of tracer molecules. Nucl. Med. \& Biol., 24, 677-683.

Berridge MS, Crouzel C and Comar D (1985) Aromatic fluorination with NCA F-18 fluoride: a comparative study. J. Label. Cmpds Radiopharm. 22, 687-690.

Berridge MS and Tewson TJ (1986) Chemistry of ${ }^{18} \mathrm{~F}$ radiopharmaceutical. Appl. Radiat. Isot., 37, 685-694.

Berridge MS, Cassidy EH, Terris AH and Vesselle JM (1992) Preparation and in vivo binding of $\left[{ }^{11} \mathrm{C}\right]$ carazolol, a radiotracer for the beta-adrenergic receptor. Nucl. Med. Biol. 19, 563-569.

Berridge MS, Cassidy EH and Bordeaux KG (1994) Preparation of $\left[{ }^{11} \mathrm{C}\right]$ triamcinolone acetonide. Appl. Radiat. Isot. 45, 91-95. 1994.

Blessing G, Coenen HH, Franken K and Qaim SM (1986) Production of $\left[{ }^{18} \mathrm{~F}\right] \mathrm{F}_{2}, \mathrm{H}^{18} \mathrm{~F}$ and ${ }^{18} \mathrm{~F}_{\mathrm{aq}}$ using the ${ }^{20} \mathrm{Ne}(\mathrm{d}, \alpha){ }^{18} \mathrm{~F}$ process. Appl. Radiat. Isot., 37, 1135-1140. 
Block D, Klatte B, Knochel A, Beckman R and Holm U. (1986) NCA [ ${ }^{18}$ F]-labeling of aliphatic compounds in high yields via aminopolyether supported nucleophilic substitution. J. Label. Cmpds. Radiopharm. 23, 467-477.

Block D, Coenen HH and Stöcklin G (1987) The NCA nucleophilic ${ }^{18} \mathrm{~F}$-fluorination of 1$\mathrm{N}$-disubstituted alkanes as fluoroalkylating agents. J. Label. Cmpds. Radiopharm., 24(9), 1029-1042.

Block D, Coenen HH and Stöcklin G (1988a) NCA ${ }^{18} \mathrm{~F}$-Fluoroalkylation of $\mathrm{H}$-acidic compounds. J. Label. Cmpds. Radiopharm. 25(2), 201-216.

Block D, Coenen HH and Stöcklin G (1988b) NCA ${ }^{18} \mathrm{~F}$-fluoroacylation via fluorocarboxylic acid esters. J. Label. Cmpds. Radiopharm. 25(2), 185-200.

Brill OD (1965) ${ }^{3} \mathrm{He}-\mathrm{Light}$ nucleus interaction cross sections. Soviet J., Nucl. Phys., 1, $37-42$.

Brill OD, Sumin LV (1960) Nuclear cross sections on beryllium targets. Soviet $J$. At. Energy, 7, 856-860.

Brinkman GA, Hass-Lisewska I, Veenboer J T and Lindner L (1978) Preparation of ${ }^{11} \mathrm{COCl}_{2}$. Int. J. Appl. Radiat. Isotopes, 29, 701-703.

Brodack JW, Kilbourn MR, Welch MJ and Katzenellenbogen JA (1986) NCA 16- $\alpha$ $\left[{ }^{18}\right.$ F]fluoroestradiol-17- $\beta$ : the effect of reaction vessel on fluorine-18 resolubilization, product yield and effective specific activity. Appl. Radiat. Isot., 37, 217-221.

Buckingham PD and Forse GR (1963) The preparation and processing of radioactive gases for clinical use. Int. J. Appl. Radiat. Isot.14, 439-451.

Bustany P, Henry JF, Soussaline F and Comar D (1983) Brain protein synthesis in normal and demented patients: A study by positron emission tomogaphy with ${ }^{11} \mathrm{C}-\mathrm{L}$ methionine. in Functional Radionuclide Imaging of the Brain, Magistretti P.L., (ed.) Raven Press, New York, p. 319-328.

Cacace F, Giacomello G and Zifferero M (1958) Ions acceleration for labeling chemical compounds. Energia Nucleare, 5, 287-293.

Casella V, Ido T, Wolf AP, Fowler JS, MacGregor RR and Ruth TJ (1980) Anhydrous ${ }^{18} \mathrm{~F}$ labeled elemental fluorine for radiopharmacutical production. J. Nucl. Med., 21, 750 757.

Chakraborty P K and Kilbourne MR (1991) Oxidation of substituted 4fluorobenzaldehydes: application to the no-carrier-added syntheses of 4$\left[{ }^{18} \mathrm{~F}\right]$ fluoroguaiacol and 4-[ $\left.{ }^{18} \mathrm{~F}\right]$ fluorocatechol. Appl. Radiat. Isot. 42(7), 673-681.

Chesis PL and Welch MJ (1990) Comparison of bromo- and iodoalkyl triflates for ${ }^{18} \mathrm{~F}$ radiolabeling of amines. Appl. Radiat. Isot., 41(3), 259-265. 
Chirakal, R, Firnau G, Schrobilgen GJ, McKay J and Garnett ES (1984) The synthesis of $\left[{ }^{18} \mathrm{~F}\right]$ xenon difluoride from $\left[{ }^{18} \mathrm{~F}\right]$ fluorine gas. Int. J. Appl. Radiat. Isot., 35(5), 401-404.

Chirakal R, Firnau G and Garnett ES (1988) Sequential production of electrophilic and nucleophilic fluorinating agents from $\left[{ }^{18} \mathrm{~F}\right]$ fluorine gas. Appl. Radiat. Isot,. $39(10)$, 1099. 1101.

Choe YS, Song DH, Lee K-J, Kim SE, Choi Y, Lee KH, Kim B-T, Oh SJ and Chi DY (1998) $\left[{ }^{18}\right.$ F]Fluoromethylbenzylsulfonate ester: a rapid and efficient synthetic method for the $\mathrm{N}-\left[{ }^{18} \mathrm{~F}\right]$ fluoromethylbenzylation of amides and amines. Appl. Radiat. Isot., 49(1-2), 73-77.

Christman DR, Hoyte RM and Wolf AP (1970) Organic radiopharmaceuticals labeled with isotopes of short half-life I: ${ }^{11} \mathrm{C}$-dopamine hydrochloride. J. Nucl. Med. 11, 474476.

Christman DR, Crawford EJ, Friedkin M and Wolf AP (1972) Detection of DNA synthesis in intact organisms with positron-emitting (methyl- ${ }^{11} \mathrm{C}$ )thymidine. Proc. Natl. Acad. Sci., 69, 988-992.

Christman DR, Finn RD Kalstrom KI, and Wolf AP (1975) The production of ultra high specific activity ${ }^{11} \mathrm{C}$-labelled hydrogen cyanide, carbon dioxide, carbon monoxide and methane via the ${ }^{14} \mathrm{~N}(\mathrm{p}, \alpha)^{11} \mathrm{C}$ reaction. Int. J. Appl. Radiat. Isot., 26, 435-441.

Christman DR, Finn RD and Wolf AP (1979) A novel synthesis of carbon-11 labeled phosgene. Proceedings $10^{\text {th }}$ Hot Atom Chem. Symp., Loughborough, 41 .

Clark JG and Silvester DJ (1966) A cyclotron method for the production of fluorine-18. Int. J. Appl. Radiat. Isotopes, 17, 151-156.

Clark IC and Buckingham PD (1971) The preparation and storage of radioactive carbon11 gases for clinical use. Int. J. Appl. Radiat. Isot., 22, 639-645.

Clark J and Buckingham P (1975) Short-Lived Radioactive Gases for Clinical Use. Butterworths, London.

Clark JC and Oberdorfer F (1982) Thermal characteristics of the release of fluorine-18 from an Inconel-600 gas target. $J$. Labeled Cmpd. Radiopharm. 19, 1337-1339.

Coenen HH, Klatte B, Knochel A, Schuller M and Stöcklin G (1986a) Preparation of NCA $\left[17-{ }^{18}\right.$ F] fluoroheptadecanoic acid in high yields via aminopolyether supported nucleophilic substitution. J. Label. Cmpds. Radiopharm., 23, 455-466.

Coenen HH, Colosimo M, Shuller M and Stöcklin G (1986b) Preparation of NCA $\left[{ }^{18} \mathrm{~F}\right] \mathrm{CH}_{2} \mathrm{BrF}$ via aminopolyether supported nucleophilic substitution. J. Label. Cmpds. Radiopharm. $23(6), 587-595$. 
Coenen HH and Moerlein SM (1987) Regiospecific aromatic fluorometallation of group IVb metalloarenes using elemental fluorine or acetyl hypofluorite. J. Fluor. Chem., 36, 63-70.

Coenen HH (1989) No-carrier-added ${ }^{18} \mathrm{~F}$ chemistry of radiopharmaceuticals. in Synthesis and Applications of Isotopically Labeled Compounds (Eds. Baillie TA and Jones JR, Elsevier, Amsterdam, 443-448.

Constantinou M, Aigbirhio FI, Smith RG, Ramsden CA and Pike VW (2001) Xenon difluoride exchanges fluoride under mild conditions: a simple preparation of $\left[{ }^{18} \mathrm{~F}\right] \mathrm{xenon}$ difluoride for PET and mechanistic studies. J. Am. Chem. Soc., 123, 1780-1781.

Cramer RD and Kistiokosky GB (1941) The synthesis of radioactive lactic acid. J. Biol. Chem., 137, 549-552.

Crane HR and Lauritsen CC (1934) Further experiments with artificially produced radioactive substances. Phys. Rev., 45, 497-502.

Crouzel C and Comar D (1978) Production of carrier-free ${ }^{18} \mathrm{~F}$-hydrofluoric acid. Int. J. Appl. Radiat. Isot., 29, 407-410.

Crouzel C, Sejourne C, Comar D (1979) Production of " $\mathrm{C}$-acetylene by methane pyrolysis. J. Appl. Radiat. Isot., 30, 566-569

Damhaut P Cantineau R, Lemaire C, Plenevaux A, Christiaens L and Guillaume M (1991) 4- $\left[{ }^{18}\right.$ F]Fluorotropapride, a specific $\mathrm{D}_{2}$ receptor ligand for PET. J. Nucl. Med., 32, 935-942.

Damhauat P, Cantineau R, Lemaire C, Pleneveaux A, Christiaens L and Guillaume M (1992) 2- and 4-[ $\left.{ }^{18} F\right]$ Fluorotropapride, two specific $D_{2}$ receptor ligands for positron emission tomography: NCA syntheses and animal studies. Appl. Radiat. Isot. 43, 12651274.

Dannals RF, Ravert HT, Wilson AA and Wagner HN (1991) Special problems associated with the synthesis of high specific activity carbon-11 labeled radiotracers," in New Trends in Radiopharmaceutical Synthesis, Quality Assurance, and Regulatory Control, Emran A.M. (ed.) Plenum Press, New York 21-30.

De Kleijn JP (1977) Organic synthesis with fluorine-18; a concise survey. J. Fluorine Chem., 10, 5341-5349.

Dence CS, McCarthy TJ and Welch MJ (1993) Improved synthesis of $p$ $\left[{ }^{18} \mathrm{~F}\right]$ fluorophenacyl bromide: the use of polymer supported perbromide. Appl. Radiat. Isot., 44, 981-983.

Dence CS, John CS, Bowen WD and Welch MJ (1997) Synthesis and evaluation of $\left[{ }^{18}\right.$ F]labeled benzamides: high affinity sigma receptor ligands for PET imaging. Nucl. Med. Biol. 24, 333-340. 
Ding Y -S, Shiue C -Y, Fowler JS, Wolf AP and Plenevaux A (1990) No-carrier-added (NCA) aryl $\left[{ }^{18} \mathrm{~F}\right]$ fluorides via the nucleophilic aromatic substitution of electron-rich aromatic rings. J Fluorine Chem. 48, 189-206.

Ding Y -S, Fowler JS, Gatley SJ, Dewey SL and Wolf AP (1991) Synthesis of high specific activity $(+)$ and $(-)-6-\left[{ }^{18}\right.$ F]fluoronorepinephrine via the nucleophilic aromatic substitution reaction. $J$. Med. Chem., 34, 767-775.

Downer JB, McCarthy TJ, Edwards WB, Anderson CJ and Welch MJ (1997) Reactivity of $p-\left[{ }^{18} \mathrm{~F}\right]$ fluorophenylacyl bromide for radiolabeling of proteins and peptides. $A p p l$. Radiat. Isot. 48(7), 907-916.

Efange SMN, Mach RH, Khare A, Michelson RH, Nowak PA and Evora PH (1994) p$\left[{ }^{18} \mathrm{~F}\right]$ Fluorobenzyltrozamicol $\left.\left({ }^{18} \mathrm{~F}\right] \mathrm{FBT}\right)$ : molecular decomposition-reconstitution approach to versamicol receptor radioligands for positron emission tomography. Appl. Radiat. Isot., 45, 465-472.

Ehrenkaufer RE and MacGregor RR (1983a) Synthesis of $\left[{ }^{18} \mathrm{~F}\right]$ perchloro fluoride and its reactions with functionalized aryl lithiums. Int. J. Appl. Radiat. Isot., 34(3), 613-615.

Ehrenkaufer RE, MacGregor RR, Wolf AP, Fowler JS, Ruth TJ, Schlyer DJ and Wieland $\mathrm{BN}$ (1983b) Production of $\mathrm{H}^{18} \mathrm{~F}$ by deuteron irradiation of a neon-hydrogen gas target. Radiochim. Acta. 33, 49-56.

Elsinga PH, Keller E, De Groot T J, Visser GM and Vaalburg W (1995) Synthesis of $\left[{ }^{11} \mathrm{C}\right]$ methyl magnesium iodide and its application to the introduction of $\left[{ }^{11} \mathrm{C}\right]-\mathrm{N}$-tertbutyl groups and $\left.{ }^{11} \mathrm{C}\right]$-sec-alcohols. Appl. Radiat. Isot., 46(4), 227-231.

Emran AM, Boothe TE and Finn RD (1985) Optimized production of high specific activity [ ${ }^{11}$ C]urea. Intl. J. Appl. Radiat. Isot., 36, 739-742.

Epherre EM and Seide C (1971) Excitation functions of ${ }^{7} \mathrm{Be}$ and ${ }^{11} \mathrm{C}$ produced in nitrogen by low-energy protons. Phys. Rev., C3, 2167-2171.

Feliu AL (1988) Synthetic studies with $\left[{ }^{18} \mathrm{~F}\right]-p$-fluorobenzenediazonium chloride: application to the synthesis of a radiolabeled glucocorticoid, $\left[{ }^{18}\right.$ F]WIN 44577 . J. Label. Cmpds. Radiopharm., 25(11), 1245-1254.

Ferrieri RA, MacGregor RR, Rosenthal S, Schlyer DJ, Fowler JS and Wolf AP (1982) A $\mathrm{CF}_{4}-\mathrm{H}_{2}-\mathrm{Ne}$ gas target for reproducible high yields of anhydrous $\mathrm{H}^{18} \mathrm{~F}$. J. Label. Cmpds. Radiopharm. 19, 1620-1622.

Ferrieri RA and Wolf AP (1983a) The chemistry of positron emitting nucleogenic (hot) atoms with regard to preparation of labeled compounds of practical utility. Radiochimica Acta., 34, 69-83. 
Ferrieri RA, Schlyer DJ, Wieland BW, Wolf AP (1983b) On-line production of ${ }^{13} \mathrm{~N}$ nitrogen gas from solid enriched ${ }^{13} \mathrm{C}$-target, and its application to ${ }^{13} \mathrm{~N}$-ammonia synthesis using microwave radiation. J. Appl. Radiat. Isot., 34(6),897-890.

Finn RD, Christman DR, Ache HJ and Wolf AP (1971) The preparation of cyanide- ${ }^{11} \mathrm{C}$ for use in the synthesis of organic radiophaarmaceuticals. Int. J. Appl. Radiat. Isot., 22, $735-740$.

Finn RD, Boothe TE, Vora MM, Hildner JC, Emran AM and, Kothari PJ (1984) Syntheses with isotopically labeled carbon: methyl iodide, formaldehyde and cyanide. Int. J. Appl. Radiat. Isot. 35, 323-335.

Firnau G, Chirakal R, Sood S and Garnett ES (1980) Aromatic fluorination with xenon difluoride: L-3,4-dihydroxy-6-fluoro-phenylalanine. Can. J. Chem., 58, 1449-1453.

Firouzbakht ML, Schlyer DJ and Fowler JS (1999a) Irradiation of ammonia at liquid nitrogen temperatures: the mechanistic implications for direct production of $\left[{ }^{11} \mathrm{C}\right] \mathrm{HCN}$. Abstract in $8^{\text {th }}$ Workshop on Targetry and Target Chemistry, St. Louis, Missouri.

Firouzbakht ML, Schlyer DJ and Fowler JS (1999b) Cryogenic target design considerations for the production of $\left[{ }^{18} \mathrm{~F}\right]$ fluoride from enriched $\left[{ }^{18} \mathrm{O}\right]$ carbon dioxide. Nucl. Med. \& Biol., 26, 749-753.

Fitschen J, Beckmann R, Holm U and Neuert $\mathrm{H}$ (1977) Yield and production of ${ }^{18} \mathrm{~F}$ by ${ }^{3}$ He irradiation of water. Int. J., Appl. Radiat. Isotopes, 28, 781-784.

Fowler JS and Wolf AP (1986) Positron emitter-labeled compounds: priorities and problems in positron emission tomography and autoradiography: principles and applications for the brain and heart. In Positron Computed Tomography, Phelps ME, Mazziotta PM, Schelbert H, (eds.), Raven Press, New York, 391-450.

Fowler JS and Wolf AP (1982) The synthesis of carbon-11, fluorine-18 and nitrogen-13 labeled radiotracers for biomedical applications. NAS-NS-3201, National Academy of Science, National Research Council, National Technical Information Service.

Fowler JS and Wolf AP (1997) Working against time: rapid radiotracer synthesis and imaging of the human brain. Acc. Chem. Res., 30, 181-188.

Garg PK, Garg S and Zalutsky MR (1991) fluorine-18 labeling of monoclonal antibodies and fragments with preservation of immunoreactivity. Bioconj. Chem. 2, 44-52.

Gatley SJ and Shaughnessy WJ (1981) Nucleophilic substitution with fluoride: effects of solvent, temperature, ions, leaving group, and water. J. Label. Cmpds. Radiopharm., 19, 24-25.

Gatley SJ, Kornguth M, DeGrado TRand Holden JE (1986) Kinetic studies with ${ }^{18} \mathrm{~F}$ fluoride. J. Label. Cmpds. Radiopharm.,23, 1199-1201. 
Gatley SJ (1989) Rapid production and trapping of $\left[{ }^{18} \mathrm{~F}\right]$ fluorotrimethylsilane, and its use in nucleophilic fluorine-18 labeling without an aqueous evaporation step. Appl. Radiat. Isot. 40(6), 541-544.

Glasel JA, Vratsanos SM, Wasserman N and Erlanger BF (1966) Cyclization of S-(pbromophenacyl)-L-cysteine as observed by nuclear resonance spectroscopy. Archs. Biochem. Biophys. 115, 237-246.

Grierson JR, Biskupiak JE, Link JM and Krohn KA (1993) Radiosynthesis of 6- $\left[{ }^{11} \mathrm{C}\right]-\mathrm{D}-$ glucose. Appl. Radiat. Isot., 44(9), 1449-1454.

Guhlke S, Coenen HH and Stöcklin G (1994) Fluoracylation agents based on small nca $\left[{ }^{18} \mathrm{~F}\right]$ fluorocarboxylic acids. Appl. Radiat. Isot., 45(6), 715-727.

Hahn RL and Ricci E (1966) Interaction of ${ }^{3} \mathrm{He}$ particles with ${ }^{9} \mathrm{Be}{ }^{12} \mathrm{C},{ }^{16} \mathrm{O}$ and ${ }^{19} \mathrm{~F}$. Phys. Rev., 146, 650-655.

Halldin C and Långström B (1984) Synthesis of [ ${ }^{11}$ C]labeled aldehydes. Acta. Chem. Scand., B 38, 1-4. .

Halldin C, Högberg T and Farde L (1994) Fluorine-18 labeled NCQ 115, a selective dopamine $\mathrm{D}_{2}$ receptor ligand. Preparation and positron emission tomography. Nucl. Med. Biol. 21, 627-631.

Hamacher K, Coenen HH and Stöcklin G (1986a) Stereospecific synthesis of NCA 2$\left[{ }^{18} \mathrm{~F}\right]$ fluoro-2-deoxy-D-mannose and 2-[ $\left[{ }^{18} \mathrm{~F}\right]$ fluoro-2-deoxy-D-glucose and the influence of added carrier (KF) on FDG synthesis. J. Label. Cmpd. Radiopharm., 23(8), 10951098 .

Hamacher K, Coenen HH and Stöcklin G (1986b) Efficient stereospecific synthesis of NCA 2- $\left[{ }^{18}\right.$ F]fluoro-2-deoxy-D-glucose using aminopolyether supported nucleophilic substitution. J. Nucl. Med., 27, 235-238.

Hamacher K, Coenen HH and Stöcklin G (1986c) NCA Radiofluorination of spiperone and N-methylspiperone via aminopolyether supported direct nucleophilic substitution. $J$. Label. Cmpds. Radiopharm., 23(8), 1047-1051.

Hamacher K, Blessing G and Nebeling B ( 1990) Computer-aided synthesis of no-carrieradded $\left[{ }^{18} \mathrm{~F}\right] \mathrm{FDG}$ using aminopolyether supported nucleophilic fluorination. Appl. Radiat. Isot., 41, 49-53.

Hatano K, Ido T and Iwata R (1991) The synthesis of $o$ - and $p-\left[{ }^{18} \mathrm{~F}\right]$ fluorobenzyl bromides and their application to the preparation of labeled neuroleptics. J. Label. Cmpds. Radiopharm. 24(4), 373-380.

Hebel D, Kirk KL, Cohen LA and Labroo VM (1990) First direct fluorination of tyrosine-containing biologically active peptides. Tetrahedron Lett. 31, 619-620. 
Helus F, Wolber G, Sahm U, Abrams D and Mier-Borst W (1979) ${ }^{18}$ F Production methods. J. Label. Cmpd. Radiopharm., 16, 214-217.

Hintz NM and Ramsey NF (1952) Excitation functions to $100 \mathrm{MeV}$. Phys. Rev., 88, 1924

Hwang D -R, Moerlein SM, Lang L and Welch MJ (1987) Application of microwave technology to the synthesis of short-lived radiopharmaceuticals. J. Chem. Soc., Chem. Commun. 1799-1780.

Hwang D -R, Dence CS, McKinnon SA, Mathia CJ and Welch MJ (1991) Positron labeled muscarinic acetylcholine receptor antagonist: 2 - and $4-\left[{ }^{18} \mathrm{~F}\right]$ fluorodexetimide. Synthesis and biodistribution. Nucl. Med. Biol., 18, 247-252.

Hylten $\mathrm{G}$ (1970) An investigation of the ${ }^{12} \mathrm{C}(\gamma, \mathrm{n})^{11} \mathrm{C}$ reaction for the $\mathrm{E} \gamma$ up to $1 \mathrm{GeV}$. Nucl. Phys., A158, 225-231.

Irie T, Fukushi F, Ido T, Nazaki T and Kasida $\mathrm{Y}(1982){ }^{18} \mathrm{~F}$-Fluorination by crown ethermetal fluoride: labeling [ $\left.{ }^{18} \mathrm{~F}\right]-2$-fluoroprogesterone. Int. J. Appl. Radiat. Isot., 33, 14491452.

Irie T, Fukushi F, Ido T, Nazaki T and Kasida $\mathrm{Y}(1984){ }^{18} \mathrm{~F}$-Fluorination by crown ethermetal fluoride: no-carrier-added labeling method. Int. J. Appl. Radiat. Isot., 35, 517-520.

Ishiwata $\mathrm{K}$, Noguchi J, Ishi $\mathrm{S}$, Hatano $\mathrm{K}$, Ito $\mathrm{K}$, Nabeshima $\mathrm{T}$ and Senda $\mathrm{M}$, (1998) Synthesis and preliminary evaluation of $\left[{ }^{11} \mathrm{C}\right] \mathrm{NE}-100$ labeled in two different positions as a PET o-receptor ligand. Nucl. Med. Biol., 25(3), 195-202.

Ishiwata K, Ishi S-I, Shinoda M, Maekawa S and Senda M (1999) Automated synthesis of radiochemically pure ${ }^{11} \mathrm{C}$-labelled ethyl, propyl, and butyl iodides. Appl. Radiat. and Isot., 50, 693-697.

Iwata, R, Pascali C, Bogna A, Horvath G, Kovacs Z, Yanai K. and Ido T (2000) A new, convenient method for the preparation of $4-\left[{ }^{18} \mathrm{~F}\right]$ fluorobenzyl halides. Appl. Radiat. Isot. $52,87-92$.

Iwata R, Ido T and Saji H (1979) A remote controlled synthesis of ${ }^{11} \mathrm{C}$-iodomethane for the practical preparation of ${ }^{11} \mathrm{C}$-labeled radiopharmaceuticals. Int. J. Appl. Radiat. Isot., 30, 194-196.

Jewett DM, Potocki JF, and Ehrenkaufer RE (1984)A gas-solid-phase microchemical method for the synthesis of acetyl hypoffuorite. J. Fluorine Chem., 24, 477-481.

Jewett DM, Toorongian SA, Mulholland GK, Watkins GL and Kilbourn MR (1988) Multiphase extraction: rapid phase-transfer of $\left[{ }^{18} \mathrm{~F}\right]$ fluoride for nucleophilic radiolabelling reactions. Appl. Radiat. Isot., 39, 1109-1111. 
Jewett DM (1992) A simple synthesis of $\left[{ }^{11}\right.$ C]methyl triflate. Appl. Radiat. Isot., 43, 1383-1385.

Kaneko S, Ishiwata K, Ishii S-I, Omura H and Senda M(1999) Enzymatic synthesis of carbon-11 labeled methionine and its derivatives with immobilized $\gamma$-cyano- $\alpha-$ aminobutyric acid synthase. Appl. Radiat. Isotopes, 51, 285-291.

Kanstrup A, Breddam K and Buchardt O (1993) Application of quantitative structureactivity relationship modeling to the evaluation of the changes in enzymatic activity of carboxypeptidase $Y$ upon chemical modifications. Archs biochem. Biophys. 304, 332337.

Kiesewetter DO, Eckelman WC, Cohen RM, Finn RD and Larson SM (1986) Syntheses and $\mathrm{D}_{2}$ receptor affinities of derivatives of spiperone containing aliphatic halogens. Appl. Radiat. Isot., 37, 1181-1188.

Kihlberg T, Gullberg P and Långström B (1990) $\left[{ }^{11}\right.$ C]Methyltriphenylphosphine, a new precursor used in a one pot Wittig synthesis of $\left[\beta{ }^{11} \mathrm{C}\right]$ styrene. J. Label. Cmpd. Radiopharm. 28(10), 1115-1119.

Kilbourn MR, Saji $H$ and Welch MJ. (1982) $H^{18} F$ : Production and use in aromatic fluorinations via triazenes. In Nuclear Medicine and Biology I, Raynaud C. (ed.), Pergamon Press, Paris, 1101-1104.

Kilbourn MR, Dence CS, Welch MJ and Mathias CJ (1987) Fluorine-18 labeling of proteins. J. Nucl. Med. 28, 462-470.

Kilbourn MR (1990) Fluorine-18 labeling of Radiopharmaceuticals, in Nuclear Science Series, NAS-NS-3203, Nuclear Medicine, National Academy press, Washington D.C.

Kilbourn MR, Brodack JW, Chi DY, Dence CS, Jerabek PA, Katzenellenbogen JA, Patrick TB and Welch MJ (1986) ${ }^{18} \mathrm{~F}$-Fluoride ion: a versatile reagent for radiopharmaceutical syntheses. J. Label. Cmpds. Radiopharm., 23, 1174-1176.

Knust EJ, and Machulla H-J (1983) High yield production of ${ }^{18} \mathrm{~F}$ in a water target via ${ }^{16} \mathrm{O}\left({ }^{3} \mathrm{He}, \mathrm{p}\right){ }^{18} \mathrm{~F}$ reaction. Int. J. Appl. Radiat. Isot., 34, 1627-1630.

Koh W-J, Griffin TW, Rasey JS and Laramore GE (1994) Positron emission tomography. Acta. Oncologica, 33, 323-328.

Labar D and Van der Borght T (1991) Total synthesis of $2-\left[{ }^{11} \mathrm{C}\right]$ thymidine from [ ${ }^{11}$ C] $]$ rea: a tracer of choice for measurement of cellular proliferation using PET. J Label. Cmpd. Radiopharm., 30, 423-426.

Lamb JF, James RW and Winchell HS (1971) Recoil synthesis of high specific activity

${ }^{11}$ C-cyanide. Int. J. Appl. Radiat. Isot., 22, 435-437. 
Lang L and Eckelman WC (1994) One-step synthesis of ${ }^{18} \mathrm{~F}$ labeled $\left[{ }^{18} \mathrm{~F}\right]-\mathrm{N}$-succinimidyl 4-(fluoromethyl)benzoate for protein labeling. Appl. Radiat. Isot., 45(12),1155-1163.

Långström B and Lundqvist $\mathrm{H}$ (1976) The preparation of ${ }^{11} \mathrm{C}$-methyl iodide and its use in the synthesis of ${ }^{\mathrm{Il}} \mathrm{C}$-methyl-L-methionine. Int. J. Appl. Radiat. Isot., 27, 357-3663.

Långström $\mathrm{B}$, Antoni $\mathrm{G}$, Gullberg $\mathrm{P}$, Halldin $\mathrm{C}$, Nagren $\mathrm{K}$, Rimland $\mathrm{A}$ and Svard $\mathrm{H}$, (1986) Synthesis of $1-{ }^{11} \mathrm{C}$-alkyl iodides and examples of alkylation reactions. Appl. Radiat. Iso., 37, 1141-1144.

Långström B, Andersson Y, Antoni G, Axelsson S, Bjurling P Fasth K-J Gee A, Kihlberg $T$, Inoue $O$, Ulin J and Wantanabe $Y(1989 a)$ Molecular design and multitracer studies for mapping functions. Proceedings of Conference "Peace through Mind/Brain Science" in Hamamatsu, Japan, February 72-73.

Långström B, Antoni G, Andersson Y, Axelsson S, Bjurling P, Fasth K-J, Gee A, Hornfeldt K, Kihberg T, Westerberg G, Watanabe Y (1991) Aspects on the synthesis and design of ${ }^{11}$ C-tracers for PET, in New Trends in Radiopharmaceutical Synthesis, Quality Assurance, and Regulatory Control. Emran AM (ed.) Plenum Press, New York, 7-20.

Långström $\mathrm{B}$, Andersson $\mathrm{Y}$, Antoni G, Axelssoon S, Bjurling P, Fasth K-J, Gee A, Kihlberg T, Ulin J and Watanabe Y (1989b) Design of tracer molecules with emphasis on stereochemistry, position of label and multiple isotopic labeling. Acta. Radiologica., Proceedings of $5^{\text {th }}$ Symp.on the Medical Application of Cyclotrons, Turku, Finland, May, $44-45$.

Långström B, Andersson $Y$, Antoni G, Axelssoon S, Bjurling P, Fasth K-J, Gee A, Hornfeldt K, Kihlberg T., Ulin J, Westerberg G and Watanabe Y (1989c) Design and synthesis of tracers labeled with short-lived positron emitting radionuclides: carbon-11 and some applications. in Proceedings of the $19^{\text {th }}$ Japan Conference on Radiation and Isotopes, Tokyo, Japan, October, 121-122.

Larsen P, Ulin J, Dalhstrom K and Jensen M (1997) Synthesis of $\left[{ }^{11}\right.$ C]iodomethane by iodination of $\left[{ }^{11}\right.$ C]methane. Appl. Radiat. Isot, 48, 153-157.

Lemaire C, Guillaume M, Palmer AJ and Cantineau R (1987) A new route for the synthesis of $\left[{ }^{18} \mathrm{~F}\right]$ fluoroaromatic substituted amino acids: no carrier added L-p$\left[{ }^{18} \mathrm{~F}\right]$ fluorophenylalanine. Appl. Radiat. Isot., 38, 1033-1040.

Lemaire C, Guillaume M, Cantineau R and Christiaens L (1990) No-carrier-added regioselective preparation of 6-[ ${ }^{18}$ F]fluoro-L-dopa. J. Nucl. Med., 31, 1247-1251.

Lemaire C, Damhaut P, Plenevaux A, Cantineau R, Christiaens L and Guillaume M, (1991) Asymmetric synthesis of $4-\left[{ }^{18} \mathrm{~F}\right]$ fluoro-L-m-tyrosine via aromatic fluorination. $J$. Nucl. Med. 32, Abstract 112, 935. 
Lemaire C, Damhaut P, Plenevauz A, Cantineau R., Christiaens L and Guillaume M, (1992) Synthesis of fluorine-18 substituted aromatic aldehydes and benzyl bromides, new intermediates for nca $\left[{ }^{18}\right.$ F]fluorination. Appl. Radiat. Isot., 43(4), 485-494.

Lemaire C, Damhaut P, Plenevaux, A and Comar D(1994) Enantiomeric synthesis of 6[fluorine-18]-fluoro-L-dopa from no-carrier-added fluorine-18-fluoride. J. Nucl. Med., 35, 1996-2002.

Leskinen S, Lapela M., Lindholm P, Ann Minn H (1997) Metabolic imaging by positron emission tomography in oncology. Annals of Medicine, 29, 271-275.

Levy S, Elmaleh DR and Liuni E (1982) A new method using anhydrous $\left[{ }^{18} \mathrm{~F}\right]$ fluoride to radiolabel 2-[ ${ }^{18}$ F]fluoro-2-deoxy-D-glucose. J. Nucl. Med., 23, 918-922.

Lindner $\mathrm{M}$ and Osborne RN (1953) Energy dependence of the cross section for the reaction ${ }^{12} \mathrm{C}(\alpha, \alpha \mathrm{n}){ }^{11} \mathrm{C}$. Phys. Rev., 91, 1501-1505.

Link J, Grierson JR and Krohn KA (1995) Alternatives in the synthesis of 2$\left[{ }^{11} \mathrm{C}\right]$ thymidine. J. Label Cmpd. Radiopharm., 37, 610-612.

Link JM, Krohn KA and Clark JC (1997) Production of [ $\left.{ }^{11} \mathrm{C}\right] \mathrm{CHI}$ by single-pass reaction of $\left[{ }^{11} \mathrm{C}^{-} \mathrm{CH}_{4}\right.$ with $\mathrm{I}_{2}$. Nucl Med Biol. 24, 93-97.

Lintermans J, Erwin W and Lemmon RM (1972) Hot atom chemistry of carbon-14 in solid benzene at kinetic energies at or below 5 electron volts. $J$. Phys. Chem., 76(18), 2521-2524.

Loftfield RB(1947) Preparation of ${ }^{14} \mathrm{C}$-labeled hydrogen cynanide, alanine and glycine. Nucleonics, 1, 54-56.

Mach RH, Elder ST, Morton TE, Nowak PE, Evora PH, Scripko JG, Luedtke RR, Christopher DU, Filtz T, Rao AV, Molinoff PB and Ehrenkaufer RLE (1993) The use of $\left[{ }^{18} \mathrm{~F}\right]$ 4-fluorobenzyl iodide (FBI) in PET radiotracer synthesis: model alkylation studies and its application in the design of dopamine $D_{1}$ and $D_{2}$ receptor-based imaging agents. Nucl. Med. Biol., 20(6), 777-794.

Marazano C, Maziere M, Berger G and Comar D (1977) Synthesis of methyl iodide- ${ }^{11} \mathrm{C}$ and formaldehyde- ${ }^{11}$ C. Int. J. Appl. Radiat. Isot., 28, 49-54.

Maryanoff $\mathrm{BE}$ and Reitz $\mathrm{AB}$ (1989) The Wittig olefination involving phosphoryl stabilized carbanions. Stereochemistry, mechanism and selected synthesis aspects. Chem. Rev., 89, 863-867.

Mathieu, J, and Weill-Raynal J (1973) Formation of Carbon-Carbon Bonds, Vol. 1, 120145, George Thieme Publishers, Stuttgart, Germany.

More RD and Troughton JH (1972) Production of ${ }^{11} \mathrm{C}$ with a 3-MeV van de Graaf accelerator. Appl. Radiat. Isot., 23, 344-346. 
Muchowski M and Venuti MC (1980) Ortho functionalization of n-(tert-butoxy carbonyl)aniline. J. Org. Chem., 45, 4798-4801.

Mulholland GK, Toorongian SA, Jewett DM, Kilbourn MR( 1988) Polymer supported NCA nucleophilic radiofluorination: Rapid new synthesis of $\left[{ }^{18} \mathrm{~F}\right] \mathrm{FDG}$ with recovery of $\left[{ }^{18}\right.$ O]water. J. Nucl. Med., 229, 754-758.

Mulholland GK, Mangner TJ, Jewett DM and Kilbourn MR (1989) Polymer-supported nucleophilic radiolabelling reactions with $\left[{ }^{18} \mathrm{~F}\right]$ fluorine and $\left[{ }^{11} \mathrm{C}\right]$ cyanide ion on quaternary ammonium resins. J. Label. Cmpd. Radiopharm., 26 378-380.

Nader MW, Zeisler SK, Theobald A and Oberdorfer F (1997) Low temperature synthesis of no-carrier-added [ $\left.{ }^{11} \mathrm{C}\right]$ formaldehyde with metal hydrides and preparation of [1-

$\left.{ }^{11} \mathrm{C}\right] 1,2,3,4-t e t r a h y d r o-\beta$-carboline derivatives. Appl. Radiat. Isot., 49(12), 1599-1603.

Nagren K, Schoeps K-O, Halldin C., Swahn C-G and Farde L (1994) Selective synthesis of racemic $\left[1-{ }^{11} \mathrm{C}\right]$-labelled norepinephine, octopamine, norphenylephrine and phenylethanolamine using $\left[{ }^{11} \mathrm{C}\right]$ nitromethane. Appl. Radiat. Isot., 45, 515-521.

Neirinckx RD, Lambrecht RM and Wolf AP (1978) Cyclotron Isotopes and Radiopharmaceuticals-XXV: An anhydrous ${ }^{18} \mathrm{~F}$-fluorinating intermediate-trifluoromethyl hypofluorite. Int. J. Appl. Radiat. Isotope, 29, 323-327.

$\mathrm{Ng}$ JS, Katzenellenbogen JA and Kilbourn MR (1981) Aromatic fluorinations suitable for fluorine-18 labeling of estrogens. J. Org. Chem., 46, 2520-2526.

Nickles RJ, Daube ME and Ruth TJ (1984) An $\mathrm{O}_{2}$ target for the production of $\left[{ }^{18} \mathrm{~F}\right] \mathrm{F}_{2}$. Int. J. Appl. Radiat. Isot., 35, 117-122.

Nickles RJ, Gatley SJ, Votaw JR and Kornguth ML (1986) Production of reactive fluorine-18. Appl. Radiat. Isot. 37, 649-651.

Nozaki T, Iwamoto $\mathrm{M}$ and Ido $\mathrm{T}$ (1974) Yield of ${ }^{18} \mathrm{~F}$ for various reactions from oxygen and neon. Int. J. Appl: Radiat. Isotopes, 25, 393-396.

Oae S, Redvanly CS and Wolf AP (1968) Recoil labeling and selective radiation labeling. A novel synthesis of propanol-2,3- ${ }^{14} \mathrm{C}$. J. Label. Cmpd. Radiopharm. 4(1), 28-33.

Oberdorfer F, Hofinann E and Wolfgang M-B (1988a) Preparation of ${ }^{18} \mathrm{~F}$-labeled Nfluoropyridinium triflate, J. Label Cmpd. Radiopharm., 25(9), 999-1005.

Oberdorfer F, Hofmann E and Wolfgang M-B (1988b) Preparation of a new ${ }^{18} \mathrm{~F}$-labeled precursor: 1-[ $\left[{ }^{18} \mathrm{~F}\right]$ fluoro-2-pyridone. Appl. Radiat. Isot., 39(7), 685-688.

Ogren M, Hornfeldt K, Fasth KJ and Långström B(1995) $\left[{ }^{11} \mathrm{C}\right]$-Labelled polmer-bound Wittig reagents in the synthesis of $\left[^{11} \mathrm{C}\right]$-labelled aromatic alkanes. Appl. Radia. Isot., 47(8), 771-775. 
Oh S -J, Choe YS, Chi DY, Kim SE, Choi Y, Lee KH, Ha H -J and Kim B -T (1999) Reevaluation of 3-bromoproyl triflate as the precursor in the preparation of 3-

$\left[{ }^{18}\right.$ F]fluoropropyl bromide. Appl. Radiat. Isot: 51, 293-297.

O'Tauma LA, Phillips PC, Smith QR, Uno Y, Dannals RF, Wilson AA, Ravert HT, Loats S, Loats HA and Wagner HN, Jr. (1991) L-Methionine uptake by human cerebral cortex: maturation from infancy to old age. $J$. Nucl. Med., 32, 16-21.

Perris AG, Lane RO, Tong JY and Mathews JD (1974) The production of carbon-11 for medical uses by a tandem van de Graaf accelerator by the ${ }^{11} \mathrm{~B}(\mathrm{p}, \mathrm{n}){ }^{11} \mathrm{C}$ reaction. Int. $J$. Appl. Radiat. Isot., 25, 19-21.

Plenevaux A, Fowler JS, Dewey SL, Wolf AP and Guillaume M (1991) The synthesis of no-carrier-added D,L-4- $\left[{ }^{18} \mathrm{~F}\right]$ fluorodeprenyl via the nucleophilic aromatic substitution reaction. Appl. Radiat. Isot. 42, 121-128.

Pohlit HM, Erwin WR, Reynolds FL, Lemmon RM and Calvin M (1970) A low energy accelerator for hot atom chemical research. Rev. Sci. Instrum., 41, 1012-1020.

Ponchant M, Hinnen F, Demphel S and Crouzel C (1997) [ ${ }^{11}$ C]copper(I) cyanide: a new

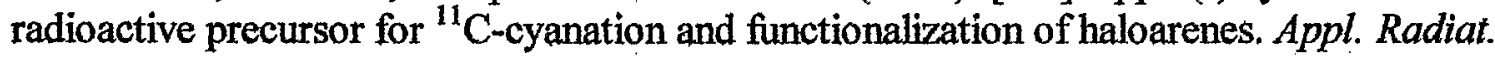
Isot., 48(6) 755-762.

Reiffers S, Vaalburg W., Wiegman T., Beerling H.D., Paans A.M.J. Woldring M.G. and Wijnberg H. (1979) ${ }^{11}$ C-Methyl lithium- a new synthetic tool in radiopharmaceutical chemistry. J. Label Cmpd. Radiopharm., 16, 56-59.

Reiffers S, Vaalburg W, Wiegman T, Wijnberg H and Woldring MG (1980) Carbon-11 labelled methyl lithium as a methyl donating agent: the addition to 17-Keto steroids. Int. J. Appl. Radiat. Isotopes, 31, 535-539.

Ritchie AIM (1968) The production of the isotopes ${ }^{11} \mathrm{C},{ }^{13} \mathrm{~N}$, and ${ }^{15} \mathrm{O}$ using the deuteron beam from a $3 \mathrm{MeV}$ van de Graaf accelerator. Nucl. Instr. Meth., 64, 181-183.

Roeda D and Westera G (1981) A UV induced on-line synthesis of ${ }^{11} \mathrm{C}$-phosgene and the preparatrion of some of its derivatives. J. Label. Cmpd. Radiopharm., 18, 11-15.

Roeda D, Crouzel C, and Van Zanten B (1978) Synthesis of ${ }^{11} \mathrm{C}$-urea for medical use. Radiochem. Radioanalytical Lett., 33, 175-176.

Rozen S (1988) Elemental fluorine as a legitimate reagent for selective fluorination of organic compounds. Accounts Chem. Res., 21, 307-312.

Rubottom GM and Kim C (1983) Preparation of methyl ketones by the sequential treatment of carboxylic acid with methyl lithium and chlorotrimethylsilane. J. Org. Chem., 48, 1550-1552. 
Ruth TJ and Wolf AP (1979) Absolute cross section for the production of ${ }^{18} \mathrm{~F}$ via the ${ }^{18} \mathrm{O}(\mathrm{p}, \mathrm{n}){ }^{18} \mathrm{~F}$ reaction. Radiochim. Acta., 26, 21-25.

Salmon E, Gregoire MC, Delfiore G and Lemaire C (1996) Combined study of cerebral glucose metabolism and $\left[{ }^{11} \mathrm{C}\right]$ methionine using positron emission tomography. $J$. Cerebral Blood Flow and Metabolism, 16, 399-405.

Satyamurthy N, Bida GT, Phelps ME and Barrio JR (1990a) N- $\left[{ }^{18}\right.$ F]Fluoro-Nalkylsulfonamides: novel reagents for mild and regioselective radiofluorination. Appl. Radiat. Isot., 41(8), 733-738.

Satyamurthy N, Barrio JR, Schmidt DG, Kammerer C, Bida GT and Phelps ME (1990b) Acid catalysed thermal decomposition of 1-aryl-3,3-diakyl-triazenes in the presence of nucleophiles. J. Org. Chem., 55, 4560-4565.

Schlyer DJ, Bastos $M$ and Wolf AP (1987) A rapid quantitative separation of fluorine-18 fluoride from oxygen-18 water. J. Nucl. Med. 28, 764-768.

Schlyer DJ, Bastos M, Alexoff D and Wolf AP (1990) Separation of $\left[{ }^{18} \mathrm{~F}\right]$ fluoride from $\left[{ }^{18} \mathrm{O}\right]$ water using anion exchange resin. Appl. Radiat. Isot., 41, 531-534.

Schoeps K-O, Stone-Elander S and Halldin C (1989) On-line synthesis of $\left[{ }^{11}\right.$ C]nitroalkanes. Appl. Radiat. Isot. 40, 261-262.

Schoeps K-O, Långström B, Stone-Elander S and Halldin C (1991) Synthesis of [1- $\left.{ }^{11} \mathrm{C}\right]-$ D-glucose and $\left[1-{ }^{11} \mathrm{C}\right]-\mathrm{D}$-mannose from on-line produced $\left[{ }^{11} \mathrm{C}\right]$ nitromethane. Appl. Radiat. Isot., 42, 877-883.

Schoeps K-O and Halldin C (1992) Synthesis of racemic $\left[\alpha-{ }^{11} \mathrm{C}\right]$ amphetamine and $[\alpha-$ ${ }^{11}$ C]phenethylamine from [ ${ }^{11}$ C]nitroalkanes. J. Label. Cmpd. Radiopharm. 31, 892-901.

Schoeps K-O, Halldin C, Nagren K, Swahn C-G, Karlsson P, Hall H and Farde L (1993) Preparation of $\left[1-{ }^{11} \mathrm{C}\right]$ dopamine, $\left[1-{ }^{11} \mathrm{C}\right] p$-tyramine and $\left[1{ }^{11} \mathrm{C}\right] m$-tyramine. Nucl. Med. Biol. 20, 669-678.

Schrobilgen GJ, Firnau G, Chirakal R and Garnett ES (1981) Synthesis of [ $\left.{ }^{18} \mathrm{~F}\right] \mathrm{XeF}_{2}$, a novel agent for the preparation of ${ }^{18} \mathrm{~F}$ radiopharmaceuticals. J. Chem. Soc. Chem. Comm., 198-199.

Shields AF, Lim K, Grierson J, Link J and Krohn KA (1990) Utilization of labeled thymidine in DNA synthesis: studies using PET. J. Nucl. Med., 31, 337-342.

Shields AF (1993) Measurement of tumor proliferation using $\left[{ }^{11} \mathrm{C}\right]$ thymidine and PET. in Clinical PET in Oncology, Proc. of the $2^{\text {nd }}$ Int'l Symp. On PET in Oncology, Sendia, Japan, 41-45. 
Shiue C - Y, Salvadori PA and Wolf AP(1982) A new synthesis of 2-deoxy-2-

[18F] fluoro-D-glucose from ${ }^{18}$ F-labeled acetyl hypofluorite, $J$. Nucl. Med., 23(10), 899903.

Shiue C -Y, Watanabe M, Wolf AP, Fowler JS and Salvadori P (1984) Application of the nucleophilic substitution reaction to the synthesis of no-carrier-added

$\left[{ }^{18} \mathrm{~F}\right]$ fluorobenzene and other ${ }^{18} \mathrm{~F}$-labeled aryl fluorides. J. Label Cmpds. Radiopharm., 21(6), 533-547.

Shiue C - Y, Fowler JS, Wolf AP, Watanabe M and Arnett CD (1985) Synthesis and specific activity determinations of NCA ${ }^{18} \mathrm{~F}$-labeled butyrophenone neuroleptics: benperidol, haloperidol, spiroperidol and pipamperone. J. Nucl. Med., 26, 181-186.

Shiue C - Y, Bai L -Q, Teng R and Wolf AP (1986a) Application of the nucleophilic substitution reactions to the synthesis of $\mathrm{NCA}^{18} \mathrm{~F}$-labeled radioligands. J. Label. Cmpds. Radiopharm., 23, 1038-1039.

Shiue C -Y, Fowler JS, Wolf AP, McPherson DW, Arnett CD and Zecca L (1986b) Nocarrier-added fluorine-18 labeled $\mathrm{N}$-methylspiroperidol: synthesis and biodistribution in mice. J. Nucl. Med. 27, 226-234.

Shiue C -Y, Bai L -Q, Teng R -R and Wolf AP (1987) Syntheses of no-carrier-added $\left[{ }^{18} \mathrm{~F}\right]$ fluoroalkyl halides and their application in the syntheses of $\left[{ }^{18} \mathrm{~F}\right]$ fluoroalkyl derivatives of neurotransmitter receptor active compounds. J. Labeled Cmpds. Radiopharm. 24(1), 55-64.

Silvester DJ (1976) Preparation of radiopharmaceuticals and labeled compounds using short-lived radionuclides," Radiochemistry, Vol. 3, The Chemical Society, Burlington House, London, 73-89.

Solin O and Bergman J (1986) Production of ${ }^{18} \mathrm{~F}-\mathrm{F}_{2}$ from ${ }^{18} \mathrm{O}_{2}$. J. Labeled Cmpd. Radiopharm. 23, 1202-1204.

Sood S, Firnau G, and Garnett ES (1983) Radiofluorination with xenon difluoride: a new high yield synthesis of $\left[{ }^{18} \mathrm{~F}\right.$ [2-fluoro-2-deoxy-D-glucose. Int. J. Appl. Radiat. Isat., 34(4), 743-745.

Steel CJ, Brown GD, Dowsett K, Turton DR, Luthra SK, Tochon-Danguy H, Waters SL, Price $\mathrm{P}$ and Brady F (1993) Synthesis of $2\left[{ }^{11} \mathrm{C}\right]$ thymidine from $\left[{ }^{11} \mathrm{C}\right]$ phosgene: a precursor for $2\left[{ }^{11} \mathrm{C}\right]$ thymidine. J. Label. Cmpd. Radiopharm., 32, 178-179.

Steel CJ, Brady F, Luthra SK, Brown G, Khan I, Poole KG, Sergis A, Jones T and Price PM (1999) An automated radiosynthesis of $2-\left[{ }^{11} \mathrm{C}\right]$ thymidine using anhydrous $\left[{ }^{11} \mathrm{C}\right]$ urea derived from [ ${ }^{11}$ C]phosgene. Appl. Radiat. Isot, 51, 377-388.

Straatman MG and Welch MJ (1975) A general method for labeling proteins with carbon-11. J. Nucl. Med., 16, 425-428. 
Straatman MG, Schlyer DJ and Chasko DJ (1982) Synthesis of ${ }^{18} \mathrm{~F}$-fluorine gas from nocarrier-added ${ }^{18}$ F-HF. J. Label Cmpd. Radiopharm., 19 1373-1377.

Strauss LG and Conti PS (1991) Application of PET in clinical oncology. J. Nucl. Med., 32, 623-631.

Studenov AR, Berridge MS, Soloviev DV, Matarrese M and Todde S (1999) High yield synthesis of $\left[{ }^{11} \mathrm{C}\right]$-acetone through selective quenching of methyl lithium. Nucl. Med. Biol., 26, 431-435.

Suehiro M, Shiue C -Y, Gonzalez C and Dembowski B (1995) Synthesis of $\left[{ }^{11} \mathrm{C}\right]$ methanethiol, a precursor for S-methylations. J. Label. Cmpd. Radiopharm., 37, $109-113$

Teng R -R, Bai L -Q, Shiue C -Y, Dewey SL, Arnett CD, Wolf AP and Hitzemann RJ (1990) The utility of $1-\left[{ }^{18} \mathrm{~F}\right]$ fluoro-3-iodopropane for the synthesis of certain dopamine D-1 and benzodiazepine receptor radioligands. Nucl. Med. \& Biol. 17(8), 811-817.

Tewson TJ and Welch MJ (1980) Preparation and preliminary biodistributuion of NCA fluorine-18 fluoroethanol. J. Nucl. Med. 21, 559-564.

Vaalburg W and Paans AMJ (1983) Short-lived positron emitting radionuclides., in Radionuclides Production, Vol. II, 47-101, CRC Series in Radiotracers in Biology and Medicine, Helus F, Colombetti LG, (eds.), CRC Press, Inc., Boca Raton, Florida.

Vaidyanathan $\mathrm{G}$ and Zalutsky $\mathrm{M}$ (1992) Labeling proteins with fluorine-18 using $\left[{ }^{18} \mathrm{~F}\right]-$ N-succinimidyl-4-fluorobenzoate. Nucl. Med. Biol., 19(3), 275-281.

Van der Borght T, Lambotte LE, Pauwels SA and Dive CC (1990) Uptake of thymidine labeled on carbon 2: a potential index of liver regeneration by PET. Hepatology, 12, 113118.

Van der Borght T, Labar D, Pauwels S and Lambotte L (1991) Production of [2-

${ }^{11}$ C]thymidine for quantification of cellular proliferation with PET. Appl. Radiat. Isot., 42, 103-104.

Vera Ruiz H (1988) report of an International Atomic Energy Agency's Consultant's Meeting on fluorine-18: reactor production and utilization. Appl. Radiat. Isot., 39, 31-42.

Visser TJ, van der Wouden EA, van Waarde A, Doze P, Elsinga PH and Vaalburg W (2000) Synthesis and biodistribution of $\left[{ }^{11} \mathrm{C}\right]$ procaterol a $\beta_{2}$-adrenoceptor agonist for positron emission tomography. Appl. Radiat. Isot., 52(4), 857-863.

Wagner R, Stöcklin G and Schaak W (1981) Production of carbon-11 labelled methyl iodide by direct recoil synthesis. J. Label. Cmpd. Radiopharm., 18, 189-192.

Wagner H.N, Burns H.D, Dannals RF, Wong DF, Långström B, Duelfer T, Frost J, Ravert HT, Links JM, Rosenbloom HB, Lucas SH, Kramer AV and Kuhar M (1983) 
Imaging dopamine receptors in the human brain by positron tomography. Science, 221, 1264-1266.

Welch MJ and Ter-Pogossian MM(1968) The preparation of short half-lived radioactive gases for medical studies. Radiat. Res., 36, 580-589.

Westerberg $\mathrm{G}$ and Långström B (1997) On-line production of $\left[{ }^{11} \mathrm{C}\right]$ cyanogen bromide. Appl. Radiat. Isot. 48(4), 459-461.

Westerberg G, Långström B (1993) Synthesis of $\left[{ }^{11} \mathrm{C}\right]$ - and $\left[{ }^{13} \mathrm{C}\right]$ cyanogens bromide: useful labeling precursors. Acta. Chem. Scand. 47, 974-978.

Wilkinson $\mathrm{DH}(1955){ }^{12} \mathrm{C}(\mathrm{d}, \mathrm{n}){ }^{11} \mathrm{C}$ groundstate and ${ }^{12} \mathrm{C}(\mathrm{d}, \mathrm{t}){ }^{11} \mathrm{C}$ up to $\mathrm{E}_{\mathrm{d}}=20 \mathrm{MeV}$. Phys. Rev., 100, 32-38.

Wilkinson JA (1992) Recent advances in the selective formation of the C-F bond, Chem. Rev., 92, 505-519.

Winchell HS, Wells DK, Lamb JF, Beavdry SB (1976) Process for preparing fluorine-18. U.S. Patent 3,981,769.

Winstead MB, Lamb JF and Winchell HS (1973) Relationship of chemical structure to in vivo scintigraphic distribution patterns of ${ }^{11} \mathrm{C}$ compounds I: ${ }^{11} \mathrm{C}$-carboxylates. J. Nucl. Med., 14, 747-750.

Wolf AP (1960) Labeling of organic compounds by recoil methods. Ann. Rev. Nucl. Sci., 10, 285-290.

Wolf AP, Christman DR, Fowler JS and Lambrecht RM (1973) Synthesis of radiopharmaceuticals and labeled compounds utilizing short-lived isotopes. in Radiopharmaceuticals and Labeled Compounds, Vol I, IAEA, Vienna, IAEA-SM$171 / 30,345-351$.

Wolf AP and Redvanly CS (1977) Carbon-11 and radiopharmaceuticals. Int. J. Appl. Radiat. Isot., 28, 29-48.

Wolfgang R, Pratt T and Rowland FS (1956) Production of labeled organic material with accelerated tritium. J. Am. Chem. Soc., 78, 5132-5138.

Zheng L and Berridge MS(2000) Synthesis of $\left[{ }^{18} \mathrm{~F}\right]$ fluoromethyl iodide, a precursor for fluoromethylation of radiopharmaceuticals. Appl. Radiat. Isot. 52, 55-61. 
Table 1. Physical Properties of the Short-Lived Positron Emitters

\begin{tabular}{lccccl}
\hline \multicolumn{1}{c}{ Isotope } & $\begin{array}{c}\text { Half-life } \\
\text { (min) }\end{array}$ & $\begin{array}{c}\text { Specific } \\
\text { Activity }^{\mathrm{n}} \\
(\mathrm{Ci} / \mathrm{mmol})\end{array}$ & $\begin{array}{c}\text { Maximum } \\
\text { Energy } \\
(\mathrm{MeV})\end{array}$ & $\begin{array}{c}\text { Range }(\mathrm{mm}) \\
\text { in Water }^{\mathrm{b}}\end{array}$ & $\begin{array}{c}\text { Decay } \\
\text { Product }\end{array}$ \\
\hline Fluorine-18 & 110 & $1.71 \times 10^{6}$ & 0.635 & 2.4 & Oxygen-18 \\
Carbon-11 & 20.4 & $9.22 \times 10^{6}$ & 0.96 & 4.1 & Boron-11 \\
Nitrogen-13 & 9.96 & $1.89 \times 10^{7}$ & 1.19 & 5.4 & Carbon-13 \\
Oxygen-15 & 2.1 & $9.08 \times 10^{7}$ & 1.72 & 8.2 & Nitrogen-15 \\
\hline
\end{tabular}

a. Theoretical maximum specific activity; in practice, specific activities are typically 5000 times lower because of unavoidable dilution with the stable element.

b. Maximum linear range. 
Table 2. Nuclear Reactions for Producing Carbon-11

\begin{tabular}{|c|c|c|c|c|c|}
\hline Particle & Reaction & $\begin{array}{l}\text { Q-Value } \\
\text { (MeV) }\end{array}$ & $\begin{array}{l}\text { Threshold } \\
\text { (MeV) }\end{array}$ & $\begin{array}{c}\text { Cross } \\
\text { Section } \\
\text { (mb) }\end{array}$ & Reference \\
\hline$\gamma$ & ${ }^{12} \mathrm{C}(\gamma, n){ }^{11} \mathrm{C}$ & -18.7 & 18.7 & 4 & Hylten, 1970 \\
\hline $\mathrm{p}$ & ${ }^{11} \mathrm{~B}(\mathrm{p}, \mathrm{n}){ }^{11} \mathrm{C}$ & -2.8 & 3.0 & 100 & $\begin{array}{l}\text { Hintz and } \\
\text { Ramsey, } 1952\end{array}$ \\
\hline $\mathrm{p}$ & ${ }^{10} \mathrm{~B}(\mathrm{p}, \gamma){ }^{11} \mathrm{C}$ & & 0 & & $\begin{array}{l}\text { Crane and } \\
\text { Lauritsen, } 1934\end{array}$ \\
\hline $\mathrm{p}$ & ${ }^{12} \mathrm{C}(\mathrm{p}, \mathrm{pn}){ }^{11} \mathrm{C}$ & -18.7 & 20.3 & 100 & $\begin{array}{l}\text { Aamodt et al., } \\
1952\end{array}$ \\
\hline $\mathrm{p}$ & ${ }^{14} \mathrm{~N}(p, \alpha){ }^{11} \mathrm{C}$ & 2.9 & 3.1 & 250 & $\begin{array}{l}\text { Epherre and } \\
\text { Seide, } 1971\end{array}$ \\
\hline d & ${ }^{10} \mathrm{~B}(\mathrm{~d}, \mathrm{n}){ }^{11} \mathrm{C}$ & 6.5 & 0 & 180 & $\begin{array}{l}\text { Brill and Sumin, } \\
1960\end{array}$ \\
\hline d & ${ }^{11} \mathrm{~B}(\mathrm{~d}, 2 \mathrm{n}){ }^{11} \mathrm{C}$ & -5.0 & 5.9 & 48 & $\begin{array}{l}\text { Brill and } \\
\text { Sumin, } 1960\end{array}$ \\
\hline d & ${ }^{12} \mathrm{C}(\mathrm{d}, \mathrm{p} 2 \mathrm{n}){ }^{11} \mathrm{C}$ & -20.9 & 24.4 & 61 & Wilkinson, 1955 \\
\hline${ }^{3} \mathrm{He}$ & ${ }^{9} \mathrm{Be}\left({ }^{3} \mathrm{He}, \mathrm{pn}\right){ }^{11} \mathrm{C}$ & 7.6 & 0 & 113 & $\begin{array}{l}\text { Hahn and } \\
\text { Ricci, } 1966\end{array}$ \\
\hline${ }^{3} \mathrm{He}$ & ${ }^{10} \mathrm{~B}\left({ }^{3} \mathrm{He}, \mathrm{pn}\right){ }^{11} \mathrm{C}$ & 1.2 & 0 & 285 & Brill, 1965 \\
\hline${ }^{3} \mathrm{He}$ & ${ }^{11} \mathrm{~B}\left({ }^{3} \mathrm{He}, \mathrm{p} 2 \mathrm{n}\right){ }^{11} \mathrm{C}$ & -1.8 & 2.3 & $35^{\mathrm{a}}$ & \\
\hline${ }^{3} \mathrm{He}$ & ${ }^{12} \mathrm{C}\left({ }^{3} \mathrm{He},{ }^{4} \mathrm{He}\right){ }^{11} \mathrm{C}$ & 1.9 & 0 & 260 & Brill, 1965 \\
\hline${ }^{4} \mathrm{He}$ & ${ }^{16} \mathrm{O}\left({ }^{4} \mathrm{He}, 2^{4} \mathrm{He}\right){ }^{11} \mathrm{C}$ & -5.3 & 6.3 & 49 & Brill, 1965 \\
\hline${ }^{4} \mathrm{He}$ & ${ }^{9} \mathrm{Be}\left({ }^{4} \mathrm{He}, 2 \mathrm{n}\right){ }^{11} \mathrm{C}$ & -13.0 & $18.8^{\circ}$ & 17 & $\begin{array}{l}\text { Brill and } \\
\text { Sumin, } 1960\end{array}$ \\
\hline${ }^{4} \mathrm{He}$ & ${ }^{10} \mathrm{~B}\left({ }^{4} \mathrm{He}, \mathrm{p} 2 \mathrm{n}\right){ }^{11} \mathrm{C}$ & -19.6 & 27.4 & $50^{\mathrm{a}}$ & \\
\hline${ }^{4} \mathrm{He}$ & ${ }^{11} \mathrm{~B}\left({ }^{4} \mathrm{He}, \mathrm{p} 3 \mathrm{n}\right){ }^{11} \mathrm{C}$ & -31.1 & 42.4 & $17^{\mathrm{a}}$ & \\
\hline${ }^{4} \mathrm{He}$ & ${ }^{12} \mathrm{C}\left({ }^{4} \mathrm{He},{ }^{4} \mathrm{He}, \mathrm{n}\right){ }^{11} \mathrm{C}$ & -18.7 & 24.9 & 48 & $\begin{array}{l}\text { Lindner and } \\
\text { Osbourne, } 1953\end{array}$ \\
\hline
\end{tabular}

a. Theoretical cross-section calculated according to statistical model. (Vaalburg and Paans, 1983) 
Table 3. Nuclear Reactions For The Production of Fluorine-18

\begin{tabular}{|c|c|c|c|c|}
\hline Particle & Reaction & $\begin{array}{l}\text { Q-Value } \\
\text { (MeV) }\end{array}$ & $\begin{array}{l}\text { Threshold } \\
\text { (MeV) }\end{array}$ & Reference \\
\hline$t$ & ${ }^{16} \mathrm{O}(\mathrm{t}, \mathrm{n})^{18} \mathrm{~F}$ & 1.270 & 0 & Vera Ruiz, 1988 \\
\hline${ }^{3} \mathrm{He}$ & ${ }^{16} \mathrm{O}\left({ }^{3} \mathrm{He}, \mathrm{p}\right){ }^{18} \mathrm{~F}$ & 2.003 & 0 & $\begin{array}{l}\text { Nozaki et al., 1974; } \\
\text { Fitschen } \text { et al., 1977 }\end{array}$ \\
\hline${ }^{3} \mathrm{He}$ & ${ }^{16} \mathrm{O}\left({ }^{3} \mathrm{He}, \mathrm{n}\right){ }^{18} \mathrm{Ne} \rightarrow{ }^{18} \mathrm{~F}$ & -3.196 & 3.795 & $\begin{array}{l}\text { Nozaki et al., 1974; } \\
\text { Knust and }\end{array}$ \\
\hline$\alpha$ & ${ }^{16} \mathrm{O}(\alpha, \mathrm{d}){ }^{18} \mathrm{~F}$ & -18.544 & 23.180 & $\begin{array}{l}\text { Machulla, } 1983 \\
\text { Clark and } \\
\text { Silvester, } 1966\end{array}$ \\
\hline$\alpha$ & ${ }^{16} \mathrm{O}(\alpha, 2 \mathrm{n}){ }^{18} \mathrm{Ne} \rightarrow{ }^{18} \mathrm{~F}$ & -23.773 & 29.716 & Nozaki et al., 1974 \\
\hline $\mathrm{d}$ & ${ }^{20} \mathrm{Ne}(\mathrm{d}, \alpha)^{18} \mathrm{~F}$ & 2.796 & 0 & $\begin{array}{l}\text { Helus et al., 1979; } \\
\text { Casella et al., 1980; }\end{array}$ \\
\hline${ }^{3} \mathrm{He}$ & ${ }^{20} \mathrm{Ne}\left({ }^{3} \mathrm{He}, \alpha \mathrm{p}\right){ }^{18} \mathrm{~F}$ & -2.697 & 3.102 & $\begin{array}{l}\text { Backhausen et al., } \\
1981\end{array}$ \\
\hline${ }^{3} \mathrm{He}$ & ${ }^{20} \mathrm{Ne}\left({ }^{3} \mathrm{He}, \alpha \mathrm{n}\right){ }^{18} \mathrm{Ne} \rightarrow{ }^{18} \mathrm{~F}$ & -7.926 & 9.115 & $\begin{array}{l}\text { Backhausen, et al., } \\
\text { 1981; Crouzel and } \\
\text { Comar. } 1978\end{array}$ \\
\hline $\mathrm{p}$ & ${ }^{18} \mathrm{O}(\mathrm{p}, \mathrm{n}){ }^{18} \mathrm{~F}$ & -2.436 & 2.571 & $\begin{array}{l}\text { Ruth and Wolf,1979; } \\
\text { Nickles et al. } 1984\end{array}$ \\
\hline
\end{tabular}


Keyword Index

Page

$\left[{ }^{11} \mathrm{C}\right]$ Carbon oxides

4-6

$\left[{ }^{11} \mathrm{C}\right]$ Carbon dioxide

4,5

$\left[{ }^{11} \mathrm{C}\right]$ Carbon monoxide

5,6

$\left[{ }^{11} \mathrm{C}\right]$ Methane

$\left[{ }^{11} \mathrm{C}\right]$ Cyanides

6-9

$\left[{ }^{11} \mathrm{C}\right] \mathrm{Hyd}$ drogen cyanide

6,7

$\left[{ }^{11} \mathrm{C}\right]$ Copper(I) cyanide 7,8

$\left[{ }^{11} \mathrm{C}\right]$ Cyanogen bromide

9

$\left[{ }^{11} \mathrm{C}\right]$ Cyanates

$\left[{ }^{11} \mathrm{C}\right]$ Thiocyanates

$\left[{ }^{11} \mathrm{C}\right]$ Cyanamides

$\left[{ }^{11} \mathrm{C}\right]$ Methylating agents

9-12

$\left[{ }^{11} \mathrm{C}\right]$ Methyl iodide

$\left.{ }^{11} \mathrm{C}\right]$ Methyl lithium

$\left[{ }^{11} \mathrm{C}\right]$ Methyl triflate

$\left[{ }^{11} \mathrm{C}\right]$ Methyl magnesium iodide

11,12

$\left[{ }^{11} \mathrm{C}\right]$ Formaldehyde

$\left[{ }^{11} \mathrm{C}\right]$ Phosgene

12-14

$\left[{ }^{11} \mathrm{C}\right]$ Alkyl iodides

14,15

$\left[{ }^{11} \mathrm{C}\right]$ Nitro alkanes

15,16

$\left.{ }^{11} \mathrm{C}\right]$ Alkyl thiols

16,17

$\left[{ }^{11} \mathrm{C}\right]$ Urea

$\left[{ }^{11} \mathrm{C}\right]$ Acetone

$\left.{ }^{11} \mathrm{C}\right]$ Phosphonium salts

18,19

$\left[{ }^{18} \mathrm{~F}\right]$ Fluorine gas

$\left[{ }^{18} \mathrm{~F}\right]$ Trifluoromethyl hypofluorite

$\left[{ }^{18} \mathrm{~F}\right]$ Acetyl hypofluorite

21,22

$\left[{ }^{18} \mathrm{~F}\right]$ Xenon difluoride

$\left[{ }^{18} \mathrm{~F}\right]-\mathrm{N}$-Fluoropyridinium triflate

$\left[{ }^{18} \mathrm{~F}\right]-1-$-Fluoro-2-pyridone 
$\left[{ }^{18} \mathrm{~F}\right]-\mathrm{N}$-Fluoro-N-alkylsulfonamides

$\left[{ }^{18} \mathrm{~F}\right]$ Fluorobenzene

$\left[{ }^{18} \mathrm{~F}\right]$ Fluoride ion 25-27

$\left[{ }^{18}\right.$ F]Fluoroalkylating agents : $\quad 27-31$

$\left[{ }^{18} \mathrm{~F}\right]$ Fluoromethyl bromide $\quad 28$

$\left[{ }^{18} \mathrm{~F}\right]$ Fluoromethyl iodide $\quad 28,29$

$\left[{ }^{18}\right.$ F]Fluoroalkyl tosylates . 30

$\left[{ }^{18} \mathrm{~F}\right]$ Fluoropropyl bromide $\quad 31$

$\left[{ }^{18} \mathrm{~F}\right]$ Fluoropropyl iodide $\quad 31$

$\left[{ }^{18} \mathrm{~F}\right]$ Acylating agents $\quad 31-32$

$\left[{ }^{18} \mathrm{~F}\right]$ Fluorocarboxylic acids $\quad 31-32$

$\left[{ }^{18} \mathrm{~F}\right]$ Fluoropropionic acid methyl ester 31

$\left[{ }^{18}\right.$ F]Fluoroacetic acid 31

$\left[{ }^{18} \mathrm{~F}\right]$ Fluorobenzoic acid 31

$\left[{ }^{18} \mathrm{~F}\right]$-N-succinimidyl 8-(4-fluorobenzyl)amino substrates $\quad 32$

$\left[{ }^{18} \mathrm{~F}\right]-\mathrm{N}$-succinimidyl 4-(fluoromethyl)benzoate 32-37

$\left[{ }^{18}\right.$ F]Fluorobenzaldehyde $\quad 32$

$\left[{ }^{18} \mathrm{~F}\right]$ Fluorobenzyl alcohols 33

$\left[{ }^{18}\right.$ F]Fluorobenzyl halides $\quad 33-35$

$\left[{ }^{18}\right.$ F]Fluorobenzylsulfonate esters $\quad 36,37$

$\left[{ }^{18}\right.$ F]Fluorohalobenzene $\quad 36,37$

$\left[{ }^{18} \mathrm{~F}\right]$ Fluorobromobenzene $\quad 37$

$\left[{ }^{18}\right.$ F]Fluoroiodobenzene $\quad 37$

$\left[{ }^{18}\right.$ F]Fluoroaryl ketones $\quad 37$

$\left[{ }^{18}\right.$ F]Fluoroacetophenone $\quad 37$

$\left[{ }^{18}\right.$ F]Fluorophenylacyl bromide $\quad 37$ 